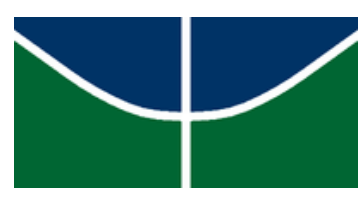

Universidade de Brasília

Instituto de Psicologia

Programa de Pós-graduação em Psicologia Clínica e Cultura

Subjetivação, Música e Temporalidades

Vítor Luiz Neto

Brasília, DF 
Universidade de Brasília

Instituto de Psicologia

Programa de Pós-graduação em Psicologia Clínica e Cultura

Subjetivação, Música e Temporalidades

\author{
Vítor Luiz Neto
}

Dissertação apresentada ao Instituto de Psicologia da Universidade de Brasília como requisito parcial para a obtenção do título de Mestre em Psicologia Clínica e Cultura

Orientadora: Dra. Terezinha de Camargo Viana

Coorientadora: Dra. Márcia Teresa Portela de Carvalho

Brasília, DF 


\author{
Universidade de Brasília \\ Instituto de Psicologia \\ Programa de Pós-graduação em Psicologia Clínica e Cultura
}

\title{
Subjetivação, Música e Temporalidades
}

\author{
Vítor Luiz Neto
}

Dissertação apresentada ao Instituto de Psicologia da Universidade de Brasília como requisito parcial para a obtenção do título de Mestre em Psicologia Clínica e Cultura

Orientadora: Dra. Terezinha de Camargo Viana

Coorientadora: Dra. Márcia Teresa Portela de Carvalho

Banca Examinadora:

Professora Dra. Márcia Teresa Portela de Carvalho (UnB - Membro efetivo)

Professora Dra. Priscilla Melo Ribeiro de Lima (UFG - Membro externo)

Professora Dra. Daniela Scheinkman Chatelard (UnB - Suplente)

Brasília, DF 
Aos meus pais,

Maysa Rosa Neto Luiz e Wilton Luiz, por tornarem tudo uma fresta de possibilidade. 


\section{Agradecimentos}

Aos meus pais, por me darem o espaço necessário às escolhas, pela disposição à dúvida nos momentos em que eu não sabia para onde ir, pelo intenso suporte e por abdicarem, em saudade, a minha presença nos seus cotidianos.

Aos meus irmãos, Leíza e Gustavo, que, cada um de seu modo, meu auxiliaram durante este trajeto, seja pela troca de experiências sobre o mundo da pesquisa, pela torcida constante e pela confiança em meu potencial.

Aos professores da graduação na Universidade Federal de Goiás, de Catalão, em especial à Tânia e ao Maurício por sempre me lembrarem qual era o meu lugar, à Renata e à Emilse pelo apoio e curiosidade sobre meu trabalho, à Elzilaine pela troca de saberes acerca da subjetividade e da contemporaneidade, à Karine e ao Fernando por me mostrarem o dever e a responsabilidade em desnaturalizar o mundo.

Aos meus amigos de Catalão por sempre me darem apoio e por impulsionarem ainda mais os meus caminhos, pela convivência, pelas conversas sobre a vida e sobre meu tema, pela vontade em saber sobre meu trabalho. Aos amigos de Brasília, os novos e os que já estão há mais tempo, por me acolherem nesta cidade estranha de gente esquisita e por me fazerem sentir em casa.

Ao meu primo Marcos por me acolher num primeiro momento durante o processo seletivo e no começo de tudo. À Cida e à Isabelle, minha segunda família, com quem dividi a vida nestes últimos tempos, por me levarem para dentro de sua casa, pelas alegrias e dificuldades, pelas novidades apresentadas e pelo companheirismo e amor.

Aos professores do Programa de Pós-graduação em Psicologia Clínica e Cultura da Universidade de Brasília por compartilharem conhecimentos que eu jamais pensei que pudesse alcançar.

Aos colegas do Laboratório de Psicanálise dos Processos de Subjetivação pelas discussões, pelos trabalhos compartilhados, pelas ideias e sugestões tão válidas, pelas risadas e pela ajuda mútua. À Michele e ao André, pela troca de incertezas e angústias e por estenderem nossa relação para além da universidade.

À professora Terezinha de Camargo Viana por ter aceito minha proposta de pesquisa e por me fazer pensar um assunto tão vasto quanto o tempo. Obrigado por receber meus devaneios, filtrar aquilo que era importante e rir do que não fazia o menor sentido. Obrigado pelos encontros sempre divertidos, leves, requintados e singelos ao mesmo tempo. Obrigado por produzir conosco conhecimentos de forma séria, firme e também liberta, o que é uma capacidade de poucos. A admiração e o grande respeito vindo por parte de seus colegas e amigos não são em vão.

À Márcia Portela por aceitar, com grande disponibilidade e entusiasmo, a coorientação deste trabalho, pelas reuniões sempre aconchegantes e produtivas, pela aposta no meu tema e objeto de estudo, por ouvir o que eu queria dizer, mesmo que nas entrelinhas ou quando eu não sabia como expressar. Me sinto muito grato e honrado em trabalhar com uma pessoa tão competente em sua escuta e interpretação das relações. 
Às professoras Daniela Chatelard e Priscilla Lima por aceitarem participar da banca examinadora desta dissertação. Tenho certeza que trarão sugestões e construções importantes para este trabalho, bem como para produções futuras.

À Universidade de Brasília e ao Instituto de Psicologia pela possibilidade institucional de realização de minha pesquisa, no meu tema de interesse. Por misturar concreto e natureza, por trazer paz e inquietação, pela energia transmitida através de sua história e de seus corredores, pelos espaços inacreditáveis que ali se encontram, pela diversidade de seus sujeitos.

Ao CNPq pelo incentivo financeiro que fez sustentar este trabalho e por me fazer reconhecer ainda mais a importância da pesquisa. 
Batidas na porta da frente é o tempo Eu bebo um pouquinho pra ter argumento Mas fico sem jeito, calado, ele ri Ele zomba do quanto eu chorei Porque sabe passar e eu não sei

Um dia azul de verão, sinto o vento Há folhas no meu coração é o tempo Recordo um amor que perdi, ele ri Diz que somos iguais, se eu notei Pois não sabe ficar e eu também não sei

E gira em volta de mim, sussurra que apaga os caminhos Que amores terminam no escuro sozinhos

Respondo que ele aprisiona, eu liberto Que ele adormece as paixões, eu desperto

E o tempo se rói com inveja de mim Me vigia querendo aprender Como eu morro de amor pra tentar reviver

No fundo é uma eterna criança que não soube amadurecer Eu posso, ele não vai poder me esquecer

Resposta ao Tempo - Aldir Blanc e Cristóvão Bastos 


\section{Resumo}

Esta dissertação trabalha o entrelaçamento entre tempo e processos de subjetivação. O principal objetivo deste trabalho é entender e problematizar como se dá histórica, social e culturalmente as percepções temporais no sujeito, reconhecendo a vulnerabilidade humana frente ao real do tempo. Para isso, utilizou-se da Psicanálise, das Ciências Sociais, da História e da Arte, em específico as músicas da cantora baiana Pitty, para reconhecer possíveis inscrições destas percepções. Neste sentido, o tempo é entendido enquanto um símbolo social que não diz apenas de uma construção humana e nem exclusivamente de um dado do transcorrer natural. O tempo é, por isso, um processo de subjetivação, a própria subjetividade, a partir do desenvolvimento de determinados processos históricos e sociais. Num primeiro momento são resgatadas percepções acerca do assunto do tempo em alguns contextos históricos, perpassando pelas idades Antiga e Média até reconhecer o caráter disciplinatório e onipresente que o tempo adquire na vida humana a partir da Modernidade e, consequentemente, nas sociedades ocidentais mais atuais. Percebe-se a transição de um tempo externo, da natureza ou divino, para um tempo interno, a partir da emergência de um sujeito histórico dotado de interioridade. Este movimento se deu através de transformações socioeconômicas que propiciaram a configuração da existência humana como tempo. A partir disto, em uma segunda parte, buscamos entender a diferenciação do caráter social e cultural do tempo ao longo do processo civilizatório, o que permite trabalhar mais detalhadamente a constituição temporal do psiquismo e a relação entre tempo e pulsionalidade, que obedecem a formas culturais de satisfação. Neste momento, o tempo não só exige satisfação mas passa a ser confundido enquanto próprio objeto de satisfação, uma vez que as determinações sociais e culturais modelam as percepções subjetivas e as formas de existências pautadas em um tempo que deve ser buscado e que ainda não está, através da ação. O tempo entrelaçado ao desejo gera e é sintoma, já que leva o sujeito a encarar de frente não só o seu aspecto simbólico, mas também o seu real, aquilo que não se pode representar sobre o tempo, sobretudo, o encontro com o fim, reconhecendo a vulnerabilidade humana frente ao real do tempo. Estas discussões permitem, no terceiro momento deste trabalho, a aventura através da Arte como forma de dar um significado às experiências subjetivas acerca do tempo enquanto desejo e sintoma. Sendo assim, através das músicas de Pitty, reconhecemos um sujeito que sofre por um tempo que exige aproveitamento e que se entrelaça com o desejo humano, além de deixarem explícitas formas vigentes do tempo, que se alternam entre aceleração e desaceleração, pautadas pela noção do eterno presente que vangloria o agora como único momento de se fazer a vida. Reconhecemos também, através das expressões da cantora, uma necessidade de suspender o tempo para se aproveitar o momento de forma significativa e o encontro com o outro e consigo mesmo, fundamentais para se criar uma resistência às formas de vida pautadas nas políticas do tempo atuais.

Palavras-chave: Tempo; processos de subjetivação; eterno presente; resistência; Pitty. 


\begin{abstract}
This dissertation works the interlacement among time and processes of subjectivity. This work's main objective is understand and problematize how is historical, social and culturally the subject's temporal perceptions. It was used Psychoanalysis, Social Sciences, History and Art, in particular the songs of the Brazilian singer Pitty, to recognize possible inscriptions of these perceptions. In this sense, time is understood as a social symbol that is not just a human construction and not only a data of the natural course. Time is, therefore, a process of subjectivity, the subjectivity itself, from the certain historical and social processes' development. At first, are redeemed some perceptions about the time issue in some historical contexts, passing by the Ancient and Middle ages to recognize the disciplinarian and omnipresent character that time acquires in human life from the modernity and, consequently, in current Western societies. We see the transition from an external time, natural or divine, to an internal time, from the historical subject's emergence, provided with interiority. This move was made through socio-economic transformations that have led the human existence's shape as time. From this, in a second part, we sought to understand the social and cultural character's differentiation of time over the civilizing process, which allows working in details the psyche's temporal constitution and the relation among time and instincts, which obey satisfaction's cultural forms. This way, the time requires not only joy but becomes an own satisfaction object, once the social and cultural determinations shape the subjective perceptions and existence's forms, guided at a time who is not reached yet and should be sought through action. Time interlaced as desire and satisfaction makes and is symptom, as it takes the subject to face not only its symbolic aspect, but also its real, what cannot be represented about the time, above all, the encounter with the death, recognizing human's vulnerability toward real's time. These discussions allow, at the third part of this work, the adventure through Art as a way to give meaning to subjective experiences about time as desire and symptom. Thus, through Pitty songs, we recognize a subject who suffers for a time that requires utilization and that interlaces with human desire, as well as explains current time forms, alternating between acceleration and deceleration, guided by the eternal present's notion, which boasts the "right now" as the only time to make a living. We also recognize, through the singer's expressions, a need to suspend the time to seize the moment significantly and the encounter with others and with oneself, something fundamental to create a resistance to forms of life guided by the current time policies.
\end{abstract}

Keywords: Time; process of subjectivity; eternal present; resistance; Pitty. 


\section{Sumário}

"Primeiro, Os Aniversários": introdução.

Capítulo I: "Esse mundo já faz muito tempo": o tempo atravessando a história 20

1.1."Espíritos só passam por aqui": o tempo de fora da antiguidade e da idade média. 22

1.2."Busquei dentro de mim os meus lares": o tempo de dentro da modernidade 26

1.2.1. "Não sinhô, sim sinhô": a disciplinarização do e ao tempo. 27

1.2.2. "Cada um em seu casulo, em sua direção": a subjetividade privatizada...... 29

1.2.3. "Não deixe nada pra depois, não deixe o tempo passar": tempo do capital........34

1.2.4. “Quem partiu a Terra ao meio?”: a ruptura dos tempos................................... 41

1.3.“O futuro é o presente, e o presente já passou”: novos tempos, tempos de quê?. 45

Capítulo II: "Mudaram os horários, hábitos, lugares": a constituição temporal na relação sujeito e cultura. .53

2.1. "Mas pare e perceba como o seu dia-a-dia mudou": do tempo como símbolo social....... 58

2.2. "Não me leve agora": o sentido existencial como determinação temporal......................... 62

2.3. "Foi sem hora pra voltar": um sujeito temporal à espera da satisfação............................ 70

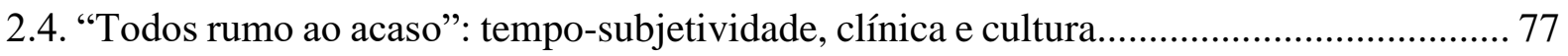

2.5. "Tenho tanto o que fazer": a ação como resposta à vulnerabilidade. 81

Capítulo III: "Com toda beleza e abominação": o tempo-subjetividade na música de Pitty.... 91

3.1. "Resistindo a me dissolver", sangro e suspendo - uma oitava abaixo e outra acima........ 96

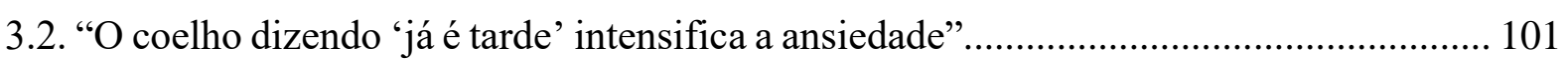

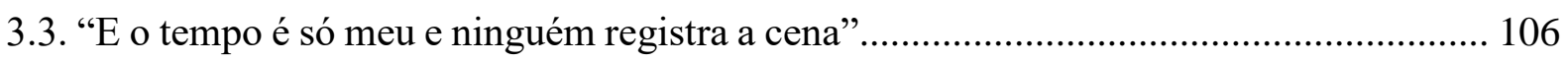

3.4. "Por baixo ainda é serpente e devora a cauda pra recomeçar"...................................... 109

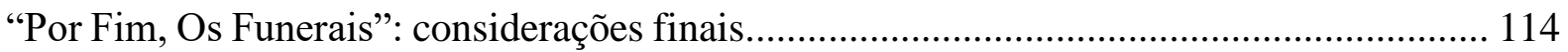

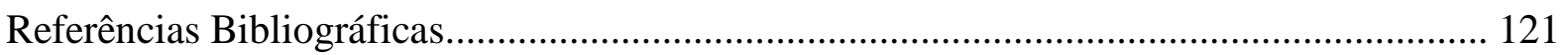

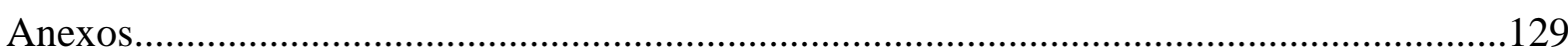




\section{"PRIMEIRO, OS ANIVERSÁRIOS": INTRODUÇÃO}

Os subtítulos desta dissertação pegam emprestado frases de músicas da cantora baiana Pitty ${ }^{1}$, para dizer de um tempo que se faz história, cultura e sujeito. Para começar, falamos de um tempo escrito na música "Temporal”, de autoria da cantora, e que define, logo de início, o tempo como tema deste trabalho. Nessa música (Pitty, 2003d), a roqueira brinca, através de um jogo de palavras e da ironia, com a relação entre tempo e temporal. O tempo que "chega simples como um temporal" quer dizer de algo que aniquila, que inscreve na pele, que se percebe nítido e vivo através do espelho, mas vem sem avisar, sorrateiro, chegando "simples" (como um temporal, que de simples não tem nada), tempestuando a história do sujeito que não se percebe mais como o mesmo.

Seguindo adiante na mesma canção, encontramos outra parte da composição que serviu de grande inspiração para este trabalho: "Quero uma fermata que possa fazer/Agora o tempo me obedecer/E só então, eu deixo/Os medos e as armas pra trás” (Pitty, 2003d). Quais seriam esses medos e essas armas que poderiam ser abandonadas se o tempo, agora, passasse a nos obedecer? Por que o tempo assusta? Como a percepção sobre tempo se faz tão presente na cultura e por que exige tanto da nossa vida, dos nossos receios e das nossas frustrações?

A Fermata é um termo técnico da teoria musical que também pode ser chamado de Suspensão. Este recurso é utilizado pelos musicistas sobre a nota para indicar uma pausa ou um prolongamento da mesma, uma parada no compasso musical, para aumentar a duração de forma indeterminada desta parte do compasso. Quando Pitty pede uma fermata para fazer o tempo obedecê-la, ela parece querer dizer de uma necessidade de prolongar o mesmo, não a vida, mas a duração dos eventos.

\footnotetext{
${ }^{1}$ Nos Anexos, lista com as letras completas de todas as músicas de Pitty utilizadas neste trabalho.
} 
Decidi me adentrar no assunto do tempo a partir de um estágio supervisionado durante o último ano de minha graduação em uma comunidade terapêutica de ex-usuários de drogas, que se estendeu de 2012 a 2013, na cidade de Catalão (GO). Era com a frase "eu sinto que estou perdendo tempo aqui" que muitos internos da comunidade se expressavam sobre a duração de seu tratamento, que se estendia por, no mínimo, 06 meses, sendo que, por ser uma comunidade aberta, poderiam se retirar a qualquer momento.

Todos admitiam a importância daquele tratamento para se livrarem do vício e do hábito de uso da droga, principalmente aqueles que ainda tinham algum vínculo com suas famílias, reconhecendo que, para cuidarem dos outros, precisavam, primeiramente, cuidar de si mesmos. Porém, a sensação quase geral era a de estarem perdendo tempo, enquanto a vida passava fora daqueles muros e eles não sabiam o que fazer. Com exceção daqueles que estavam na casa há mais tempo, e já haviam sido reinseridos no mercado de trabalho, os outros experimentavam esse mal-estar significado como um perder tempo de vida.

Esta experiência também foi marcante durante outro estágio, anterior, em 2011, realizado em uma escola da rede pública de ensino, também de Catalão, com alunos do ensino médio. Durante as orientações sobre escolha da profissão e planejamento de carreira, a maioria dos alunos apresentava o discurso que queriam acabar logo o ano letivo para poderem prestar vestibular. De outro modo, aqueles que não conseguiram esperar, relatavam já estarem matriculados em cursos técnicos. A justificativa para tal "apreensão" era a urgência de uma inserção no mercado de trabalho, para não perderem tempo e começarem a "fazer a vida", mesmo sem saberem muito bem que caminho tomar.

Estas questões da urgência em aproveitar o tempo que estava passando ficaram "martelando" na minha mente. Por que experimentamos, quase o tempo todo, a sensação de que o tempo está passando e que devemos, por obrigação, fazer algo com isso, mesmo sem saber para onde ir? Além desta questão primordial, fui inquietado pela forma como todos 
relacionavam esta "passagem incontrolável do tempo" com a exigência de estruturar a vida baseada na necessidade de se estar inserido no mundo do trabalho.

Ao pisar pela primeira vez em Brasília como um aspirante a pesquisador, e não como um turista, para tentar o processo seletivo do Mestrado em Psicologia Clínica e Cultura, me deparo, coincidentemente ou não, com um cenário bem promissor: a cidade, cheia de gente, de carros, de monumentos e concreto, diferente e estranha para um sujeito do interior, estava cheia também de poesia e, claro, de tempo, coisas que já me eram bem familiares.

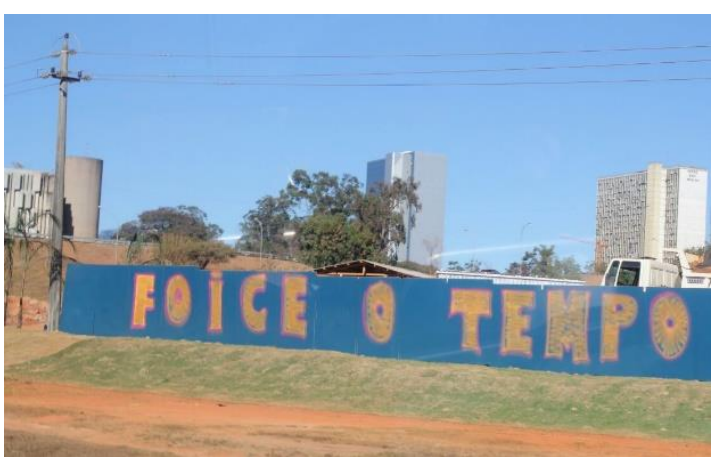

Figura 1: Foice o tempo

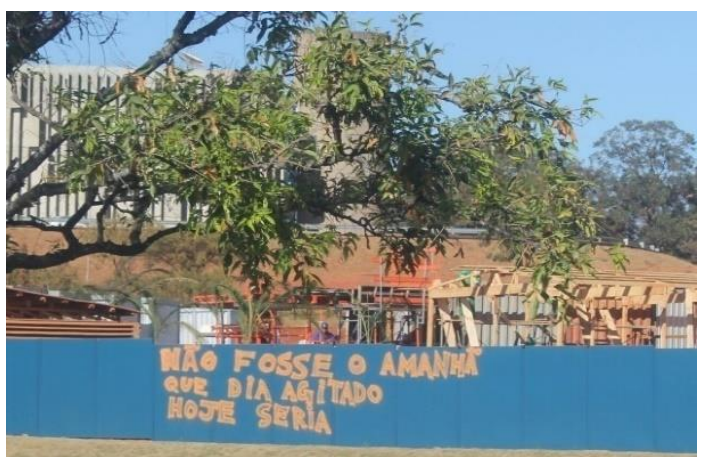

Figura 2: Não fosse o amanhã...

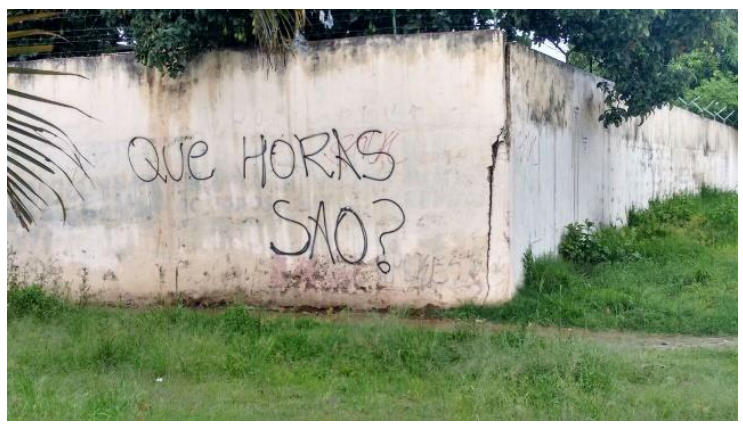

Figura 3: Que horas são?

As figuras 1 e 2 apresentam paisagens que já não existem mais: uma cerca de um pátio de obras bem aproveitado por um artista, que se localizava no início da Via L2 Norte, bem no caminho para a Universidade. Todos os dias que eu passava em frente ao lugar, minha inquietação aumentava e aquilo que, até então, era um tema de pesquisa, se configurava como a minha própria vivência, movimentado pelo poder da arte em "mexer em algo dentro da 
gente”. Já a figura 3 nos mostra um lugar longe do espaço das duas primeiras imagens, no setor P Norte de Ceilândia. Por morar nesta cidade e por conta das relações sociais que estabeleci, este muro surgiu para revirar ainda mais algo dentro de mim.

Tudo isso ocasionou uma série de inquietações: por que o trocadilho "foice", em vez de "foi-se", fazia tanto sentido? E se não fosse o amanhã, que dia agitado hoje seria? Será que se tivéssemos uma fermata, como deseja Pitty, para controlar o tempo, sua força seria menor? Conseguiríamos, então, tranquilizar o tempo(ral) que chega assustadoramente "simples"? Por que somos tão ligados às horas? Por que a vida está tão regulada ao compasso do tempo? E por que a arte é um lugar possível para se falar de tempo de maneira tão intensa e livre, ao mesmo tempo?

“Cada minuto me interessa” são palavras da música de Pitty (2003d) para dizer de uma vigilância imanente e de uma presença quase que invisível do tempo sobre nossas vidas. Estamos atrelados às horas, aos minutos, aos segundos, seus décimos, centésimos e milésimos, sejam eles importantes ou não, sejam eles fundamentais para o sujeito ou apenas como forma de se situar no momento.

O assunto do tempo desestabiliza, apresentando e forçando o reconhecimento e a convivência com as nossas angústias e as nossas defesas. Falar de tempo é, inevitavelmente, falar de sujeito, de finitude, morte, passagem e transitoriedade da vida humana, que, como sabemos por experiência própria, não são de um tanto assuntos agradáveis. A instância do tempo perpassa o sujeito, que entrelaça a própria existência em parâmetros de determinação temporal, sendo que, desta forma, deixa revelar suas angústias... seus medos, e suas defesas... suas armas.

A passagem do tempo, atrelada à vida humana, ainda é motivo de grande desconforto e, digamos, desespero. A despeito desta mensuração do tempo enquanto objeto da natureza, o ser humano tenta controlar esta força natural como se, por meio disso, conseguisse controlar o 
próprio passar do tempo, ou em outras palavras mais desconcertantes, controlar o fim do tempo, o fim de sua vida.

Por mais que o projeto moderno da ciência tenha tentado, com muito êxito aliás, explicar o fenômeno do tempo, não caminharemos acompanhados pelo viés do controle sistemático dessa instância. Adentraremos mais adiante numa espécie de zona de desconforto, por outro caminho, que não o da ousadia do saber racionalista moderno em separar o ser humano da natureza, em distanciar o que é medido e aquilo que não tem a ver com dados objetivos.

Como falar, então, de um assunto tão incômodo sem se fixar simplesmente nas explicações lógicas, matemáticas ou físicas de controle da natureza? É por isso que usamos aqui os recursos da História, da Psicanálise, das Ciências Sociais e da Arte para possibilitar uma discussão que envolva o ser humano e sua relação com a cultura, que deixem ser reveladas as nossas fraquezas e o lado "obscuro" de nossas pulsões, recusados pelo saber científico racionalista da modernidade quando a temática é o tempo e o seu desenrolar.

Freud (1927/1996e) vai dizer que a arte oferece uma substituição para as satisfações mais antigas, por meio do que sabemos ser o destino pulsional da sublimação, das quais mais sofremos e sentimos pela sua renúncia, em nome da constituição da civilização. Por tal motivo, a arte é uma forma de reconciliar o ser humano com os seus sacrifícios, com o seu lado animalesco, de uma forma aceita pela vida civilizada.

A arte é entendida, então, como um caminho encontrado pelo sujeito para exorcizar suas emoções que, segundo Mezan (1998), são um dos fatores que impulsionam o artista a criar uma obra. Porém, de acordo com o autor, apenas a emoção não é o suficiente para se dar vida a uma obra de arte, é preciso, também, que o sentimento seja transformado e expresso, ou seja, é necessário ao artista a capacidade de dar uma forma à sua experiência afetuosa. Essa experiência, entretanto, não é a experiência cotidiana, da vida diária, mas "um a mais de 
excitação que a psique tratará de ligar, isto é, vincular a representações, utilizando-o como combustível para um trabalho mental" (Mezan, 1998, p.113).

Não é a intenção aqui trabalhar detalhadamente a relação entre Psicanálise, sujeito e Arte, mas, como um caminho possível, nos aventuraremos através desta última para reconhecermos o lado vulnerável do ser humano na sua relação com o real do tempo, deixado de lado pelas explicações científicas pautadas no racionalismo moderno. Ainda em Freud (1927/1996e) é lançada a discussão de que a ciência, mesmo vangloriando-se de seus "numerosos e importantes sucessos" (p.62), é criticada por ter nos ensinado tão pouco sobre a relação do homem com a natureza, deixando um campo muito maior em aberto: o da obscuridade desta relação.

Trabalhamos com a hipótese de que existem percepções temporais que marcam as relações entre sujeito e cultura. Como falar de uma existência humana vulnerável em sua relação com o passar do tempo, reconhecendo a sua obscuridade maquiada pela ciência racionalista, senão a partir do discurso do próprio sujeito?

Pensando, então, no processo de composição artística como uma forma de (re)compor o sujeito com seus lados mais obscuros é que trazemos a música de Pitty para a discussão: ela temporaliza a cultura contemporânea de um modo em que o sujeito se faça presente nas suas palavras. O sujeito é escrito nas palavras da cantora/compositora quando escreve sobre o tempo, de uma forma que tempo e palavra, produtos da relação do sujeito com a cultura, se inscrevam, dialeticamente, na constituição desse sujeito.

Priscilla Novaes Leone, a Pitty, é uma cantora baiana de rock, contratada pela gravadora independente Deckdisc, que vem se destacando cada vez mais no cenário musical brasileiro, desde 2003, quando lançou carreira solo, após trabalhos nas bandas Inkoma e Shes (Pitty, 2014a). A despeito de números, para entendermos um pouco melhor a sua abrangência no cenário atual da música brasileira, Pitty, até o momento do desenvolvimento desta pesquisa, 
contava com quase 4,5 milhões de fãs em sua página oficial do Facebook ${ }^{2}$, aproximadamente 5,7 milhões de seguidores no Twitter $^{3}$ e quase 600 mil, no Instagram ${ }^{4}$. Além disso, somando-

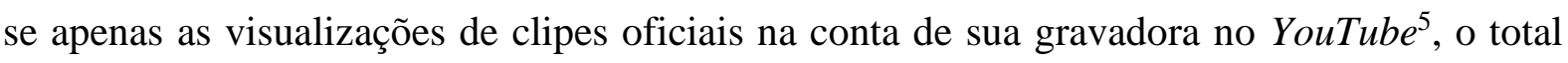
chega a cerca de 100 milhões.

Pitty ficou consagrada como a maior representante do rock brasileiro na atualidade por conta das premiações recebidas ao longo de sua carreira. A cantora já recebeu estatuetas do Prêmio Multishow da Música Brasileira, do Prêmio MTV Video Music e de vários outros prêmios de revistas, sites, rádios e programas de televisão brasileiros, como revelação, artista do ano, melhor cantora, melhor DVD, melhor disco, melhor música, melhor vocalista, melhor show etc. O reconhecimento não é apenas em território nacional: já foi indicada ao MTV Europe Music Awards, ao Grammy Latino e ao World Summit Award. O seu último disco de estúdio, Setevidas, lançado em 2014, foi mixado por Tim Palmer, que já trabalhou com grandes nomes da música internacional, como Robert Plant, Pearl Jam, David Bowie, U2, Ozzy Osbourne, Goo Goo Dolls e Tears for Fears.

Mas o que faz a música de Pitty ter tamanha abrangência e reconhecimento? De acordo com Lima (2008), a produção da cantora se insere, de modo genérico, no estilo do Rock Alternativo, que carrega traços do Punk Rock ao expor conteúdos de crítica social e insatisfação com a realidade, embora Pitty não se encaixe especificamente neste único gênero. Não nos atentando a meras classificações, sua produção diz de influências heterogêneas que acompanham a multiplicidade dos temas nas produções artísticas dos séculos XX e XXI, como o amor, a política e os discursos críticos da história, do sujeito e da cultura contemporânea.

Como relembra Lima (2008), a cantora questiona a hegemonia da produção do Rock brasileiro que tende a se afirmar no eixo Rio - São Paulo, mostrando que o gênero não se

\footnotetext{
${ }^{2}$ https://www.facebook.com/PittyOficial

${ }^{3}$ https://twitter.com/pittyleone

${ }^{4}$ https://instagram.com/pittyleone

${ }^{5}$ https://www.youtube.com/user/Deckdisc
} 
concentra em zonas específicas, mas abrange todo o território nacional. Ainda neste tom de discussão, o autor enfatiza que Pitty rompe com o estigma da Bahia do Axé e do Carnaval, gritando ideias que não são propriamente para se festejar, como alienação, comportamento social e fragilidades do ser humano. Sousa (2012) defende que a carreira solo de Pitty deu mais visibilidade à cantora e, acima de tudo, se tornou uma alternativa singular no momento de crise da produção do rock e do pop-rock brasileiro no cenário da grande indústria musical.

Vital e Queiroz (2009) afirmam que o que chama a atenção nas composições de Pitty é o seu diálogo com a estética, entendida aqui não como sinônimo de belo ou de requinte, pelo contrário, mas como jogo de palavra e uso de figuras de linguagem como a ironia e a metáfora. Sousa (2012) percebe que, a partir de relatos da própria cantora, sua escrita musical recebe influências diversas do mundo das artes, seja de outros músicos ou também da literatura. Este fator, segundo o autor, é determinante para a construção de um tom expressivo, tão marcante na composição das músicas de Pitty.

A maioria dos compositores tem uma estreita relação com a escrita, uma verdadeira entrega e devoção ao ato de escrever, e em Pitty isso não se faz diferente. A cantora adota uma maneira divergente de se trabalhar com as palavras, trazendo um tom próprio para suas composições, uma identidade marcante, através da conotação dos sentidos e dos jogos de linguagem. Esse jeito peculiar de escrever, aliado à voz única e ao ritmo próprio, fazem de Pitty uma cantora que se destaca e que cria seu caminho no mundo da música brasileira (Sousa, 2012).

A partir da atribuição de novos significados empregados às palavras que compõem a letra da música, Pitty ganha a atenção do público, utilizando suas composições para um fim expressivo, que não é fixo ou estático, e que varia de acordo com a intencionalidade das emoções que quer transmitir na construção do texto. É este jogo de cintura com as palavras que Pitty, de acordo com Sousa (2012), traz o sujeito para dentro do texto: ela faz emergir a 
"obscuridade" presente nas relações sociais do ser humano, o que a difere da maioria dos cantores evidentes no cenário musical brasileiro da atualidade.

O lema de ordem de Pitty pode ser entendido como "desconstruir e fazer pensar", ou seja, a partir de suas composições, o sujeito que ouve se desfaz da mesma forma que o sujeito conflitante que está presente no texto. Para Lima (2008), Pitty estabelece uma relação entre a composição e o seu discurso, que possibilita a crítica às formas de existência da atualidade, uma resistência ao controle e um apelo à individualidade emancipada de quaisquer formas de alienação.

Vital e Queiroz (2009) afirmam que Pitty tem a capacidade em apresentar os conflitos do sujeito da atualidade, um sujeito descentrado de si e "que se vê alvejado ${ }^{6}$ pelos ditames do capitalismo". Além disso, Sousa (2012) reconhece que fica fácil observar e refletir nas obras de Pitty o uso de palavras e expressões que demarcam a turbulência e a heterogeneidade que caracterizam o mundo atual, sem nenhuma censura e com grande capacidade de ressignificação da escrita para, assim, conseguir dizer de um mundo e de um sujeito que estão o tempo todo revendo os seus significados.

É por isso que a interlocução com a obra de Pitty se faz possível e se justifica no estudo da clínica psicológica inserida na cultura. A partir das letras de suas músicas, podemos evidenciar o tom e a questão dos processos de subjetivação em sua relação com a cultura contemporânea, deixando-se mostrar uma existência fragilizada e os meios que o sujeito encontra para vivenciá-la. Através de suas composições carregadas de sentidos e ressignificações, podemos refletir acerca da cultura contemporânea e dos fatos que permeiam a vida humana de forma crítica e contextualizada, como a relação com o tempo.

\footnotetext{
${ }^{6}$ A palavra "alvejado" nos remete a uma dupla significação: primeiro, ao sujeito alvo da política capitalista que mira e atira no ser humano e nas suas relações, reduzidas ao imperativo do lucro e, segundo, a noção de algo que precisa ser branqueado, clareado, evitado ao contato daquilo que traga qualquer possibilidade de obscuridade e inquietação ao bem-estar da vida civilizada, que, como define Freud (1927/1996e), é uma marca típica do modelo social branco europeu.
} 
O tempo constitui uma relação entre sujeito e cultura, a partir de um processo histórico que entrelaçou a vida humana como medida temporal e que, consequentemente, molda as formas como este sujeito dirige suas pulsões e seus meios de satisfação ligados ao tempo. Partese da obra de Pitty, que denuncia e expõe, através do discurso artístico, esta relação marcante em que o tempo se faz no sujeito, e vice-versa, a partir de sua realidade social.

Portanto, a problemática que move esta dissertação é a de como podemos entender o caráter temporal constituinte de uma relação entre sujeito e cultura que afirme a vulnerabilidade da vida humana? Desta forma, o objetivo desta pesquisa é entender e problematizar, dialogando com a Psicanálise, a História e as Ciências Sociais, percepções temporais do sujeito, inserido, pois, em uma cultura, usando como recurso de expressão de uma realidade social, e, portanto, temporal, as músicas de Pitty.

Ao falar de seus medos e armas, da necessidade de uma fermata para controlar o tempo, dos minutos que interessam ou não para que o temporal do tempo não seja tão destruidor, este tempo se faz no sujeito Pitty, que não o recusa, que se desloca do ideal moderno da separação entre sujeito e natureza. Ela nos convida no grito, no timbre de voz, a questionar a constituição de um sujeito no mundo a partir de uma inscrição temporal, por meio do reconhecimento de suas fraquezas. Este é o convite que também não recusaremos daqui para frente. 


\section{CAPÍTULO I}

"ESSE MUNDO JÁ FAZ MUITO TEMPO": O TEMPO

ATRAVESSANDO A HISTÓRIA

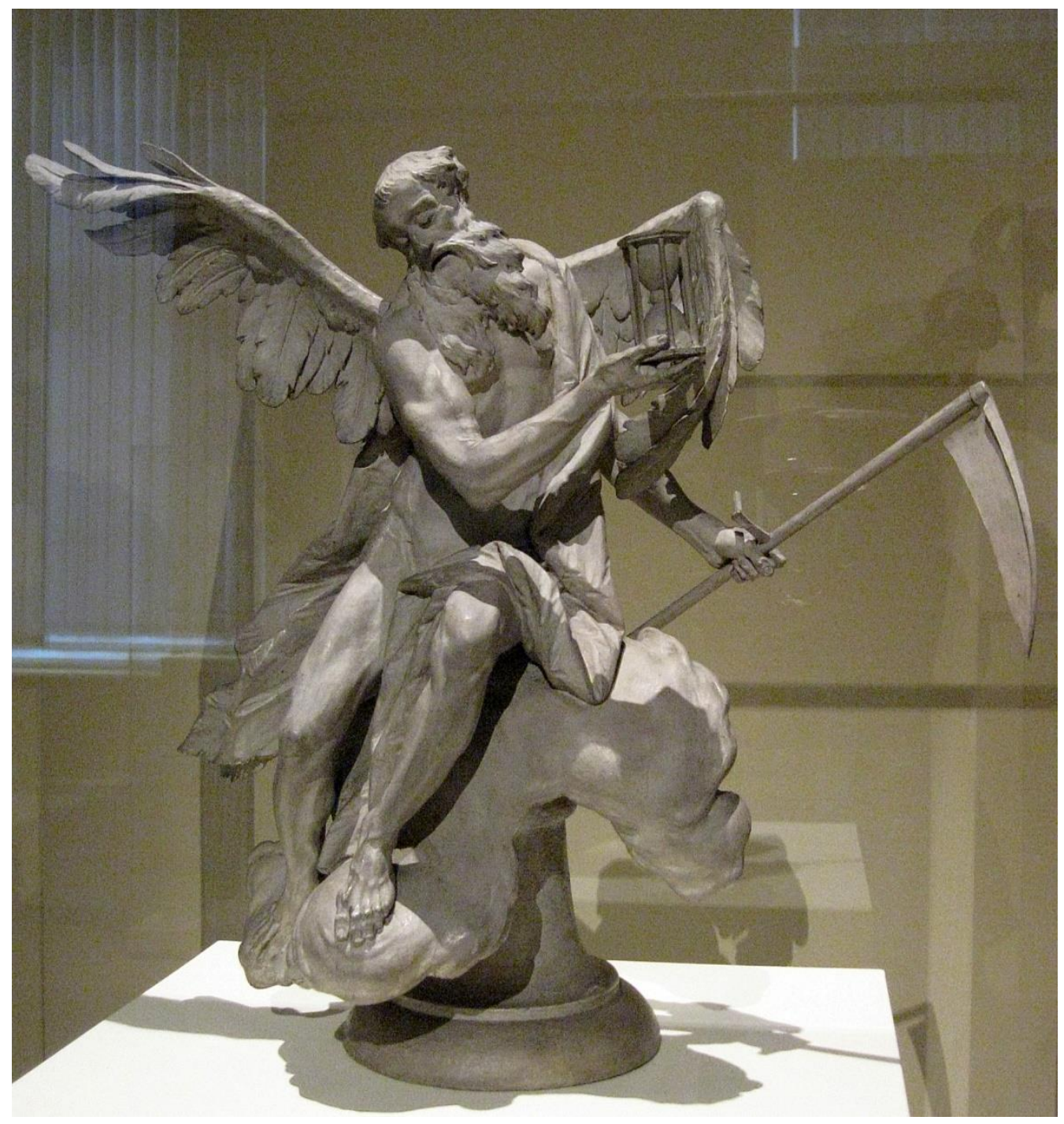

Chronos - Ignaz Günther 
“Que é, pois, o tempo?”: é com esta indagação que Santo Agostinho, em sua obra Confissões (397-398/1980), nos provoca a pensarmos sobre o tempo. "E que assunto mais familiar e mais batido nas nossas conversas do que o tempo?", continua o filósofo, ao mostrar o quanto o debate sobre o tempo está presente em nosso cotidiano. Porém, ao tentar desenvolver uma resposta, uma explicação clara a respeito do tempo, ele admite que "se ninguém me perguntar, eu sei; se o quiser explicar a quem me fizer a pergunta, já não sei”. Como, então, falar de tempo? Como defini-lo? Podemos denominá-lo como um intervalo entre dois acontecimentos no decorrer contínuo da história? Ou poderíamos dizer que é uma parte da natureza pela qual já nos inserimos simplesmente pelo fato de sermos humanos?

A discussão sobre o tempo não é um privilégio ou uma novidade advinda com a contemporaneidade, mas, como nos deixa claro Agostinho (397-398/1980), o ser humano está intrigado com a ideia de tempo e com sua importância na constituição da vida psíquica e no campo existencial desde tempos remotos. Mesmo com tamanho interesse em apreender o tempo como algo objetivo e passível de explicação lógica, não se sabe ao certo o que ele é, apenas que ele está presente na cultura e perpassa os sujeitos, sendo fundamental na estruturação de seu psiquismo e na sua relação com a realidade.

Como lembra Castro (2008), a temática do tempo atravessa grande parte das áreas do conhecimento, das mais "populares" às mais “científicas". Frases como "era uma vez”, “o tempo não para" e "a vida é o fio do tempo" mostram como o tempo está presente nas expressões. Além disso, com o mesmo efeito e magnitude, o tempo é tomado como objeto de teorização de diversos discursos da ciência. Ele é tomado como o tempo físico, o tempo da relatividade, o tempo histórico, o tempo vivido, a temporalidade, tempo e memória, o tempo psicológico, o tempo dos homens, o tempo do inconsciente e outras várias nomenclaturas para se dizer, de formas diversas, de uma mesma instância, definida por Castro (2008) como "um construto/conceito trans-temático". 
Toda a discussão acerca da temática do tempo não significa beneficiar ou eleger uma única e absoluta verdade ou discurso glorificado para tentar responder e delimitar as discussões sobre a questão resgatada por Agostinho sobre o que é, afinal, o tempo. A grande questão dos debates, teorizações, reflexões e especulações sobre este grande e vasto tema é, como define muito bem Castro (2008), reconhecer que o tempo tem um caráter imanente na cultura. Cultura e tempo estão indissoluvelmente entrelaçados.

Para Glezer (1991), a maior dificuldade para se tratar da concepção de tempo está relacionada a uma banalização conceitual, no sentido de tratá-lo apenas em sua dimensão cronológica, por periodicidade ou por divisão de eras históricas. Para ela, o tempo se transformou em um recurso técnico, classificatório, servindo apenas como ferramenta de trabalho de articulação dos fatos históricos ou de eventos cotidianos, à disposição dos estudiosos como um "elemento explicativo" para documentos e fatos. Defende a ideia de que a variável do tempo precisa ser uma questão teórica fundamental para aqueles que trabalham na construção do conhecimento histórico e subjetivo.

Para que possamos entender um pouco mais sobre a relação histórica do ser humano com o tempo se faz necessário, então, retomarmos a configuração deste em certas realidades sociais ao longo da existência da vida humana. A fim de que o tempo não seja reduzido a uma noção de eras cronológicas, estabelecimento de datas para eventos ou divisão sistemática da História, buscaremos refletir, a partir de cada contexto, as relações socioculturais que possibilitaram certos tipos de apreensão sobre o sentido do tempo.

\section{1. "Espíritos só passam por aqui”: o Tempo de Fora da Antiguidade e da Idade Média}

"Por seres tão inventivo/E pareceres contínuo/Tempo, tempo, tempo, tempo/És um dos deuses mais lindos" - Caetano Veloso 
Desde a chamada Idade Antiga do processo civilizatório podemos perceber como a concepção de tempo está intimamente relacionada ao modo como o ser humano concebe sua vida. Podemos dizer, então, que o tempo se apresenta como medida de referência da própria existência. Sêneca (2013), que foi um dos principais filósofos romanos no início da era Cristã, afirma que a maior parte dos mortais de sua época já nascia com a perspectiva de uma curta existência, de modo que todos, ignorantes ou cultos, sofreriam os efeitos dos lamentos pelo tempo limitado, sendo obrigados a encararem a morte como fato da condição existencial.

Ao mesmo tempo em que se encaminhava para a guerra e para a morte, e sofrendo por tal condição, o sujeito da antiguidade era trágico e não pessimista, ou seja, afirmava a vida a cada instante, mesmo que para isso a mesma chegasse ao fim. Este era o equilíbrio ideal entre instintos e virtudes, a morte seria o retorno à natureza (Nietzsche, 1886/1992).

Podemos perceber que, mesmo pelo fato de a vida do próprio sujeito ser transformada em escala temporal, as pessoas da antiguidade ainda traziam traços dos chamados clãs primitivos, nas palavras de (Elias, 1998). Portanto, é possível pensar que a sociedade não apresentava um desenvolvimento tal, que pudesse se desvincular, como a atual, de forma quase total da natureza e do próprio grupo social.

Para Elias (1998), estes sujeitos estavam empenhados em preparar a guerra, sendo abertos à ideia de que poderiam ser, a qualquer momento, torturados até a morte. Portanto, desde a infância, os sujeitos das sociedades mais antigas eram preparados para a eventualidade do mau resultado, a ponto de ser vergonhoso expressar qualquer tipo de sofrimento perante esta fatalidade.

Segundo Glezer (1991), com a intensificação do Cristianismo e após transformações sociais na Europa, tais como a barbarização do Ocidente e o fim do Império Romano, instaurando o início da Idade Média, a ideia antiga de tempo como aquele que nos permitia o reconhecimento da morte se alterou, quase que para um contrário. O tempo passou a ser 
percebido e significado como sinônimo de salvação, sendo menosprezado o fim da vida na Terra, e, por conseguinte, exaltada a certeza da Eternidade, o tempo da graça pela convivência com o divino, ignorando, de certa forma, a existência da finitude.

Nos escritos de Agostinho (397-398/1980), ele afirma a finitude das coisas e dos humanos, que deixavam de ser o que eram e passavam a ser o que ainda não eram. Porém, no tempo que Deus deu aos homens, o tempo da eternidade, nada desaparece ou é substituído, porque é imortal e sempre existirá enquanto criação divina. A eternidade é entendida não como um lugar em que não é tempo, mas como um tempo perpétuo e imutável, que nunca para ou acaba, diferente do tempo mundano.

Para o filósofo, os homens não conseguem compreender o tempo eterno de Deus porque existem em uma realidade em que o tempo passa, em que o tempo acaba. A morte seria, desse modo, reconfortante, pois insere o homem neste tempo infinito. Ele se lamenta pelo fato de todo futuro em algum momento se tornar pretérito, o que não acontece no tempo de Deus, que permanece sempre o mesmo e onde os anos não morrem.

O tempo é encarado como um dom, uma doação de Deus para uso dos homens, assim como teria doado os outros elementos da natureza. O tempo como dom não daria a possibilidade de controle aos homens e nem poderia ser utilizado de forma a permitir o lucro, pois, no ponto de vista teológico, esta exploração era vista como uma violação da criação de Deus (Glezer, 1991). A relação com o tempo ditava uma relação com a natureza e com o cosmos que era totalmente outra da que conhecemos:

Os corpos celestes estavam mais próximos de Deus e, por isso mesmo, não tendo máculas nem imperfeições, seus movimentos eram infalíveis e circulares. Quanto aos corpos terrestres cujos movimentos tivessem sido artificialmente perturbados pelo homem ou pelo animal, atribuía-se a eles uma tendência a retomar seu lugar "natural", o lugar de repouso que lhes fora atribuído na economia da criação divina. O recurso 
sistemático a um quadro de referência teocêntrico obrigou os homens a abordarem o problema da "natureza", e, com isso, o dos movimentos físicos, através dos conceitos elaborados de maneira a circunscrever as finalidades implantadas por Deus em todas as suas criaturas, e que estas tinham por missão realizar (Elias, 1998, pp.85-86).

É possível perceber, portanto, que, tanto na Idade Antiga quanto na Idade Média, o ser humano já se colocava no centro das referências de determinação temporal, apesar de os processos sociais ainda não se desvencilharem totalmente dos fenômenos da natureza, interpretando, desta forma, o tempo como algo externo ao sujeito, como algo controlado pela própria natureza, pelo movimento dos astros. O tempo estava fora, era uma força do cosmos que ditava o ritmo de vida humana, a qual cada grupo ou sociedade devia se submeter para sua subsistência.

Agostinho (397-398/1980), contudo, critica a noção de determinação temporal baseada nos fenômenos da natureza, propondo a seguinte questão: "Se os astros parassem e continuasse a mover-se a roda do oleiro, deixaria de haver tempo para medirmos as suas voltas?" (p.272). No lugar, ele fala de um tempo do espírito, que mede o tempo na própria alma humana, carregada de tumultos e emoções. Por isso, quanto mais a determinação temporal se confunde com a existência humana, mais o tempo parece ser um mistério, reconhecido nas palavras do filósofo quando este suplica a Deus que o faça entender os problemas deste tempo misterioso. Os primeiros relógios mecânicos, que surgem por volta do século XIII, eram fixados no alto das igrejas, que, como nos lembra Salum (2009), foi a instituição responsável por instaurar esta nova forma de relacionar o sujeito com a passagem do tempo. Segundo Kehl (2009), a passagem do tempo, que ainda estava imbricada com os ciclos da natureza, determinava o trabalho no campo e os horários dos ritos religiosos, sendo possível uma certa relação entre o tempo do trabalho comandado pelo Sol e o tempo social ditado pela Igreja. 
Apesar de tempo e sujeito estarem interligados ainda não podemos falar de uma cultura ou um período do processo civilizatório que dava lugar para a existência de um indivíduo dotado de interioridade (Carvalho, 2001; Elias, 1994; Taylor, 1989/2005). Tanto na Idade Antiga quanto na Média, o ser humano projeta para fora de si um tempo controlado pela natureza cósmica, seja por meio das estrelas e da Lua ou pela interferência divina. É só a partir da chamada Modernidade que, por meio de processos sociais, constituiu-se a possiblidade de um tempo interno, do próprio sujeito.

\section{2. "Busquei dentro de mim os meus lares": o Tempo de Dentro da Modernidade}

"O tempo humano não gira em círculos, avança em linha reta" - Milan Kundera

Com a perda da hegemonia das instituições que controlavam a determinação do tempo, como a Igreja e o saber teológico, as noções de natureza e do próprio tempo se alteraram drasticamente. O que caracterizou a mudança das relações sociais entre a Idade Média e a Moderna, segundo Elias (1998), não foi propriamente a moeda, mas a diferenciação do ritmo e da extensão do movimento, ou seja, o fortalecimento do controle individual das emoções e

também do tempo. É possível perceber, portanto, a partir da Modernidade, como a questão do tempo e do ritmo se atrelam às emoções subjetivas.

Além disso, o padrão temporal cada vez mais regente da existência humana e a sua tentativa de controle o distanciavam da dependência dos fenômenos cósmicos e proporcionavam, em alto grau, o desenvolvimento de determinações artificiais pautadas na lógica do cientificismo. Esta realidade deixa destacar como o ser humano vai tentando controlar, cada vez mais, e com mais eficácia, os fenômenos naturais, incluindo o tempo. 
Diferentemente dos grupos da Antiguidade e da Idade Média, a sociedade dos Estados da era Moderna passa a ter uma maior necessidade de medição do tempo por conta da própria exigência de demandas sociais decorrentes do processo civilizatório da urbanização, industrialização e mecanização dos fluxos. Se antes a população era predominantemente agrária, vivendo com certa lentidão em seus atos cotidianos, a partir do desenvolvimento das cidades, marcado pela produção artesanal e pelas trocas comerciais, a exigência do controle do tempo e sua relação com a vida social e individual vai se alterando (Kehl, 2009).

Se antes era experimentado um tempo externo, para além do sujeito e do grupo social, a partir da Modernidade o tempo ganha um caráter subjetivo e individual. O tempo de fora se converge em tempo de dentro. Os grupos sociais se tornam independentes em maior grau da natureza e conseguem determinar por si próprios os ritmos da vida e das determinações sociais da existência.

\subsection{1. 'Não sinhô, sim sinhô: a Disciplinarização do e ao Tempo}

Por conta das novas condições da vida econômica a medição do tempo vai se tornando cada vez mais rigorosa e precisa. Para Kehl (2009), as relações sociais não se baseiam mais nos movimentos da natureza, mas nas horas. Além disso, o tempo do comércio foi gradualmente substituindo o tempo da Igreja, transferindo os relógios, ainda sem os ponteiros dos minutos, para as prefeituras das cidades que se advinham.

Como destaca Salum (2009), no século XIV houve uma proliferação de relógios mecânicos em espaços públicos, o que resultou numa maior disciplinarização das pessoas em relação à passagem do tempo, principalmente por conta da expansão do comércio e do desenvolvimento industrial. O tempo passa a ser mensurado pela via financeira, vinculada à 
ideia de ritmo de produtividade. As ferramentas e máquinas mais avançadas possibilitam um maior grau de produção, gerando, consequentemente, mais lucro.

A determinação do tempo da natureza que constituía a base da vida social nas sociedades pré-modernas vai perdendo sua força através do que Giddens (1991) chama de "esvaziamento do tempo". Se antes as determinações temporais serviam como um padrão comunitário de organização, como o tempo da colheita e da plantação, com o desenvolvimento da Modernidade a organização social proporcionou uma determinação artificial ou virtual do tempo, pautada na vida individual. Desta forma, se antes o tempo contava com um caráter externo, fora do sujeito, agora ele apresenta um caráter cada vez mais interno: um tempo dentro de cada um.

Em numerosas sociedades da era moderna, surgiu no indivíduo, ligado ao impulso coletivo para uma diferenciação e uma integração crescentes, um fenômeno complexo de auto-regulação e de sensibilização em relação ao tempo. Nessas sociedades, o tempo exerce de fora para dentro sob a forma de relógios, calendários e outras tabelas de horários uma coerção que se presta eminentemente para suscitar o desenvolvimento de uma autodisciplina nos indivíduos. Ela exerce uma pressão relativamente discreta, comedida, uniforme e desprovida de violência, mas que nem por isso se faz menos onipresente, e à qual é impossível escapar (Elias, 1998, pp.21-22).

O tempo vai tomando gradativamente mais espaço na fruição da vida individual, destacando uma disciplinarização do tempo, cada vez mais onipresente, e ao tempo, cada vez mais regulador. É na Modernidade que pessoas, objetos e técnicas se confundem: a objetividade cresce e faz com que todos os aspectos da vida humana também se objetivem. Neste sentido, "os objetos tornam-se coisas, utensílios, instrumentos, mas ao mesmo tempo ficam impregnados de valores subjetivos, afetivos, estéticos" (Morin, 1969/2005, p.180). 
Com esta objetivação das relações humanas, os calendários e relógios ganham um caráter subjetivo e só exercem a sua função enquanto determinação do tempo porque são reguladores do ritmo social. A partir do momento em que os objetos de mensuração do tempo passam a ganhar quase que uma vida própria, eles se tornam uma fonte de poder coercitivo que o tempo exerce nos sujeitos. Cabe então pautar o seu comportamento em relação ao tempo naquele instituído pelo grupo social, que, quanto mais se torna complexo no processo civilizatório, mais controla e pressiona o sujeito a viver uma "ditadura dos relógios" (Elias, 1998).

\subsection{2. "Cada um em seu casulo, em sua direção": a Subjetividade Privatizada}

É neste cenário histórico de disciplinarização e subjetivação do tempo que se evidencia com maior força a ideia da capacidade de se construir uma história pessoal. O desejo constante de realização se torna intrínseco à vida humana, através da produção de marcas da passagem individual na história da humanidade, sendo que estas caracterizarão a plenitude ou o vazio da existência (Oliva-Augusto, 1995).

Não é à toa que na Modernidade se elevam estes ideais de liberdade, capacidade, possibilidade de construção de uma vida com sentido e realização dos desejos subjetivos. Como nos lembra Cantarelli (2013), a busca moderna por ideais individuais como estes marca o surgimento de um sujeito particular, voltado para sua produção interna, ou, como nas palavras da autora "dá tempo e espaço ao surgimento do "psicológico"” (p.13).

É na Modernidade que surge a noção de um indivíduo dotado de interioridade, como defendem Figueiredo e Santi (2006), ao proporem a noção de uma subjetividade privatizada, que se desenvolve a partir da ruptura com os tempos da Idade Média. A ideia da subjetividade privatizada é naturalmente entendida como a sensação de um íntimo em cada pessoa, 
experimentando o desejo de uma privacidade para poder decidir de forma livre o próprio destino. Cantarelli (2013) define o sujeito moderno como "aquele que está carregado, quando não soterrado, pelo seu eu em busca de autonomia, em busca de um brilho" (p.23).

Esta chamada experiência da subjetividade privatizada abre as portas para uma sensação de originalidade, quando cada pessoa, em suas ações, parece ser única no mundo e distinta das outras de seu grupo. Contudo, a percepção de sujeitos capazes de tomar decisões e regular seus próprios sentimentos e emoções só é possível em uma cultura com características específicas, como o mundo moderno. Em nenhum outro momento, senão na Idade Moderna, pôde se experimentar essa noção de um sujeito privado, um sujeito único, um sujeito original perante o seu grupo social.

Para Figueiredo e Santi (2006) a experiência da subjetividade privatizada só foi possível a partir da Modernidade graças a uma crise social em que as referências coletivas se desfizeram, obrigando ao sujeito emergente contestar as antigas formas de vida e construir novos paradigmas para a sua existência. A crise social apontada pelos autores vai obrigar os sujeitos da época a repensarem sobre si mesmos e a se lançarem em questionamentos acerca da sua própria pessoa, seus desejos e seus valores, agora sem o aval de um Imperador, de uma entidade divina ou de um Senhor. É importante ressaltar que o movimento e o desenvolvimento da experiência de uma subjetividade privatizada não aconteceram do nada, e nem foram algo linear na história. No decorrer do processo civilizatório, essa experiência foi se tornando cada vez mais parte da consciência dos sujeitos sobre sua própria existência. Desse modo, é impossível deslocar o sujeito de sua materialidade histórica.

De acordo com Cantarelli (2013), a experiência de sujeitos conscientes de sua autonomia, liberdade e da sua existência particular perante um grupo genérico não é um dado natural ou nem sempre existiu, mas só se possibilitou de fato a partir de transformações no cenário sociocultural, sobretudo com o advento da Modernidade. A abertura para novas 
descobertas e novos mundos fez da Modernidade um palco para a diversidade e a multiplicidade, até então novidades para as pessoas da época. Isso exigiu dos sujeitos a busca por novas formas de se relacionar com o outro, com aquilo e aqueles que eram diferentes. Esta abertura e a necessidade de se reconhecerem como únicos, no meio de uma variedade de formas de existências, marca no indivíduo moderno uma necessidade de proteção, ou ainda, uma necessidade em "buscar uma unidade ao se debater com a experiência da variação" (p.16).

Já a partir do Renascimento pode-se perceber a constituição de um sujeito moderno que, aos poucos, vai perdendo as bases que o ligavam aos dogmas medievais. A crise do modo de produção feudal e a abertura do ocidente para a descoberta de novos territórios lançam o sujeito moderno europeu a uma condição de desamparo. O rompimento com uma ordem superior apresenta ao indivíduo a ideia da liberdade pessoal e a abertura para o exterior, deixando-o perdido e inseguro, buscando por uma unidade de sentido para o mundo e para sua própria existência (Figueiredo e Santi, 2006).

A busca por unidade, perante ao turbilhão das novas descobertas, se configura paulatinamente com uma nova forma de se viver em sociedade. Cantarelli (2013) diz de uma sociedade que permite a busca de autonomia do indivíduo que se relaciona de forma menos estática com o grupo social.

As transformações que se operam nas formas de relacionamento do homem e no funcionamento geral da sociedade rompem radicalmente com a ordem do estático e com o padrão de busca de referencial na ordem estamentária pré-condicionada à própria existência do homem. Aliás, o homem não existia como referencial a uma individualidade, mas sempre a uma ordem social maior (Cantarelli, 2013, p.17).

O ser enquanto indivíduo é o ser da "invasão do múltiplo e exigência do único" (Cantarelli, 2013, p.17). Este ser experimenta uma nova forma de se lidar com a religião, que não desaparece por completo, porém, que trata o sujeito como o único responsável pela sua 
salvação ou condenação, atribuindo um valor maior à consciência do que para os próprios atos. O mundo deixa de ser pensado a partir de ideais sagrados e passa a ser explicado pelo que é objetivo, pelo que é construído pelo saber humano, possibilitando o fortalecimento da ciência moderna e do movimento Humanista (Figueiredo e Santi, 2006).

Com o fim do controle feudal, que apresentava o Senhor como uma figura de autoridade, e com o avanço das cidades, o ser humano se viu obrigado a escolher os próprios caminhos e arcar com as consequências de suas escolhas. Houve, então, uma valorização do "Homem" enquanto referência, o que proporcionou maior destaque ao Humanismo. Ao lado do movimento Humanista, o surgimento da imprensa também foi fator determinante para o fortalecimento da experiência da subjetividade privatizada. A leitura passou a ser realizada de forma individual e silenciosa, permitindo aos letrados o escape dos discursos coletivos e a possibilidade da construção de uma opinião pessoal (Figueiredo e Santi, 2006).

Além disso, o movimento artístico se difunde largamente, abrindo espaço para criações em que os autores pudessem falar sobre si mesmos, seus desejos, sentimentos e desamparos, a partir do Renascimento. Estes artistas valorizavam o sujeito em suas obras, ao mesmo tempo em que criticavam essa valorização, denunciando a vaidade do homem em se considerar um ser privilegiado perante a natureza (Figueiredo e Santi, 2006).

A grande valorização da subjetividade privatizada, acompanhada da intensificação de ideais críticos dos artistas, possibilitaram o fortalecimento de movimentos científicos contrários ao pessimismo encontrado nas artes: o Racionalismo e o Empirismo. Ambas as correntes científicas buscavam resgatar novas bases seguras para as ações humanas, na tentativa de evitar a dispersão ocasionada pelo Renascimento e pelo seu tom crítico. Um dos grandes nomes desta época é Descartes, que, a partir do seu método de investigação dos fenômenos, carimba a existência de um sujeito que pensa, marcada pela famosa frase "penso, logo existo" (Figueiredo e Santi, 2006). O método científico de Descartes cria um sujeito da 
objetividade que se separa da subjetividade, ou seja, através do método científico o homem consegue estabilizar seus pensamentos e fugir das incertezas do mundo e da natureza, restringindo-as ao subjetivo (Cantarelli, 2013).

Uma série de outros pensamentos filosóficos, artísticos e científicos surgem neste contexto, como afirmam Figueiredo e Santi (2006), com o objetivo de ora reforçar a supremacia do sujeito, ora questionar sua força. O Iluminismo vai, ao mesmo tempo, colocar em xeque a soberania do eu e da razão, mas também reconhecer que tudo o que existe, só existe por conta da consciência humana. O Romantismo se contrapõe aos movimentos mais influentes de até então ao dizer de um homem que não é senhor de si mesmo, que é marcado pelos ímpetos e por um lado intempestivo. O movimento do Romantismo foi determinante para a crise do eu, porém, paradoxalmente, reforçou o sentimento humano: se o homem é um ser que não conhece a si próprio, é necessário se lançar à autorreflexão e à individualidade.

Como se pode perceber, o advento moderno coloca o sujeito no centro de sua existência e das explicações acerca de si e do mundo. Em nenhum processo anterior da história da humanidade havia se experimentado tamanha produção intelectual, artística e tecnológica como na Modernidade, palco de um cenário cada vez mais múltiplo e, ao mesmo tempo, sedento de uma originalidade e unidade.

É interessante se pensar como, a partir da Modernidade, o ser humano se vê em uma realidade até então totalmente desconhecida. Novos territórios descobertos, novas ferramentas de produção, novas formas de regular a vida social e política, novos arranjos na organização e na percepção do tempo, enfim, novas formas de existência em um mundo que se revela. O ser humano nunca havia sido tão evidenciado como na vida moderna, tão lançado às múltiplas possibilidades e aos diversos meios de vivência de suas vontades.

Porém, o que parecia ser uma promissora descoberta e a promessa de uma vida até então jamais experienciada, se tornou, também, avessa ao próprio sujeito. Na medida em que as 
conquistas humanas se expandiam e o ser humano era colocado como o centro da natureza, mais a individualidade foi sendo transformada em individualismo. Quanto mais contato com o outro, mais o sujeito se voltava a si. Quanto maior experimentação, maior a necessidade de defesa. Quanto mais o ser humano se afastava de suas relações com a natureza, mais tendia na tentativa de controlá-la para se manter como o centro da existência. Atrelado a tudo isso, a intensificação do ritmo nas relações foi se tornando cada vez mais forte e determinante para estas novas configurações sociais e subjetivas.

\subsection{3. “Não deixe nada pra depois, não deixe o tempo passar": Tempo do Capital}

"O tempo é tudo, o homem é nada - quando muito é a carcaça do tempo" - Marx

Além dos movimentos artísticos e intelectuais, a transformação no contexto econômico e mercantil também marca o caráter da experiência de uma subjetividade cada vez mais privatizada, transformação possibilitada pelos ideais iluministas de igualdade e liberdade. Se antes o sistema de comercialização se dava pela troca de produção excedente entre comunidades e feudos, com o advento das cidades ele passa a ser baseado na troca de produção de mercadorias especializadas. Assim, cada um passa a produzir o que está mais capacitado, propiciando uma espécie de identificação com as habilidades pessoais. O sistema mercantil capitalista instaura a cultura do lucro e do prejuízo, sendo que, agora, cada um deve defender seus interesses particulares em detrimento dos comunitários (Figueiredo e Santi, 2006).

Para Cantarelli (2013) não se pode pensar o homem moderno como parte excluída deste contexto, pois "o capitalismo fornece boa parte dos contornos para o desenvolvimento da subjetividade humana, especialmente para o fomento da individualização" (p.26). Com esses novos arranjos do mercado e do sistema de produção, a sociedade fica cada vez mais atomizada, 
ou seja, se antes a produção era voltada para uma comunidade, agora desenvolvem-se os trabalhadores considerados livres para venderem sua força de produção a um proprietário dos bens.

Para Santos Neto (2013), a categoria do tempo de trabalho não é uma abstração fora da objetividade ou da realidade social, mas uma "temporalidade irreversível" que escreve suas marcas no ser social. Desta forma, entender que a noção de tempo de um sistema de produção regula um período histórico é reconhecer que este afeta o sujeito, uma vez que Marx, como relembra o autor, define a categoria do trabalho, e do tempo gasto a ele, como uma forma de ser, uma determinação da existência do sujeito. Assim como o tempo de trabalho faz gerar a mercadoria e movimenta a economia, "a temporalidade é uma das configurações essenciais do trabalho nas distintas sociedades de classes. O trabalho é objetivação do tempo vivo do trabalhador" (Santos Neto, 2013, p.156).

A gênese do sistema de produção capitalista está no abandono do trabalho do servo feudal e das suas relações com a terra como meio de produção. A expulsão destes trabalhadores do campo resultou na busca de uma vida melhor nas grandes cidades que se desenvolviam, fazendo-os obrigados a andar sem rumo em busca de modos de sobrevivência, em vez de encontrar amparo do Estado. Essa falta de oportunidades permitiu aos burgueses em ascensão, donos dos meios de produção, a apropriação da mão de obra destes "andarilhos" sem grandes esforços (Santos Neto, 2013).

A liberdade destes trabalhadores logo foi contestada porque mesmo que cada um pudesse escolher para quem vender a sua força de trabalho, precisava se vender de qualquer modo, para poder sobreviver ao novo sistema. Assim, a partir de sua capacidade produtiva, cada trabalhador devia superar seus concorrentes na busca de garantia de meios de sobrevivência. Neste contexto, se desenvolve o pensamento Liberal, caracterizado pela possibilidade de o sujeito ascender na vida devido à sua liberdade, à sua capacidade e à sua 
igualdade em direitos, porém, ao mesmo tempo, por ser definido como livre, se torna o único responsável pelo seu possível fracasso (Figueiredo e Santi, 2006).

Se os sujeitos podiam experimentar, cada vez mais, uma sensação de individualidade, com o crescente avanço da economia capitalista, esta individualidade se confundia, aos poucos, em individualismo: sujeitos que podiam vivenciar a ideia de uma vida privada também se viam cada um por si, abandonados a si mesmos. A alteridade, o outro, ganha um aspecto de concorrência que precisa ser superado em nome da ascensão social de cada um e, de acordo com Mészáros (2007), é justamente este o valor da vida atrelada ao capital: um valor reduzido aos significados monetários ou ao imperativo do lucro, onde "tudo que possa não ser acomodado lucrativamente no interior desses limites deve ser decretado, no melhor dos casos, como irrelevante ou inexistente, ou realmente destruído" (p.43).

Esse é o papel do outro na cultura de economia capitalista: um outro irrelevante e destruído enquanto sujeito possível de contato e relação. Segundo Barcelos (2006) encarar a alteridade é se expor, é se deixar contaminar e afetar pelo outro, porém, no contexto do capital, a afetação é um risco intolerável à vida pois ameaça os ideais da felicidade absoluta. Sendo assim, conviver com o outro no capital é viver "as formas vigentes de alteridade e de sentir, as quais anulam a presença viva do outro" (p.92).

A lógica competitiva do capital passa a determinar os sistemas produtivos e sociais, sendo que, neste contexto, o indivíduo se reduz à sua capacidade produtiva. Cantarelli (2013) diz de um "indivíduo pronto para produzir", e este estado de prontidão reflete nos modos como a sociedade capitalista, e seus sujeitos produtivos, vivenciam e se relacionam com o tempo. $\mathrm{O}$ trabalho capitalista deixa de ser um contato do homem com a natureza e consigo mesmo para reduzi-lo a um funcionário que dedica toda sua força de produção aos objetos e mercadorias que não pertencem a ele. 
Estas mesmas mercadorias assumem o papel de suprir as necessidades humanas, uma vez que, com o investimento do capital e da força de trabalho, ganham valor de uso e valor de troca, alienando não só a sua real necessidade, como também o próprio tempo de trabalho do empregado, que fica fora de seu controle. Cantarelli (2013) define a função da mercadoria como "a serviço da função do capital e, por isso, certas características humanas estão descoladas dele mesmo, como a paixão e a entrega ao desejo" (p.29). Assim, produz-se mercadorias que não têm a ver com a real necessidade da população, além de impulsionar o consumo e a acumulação desenfreados, ou como define Mészáros (2007) criar "apetites artificiais" sem nenhuma razão.

Na lógica da produção capitalista liberal, advinda com a Modernidade, é experimentada uma satisfação do prazer através do livre consumo, colocando o indivíduo emergente numa posição de advento. A sensação é a de que se tem "conquistado uma aurora no caminho da felicidade, da liberdade e da possibilidade de se constituir - na ação - por meio da mercadoria" (Cantarelli, 2013, p.30), quando na verdade o sujeito está perdido num infinito de possibilidades de consumo, que se apresenta como nova configuração social diferente daquela restrita do mundo feudal. O traço marcante da modernidade e do sujeito moderno é a contradição, pois ao mesmo tempo em que está entregue aos novos rumos, "nada mais lhe apetece como inteireza ou objetivo" (Cantarelli, 2013, p.25).

Os ideais modernos do liberalismo e da busca da felicidade e da realização do sentido de vida ganham forma através dos conceitos de indivíduo livre e de trabalhador assalariado, que caracterizaram também uma nova noção de tempo. O tempo passa a ser encarado como mensurável, disciplinado, racionalizado, de acumulação e de conquista da natureza, o que resultou na chamada colonização do futuro, sendo o homem o Senhor de seu próprio destino e do tempo (Oliva-Augusto, 1995). 
Santos Neto (2013) afirma que para a sociedade industrial moderna o tempo de trabalho e o tempo de produção são categorias fundamentais para o capital. Ele define a sociedade industrial moderna como uma sociedade que valoriza a "economia do tempo de trabalho e a economia do tempo de produção" (p.91). O tempo de produção de uma mercadoria pode ir além do tempo de trabalho despendido, ou seja, a produção pode durar mais do que o tempo gasto pelo trabalhador, se estendendo, por exemplo, por meio de máquinas que encerram o processo ou também pela estocagem do produto final. Justamente por isso o capital investido no processo de produção fica estagnado e esta estagnação é um prejuízo para o capitalista, detentor dos meios de produção.

É por este motivo que, a partir da intensificação industrial da Modernidade, os intervalos entre os turnos de trabalho são reduzidos, além de haver maior investimento em mecanismos e tecnologias científicas de controle da natureza como forma de redução artificial do tempo. Sendo assim, "com o seu aprimoramento, o capital consegue abocanhar, num mesmo espaço temporal, um quantum maior de expropriação do tempo de trabalho excedente do proletariado, efetivando vários ciclos [de produção]" (Santos Neto, 2013, p. 106). A proposta máxima do capital é reduzir cada ciclo da produção a um tempo mínimo, uma vez que quanto mais se produz, mais se vende e mais se lucra, afinal "tempo é dinheiro" e o ser humano é, quando muito, uma "carcaça do tempo".

A Modernidade, enquanto período histórico em que o homem se viu capaz de se lançar ao desconhecido, conectou vários personagens e várias novas realidades por meio do avanço das técnicas de transporte. Não só as pessoas se locomoviam com mais rapidez e facilidade, mas também as mercadorias escoavam entre os territórios de modo mais ágil e barato, com isso, o desenvolvimento dos meios de transporte não servia apenas como meio de facilidade para a vida humana, mas como forma de lucro (Santos Neto, 2013). 
Com o avanço da industrialização e das linhas de produção nas fábricas, não bastou apenas aprimorar as técnicas e procedimentos para se reduzirem os custos da produção: era preciso reduzir o quadro de funcionários, substituindo-os por máquinas. Deste modo, a “integração da subjetividade operária" no processo de produção foi elemento fundamental para o advento do capitalismo, exigindo aos trabalhadores uma aceleração das suas tarefas e a redução do seu tempo de trabalho (Santos Neto, 2013), pois quanto menos se trabalha para produzir um maior número de mercadorias, mais o capitalista lucra com o trabalho excedente da produção, ou a mais-valia. A apropriação do trabalho excedente é a grande chave para a prosperidade no capitalismo de concorrência: sem trabalho, o sujeito não sobrevive, cabendo unicamente oferecer o seu tempo e sua força ao capitalista.

Eliminar o desperdício de tempo, economizar no quadro de funcionários e ampliar o tempo de trabalho excedente por meio da aceleração do ritmo de trabalho, para encurtar o tempo total de produção, foram as grandes estratégias encontradas pelas grandes correntes do capital industrial, como o Taylorismo e o Toyotismo. Sendo assim, "o trabalhador se converte então num ser destituído de sua humanidade, considerado apenas como um ente que deve produzir mais" (Santos Neto, 2013, p.132).

A regra da intensificação da produção, através do desenvolvimento cada vez maior das indústrias e do sistema capitalista, era a de economia total. Era preciso obter apenas o que fosse necessário de matéria-prima, no momento certo e na quantidade certa, regulando o tempo de produção, o método e o destino do produto final. Desta forma, é possível padronizar toda a linha de produção, além, é claro, os movimentos e o ritmo de produção dos funcionários, que ficam excluídos do controle do processo (Santos Neto, 2013).

Cabe exigir ao trabalhador, então, uma maior preparação e multifuncionalidade: se antes o operário realizava uma tarefa específica, agora o trabalhador dinâmico faz tudo ao mesmo tempo, a fim de diminuir o tempo total de produção e aumentar a apropriação do tempo 
excedente. Para Santos Neto (2013) isto é um "ataque" ao trabalhador, uma vez que o impede de experimentar, no processo do trabalho, uma caracterização humana, uma "substância corpórea", e o reduz a uma "expressiva manifestação do trabalhador como uma coisa gelatinosa e estranha a si mesmo" (p.139).

Neste cenário em que o sujeito se vê reduzido à capacidade produtiva e alienado de sua condição humana, Mészáros (2007) problematiza ao afirmar que "um dos aspectos mais degradantes da ordem social do capital é que reduz os seres humanos à condição reificada, a fim de adequá-los aos estreitos limites da contabilidade do tempo do sistema" (p.42). Com esta afirmativa, o autor diz que o sistema capitalista se sustenta a partir de grandes perdas humanas, não só em número de vidas, mas, sobretudo, na qualidade do ser enquanto humano, em nome da velocidade e da quantidade da produção.

Desta forma, com a "decapitação do tempo", o tempo de vida humana que devia ser significativo para o sujeito perde esta condição e se torna algo reificado, regulado pela tirania imperativa do tempo do capital. Ao relembrar a clássica fala de Marx, que define o ser humano como sendo, no máximo, a carcaça do tempo, Mészáros (2007) afirma que "a existência vivida dos seres humanos individuais é subordinada a uma entidade abstrata" (p.16), a saber, a entidade do tempo do capital.

A proposta do capitalismo moderno foi a de otimizar os processos de produção de mercadorias para, em consequência, beneficiar a vida humana e torná-la mais fácil e prazerosa, compactuando com os novos ideais emergentes da Modernidade de satisfação, de busca da felicidade e da necessidade do sujeito, cada vez mais privatizado de seu grupo social, em se tornar alguém no processo histórico da humanidade, para que sua existência não se reduzisse a um simples e mero mortal. Além disso, o sujeito que estava cada vez mais desconectado da natureza em suas relações sociais se via obrigado e capacitado a retornar a esta relação, mas 
não de forma genuína, e sim a fim de controlá-la para que esta respondesse aos ideais emergentes.

A aceleração da produção, advinda do desenvolvimento das técnicas e maquinários utilizados nas indústrias, reflete na própria vida humana, que passa a tomar um ritmo acelerado e intensificado, pois, segundo a lógica moderna, quanto mais se produz, mais se satisfaz. A Modernidade, portanto, através das novas relações econômicas e de produção foi uma reviravolta na forma de como o sujeito encarava a sua relação com o tempo: um tempo que exige, que está à espreita, que precisa ser controlado, mecanizado e consumido, para que a vida humana pudesse tirar o maior proveito dessa relação.

\subsection{4. “Quem partiu a Terra ao meio?”: a Ruptura dos Tempos}

A Modernidade é, historicamente falando, o período da existência humana que marcou, de fato, a tentativa de separação entre homem e natureza, entre o que era subjetivo e objetivo, como forma de buscar explicar o mundo e seus fenômenos, através do olhar científico, enquanto produção humana. Consequentemente, são alteradas as formas de percepção dos sujeitos sobre o mundo, sobre si mesmos e suas existências, incluindo as noções de tempo, vida e morte.

A noção de indivíduo é, assim, contemporânea das alterações que se processam na noção de tempo (e na vivência dessa nova temporalidade) e do reconhecimento da finitude da vida. Essa convergência envolve, em conseqüência, profunda alteração no significado da morte. A morte deixa de ser o momento da passagem para outra existência, onde se terá o retorno - positivo ou negativo - da vida que se teve, e adquire o sentido de fim inexorável. O reconhecimento desse marco contrapõe a idéia de 
eternidade, que norteava a vivência anterior, à constatação da finitude humana (OlivaAugusto, 1995, pp.95-96).

Desta forma, a emergência de um indivíduo dotado de interioridade reformula as percepções sobre tempo, vida e morte. A perspectiva deste cenário aponta para a necessidade de vivência máxima do tempo presente, já que o mesmo é reconhecido como irrepetível, e torna urgente o aproveitamento do tempo disponível, no que diz da necessidade de preenchê-lo com acontecimentos e produções. Neste sentido, a maior preocupação com o tempo e com as medidas temporais decorrentes dos processos de urbanização, industrialização e mecanização da sociedade, bem como da expansão comercial, alteram a noção de determinação de um tempo que até então ainda estava pautado na relação entre sociedade, sujeito e natureza (Elias, 1998).

Elias (1998) aponta que, a partir das teorias físicas de Galileu a função do tempo se pauta na medida dos processos físicos, e não mais nos eventos sociais ligados à vida humana. É dessa forma que, se antes a experiência do tempo era de integração entre sujeito, sociedade e natureza, ele passa a ser denominado enquanto tempo físico, tempo de medida. A natureza torna-se, então, uma rede autônoma de acontecimentos e conhecimentos ordenados, que obedece a leis, incluindo-se o tempo.

O conceito de tempo e a sua determinação se modificam e se resumem ao estudo das sequências físicas e no desenvolvimento de uma cronologia centrada na natureza enquanto leis. Embora, segundo Elias (1998), o universo teocêntrico não tenha saído todo de cena durante a Modernidade, os físicos e a ciência renunciam a essa crença e deixam de lado a ideia de um lugar natural, divino e eterno. Logo, a natureza deixa de ter o mesmo caráter para os povos anteriores do processo civilizatório e passa a ser pensada enquanto regularidade observável que poderia ser exprimida através de equações matemáticas que logo se transformaram em leis imutáveis. A natureza que era fonte de criação humana, por meio do trabalho, se torna sinônimo de lucro e controle. 
A mudança, ou a ruptura, entre tempo social e tempo físico aconteceu paralela às novas funções dos objetos de determinação do tempo criados pelo homem, que passaram a servir para medir o tempo da natureza. Os sujeitos aprenderam a tomar distância da natureza para apreendê-la em funções e fórmulas. Nesse processo, criou-se uma polarização do pensamento: de um lado temos a concepção de tempo como um objeto e, de outro, os sujeitos conhecedores que fazem deste objeto uma propriedade natural.

Ao mesmo tempo, então, que a vida humana se faz determinação das escalas temporais, ela se exclui do processo que até então integrava-a com a natureza e os grupos sociais. Com o alto grau de complexidade e evolução do processo civilizatório marcado na Modernidade, surge este novo modelo de tempo que pauta a subjetividade a partir da disciplinarização temporal. A partir do momento em que se controla o tempo natural, cria-se uma consciência temporal global, que permite às pessoas terem uma noção de si a partir da passagem do tempo (Elias, 1998).

A hora tornou-se medida de vida, o homem passou a ter controle sobre ela: nunca perder uma hora tornou-se em virtude, tanto para a visão católica da disciplina e organização, como para o humanista, cuja virtude era a temperança. [...] A transformação foi radical: o homem do Renascimento tornou-se o senhor de seu tempo, porque passou caber a ele definir políticas, atividades econômicas e posições intelectuais (Glezer, 1991, p.263). A tecnicização e objetivação do tempo são as marcas do indivíduo privado moderno, que deseja apenas consumir a própria vida. Parece ser, então, na Modernidade, que o tempo perde o seu caráter humano e se torna fruto de uma preocupação de racionalização quase mórbida, que afasta a eventualidade, diferentemente dos povos da Antiguidade, pois ela se configura como um risco ao desconhecido (Morin, 1969/2005; 1977/2009).

Portanto, o que se vê a partir da Modernidade é que, com a intensificação das descobertas científicas e marítimas e do desenvolvimento industrial e mercantil nas cidades e 
nos novos territórios, permitindo o lucro sobre o trabalho da livre mão-de-obra humana, a ilusão do controle do tempo ficou na mão dos homens, a ilusão de que o ser humano era Senhor do tempo. Porém, concomitantemente, abriu-se espaço para um desenvolvimento contrário, do tempo enquanto Senhor destes mesmos homens, uma vez que o mundo do trabalho exigia total submissão ao tempo das máquinas, imposto ao indivíduo sob uma "lógica despótica" (Glezer, 1991). Como afirma Teixeira (2008), se o ser humano inventou o tempo, o tempo também inventou o ser humano: "apressados, atrasados, fleumáticos, serenos, agitados, impacientes, entediados. Sabemos o peso que os significantes, eterno, infinito, imortal, ressureição, renascimento, anacrônico, velhice, atraso, hora, minuto, prazo, tem nas nossas vidas” (p.106).

Segundo Glezer (1991), no início do desenvolvimento do período moderno, com suas novas necessidades, era preciso criar formas e medidas para a determinação do tempo racionalizado e mensurável, a serviço dos homens que definiam as próprias políticas e escolhas baseadas nas novas configurações temporais. Contudo, com a intensificação dessa realidade social é o tempo quem passa a ser o Senhor, a regular o ritmo de trabalho e vida destes sujeitos.

Desta forma, observa-se uma nova relação com a natureza e bem-estar humano, a medida em que os sujeitos têm a capacidade tecnológica e cognitiva de marcar sua relação com aquilo que, até então, se encontrava externo a eles:

O domínio cognitivo das ligações através de distâncias maiores no tempo e no espaço foi um componente indispensável do processo mediante o qual o saber humano reduziu seu conteúdo imaginário e aumentou sua congruência com o real. Ele permitiu que os homens ampliassem constantemente seu controle sobre a natureza externa, assim reduzindo o nível de perigo a que estavam expostos, ainda que, vez por outra, tenha contribuído para aumentar o perigo que os homens representam uns para os outros (Elias, 1998, p.142). 
Se antes os sujeitos estavam mais dependentes da natureza e estritamente ligados aos seus grupos sociais, agora, através de transformações radicais na exploração do mundo e nos modos de produção de materiais humanos, surge um indivíduo privado que está mais interessado em satisfazer seus desejos e anseios. A natureza passa a ser, como dissemos, ilusoriamente controlada com maior facilidade. O ser humano que busca se distanciar da natureza para atingir seus novos ideais também é o mesmo que não sabe muito bem como agir longe dela. Por isso busca, através de formas diversificadas como a ciência, a racionalização e a subjetivação dos elementos abstratos do tempo, controlar esta natureza a fim de que ela passe a obedecê-lo.

\section{3. "O futuro é o presente, e o presente já passou": Novos Tempos, Tempos de quê?}

“Correr atrás das coisas e capturá-las em pleno voo, ainda frescas e cheirosas - isso é in. Adiar, escolher o que já está lá, é out" - Zygmunt Bauman

Nas sociedades mais atuais, cada vez mais complexas, o tempo vai ganhando uma nova concepção, a partir de um sujeito social que tem se constituído com uma percepção de tempo diferenciada de outras épocas. O tempo, hoje, vem sendo percebido como fragmentado, instantâneo, efêmero e imediato, que se impõe ao próprio sujeito, ou ainda, um tempo que aniquila o tempo. Esta é a chamada sociedade do tempo real que se desloca da noção de passado, condensa o presente no imediatismo e resume o futuro numa cadeia infinita de possibilidades (Glezer, 1991).

Sociedade essa que, como afirma Mészáros (2007), limita a vida a um emaranhado de intermináveis decisões instantâneas, a partir de uma ordem vigente de percepção do tempo, em nome das relações de interesse estabelecidas socialmente. Nas palavras de Gallano (2008), a 
sociedade atual, uma sociedade em rede, restringe o tempo em processos acelerados, tornando a sequência temporal imprevisível e aleatória, sendo que, com quanto mais pressa se corre, menos tempo se tem.

Esse modo de organização do tempo traz uma percepção de que tudo o que demanda duração é perda de tempo, por conta da ordem temporal vigente que Mészáros (2007) chama de eterno presente: um presente constante que limita o passado a uma "projeção pregressa" ou ainda como uma simples justificativa do que está estabelecido momentaneamente. Ainda neste caminho, o futuro se torna nada mais do que uma extensão do aqui e agora, sempre repetitivo, ou um "currículo de possibilidades futuras, e o anseio por dias melhores" (Barcelos, 2009, p.58), como se pudéssemos afirmar que "o futuro já começou" e tem começado a cada instante vivido. Assim, o agora não tem sentido enquanto constituinte da vida, mas tudo se resume à importância do agora.

Mészáros (2007) define o eterno presente enquanto uma carência de sentido, uma vida de "apuro e inelutabilidade", na qual cada momento vivido é encarado com apreensão por ser decisivo para a constituição da vida. Portanto, vivemos num tempo de urgências e emergências, quando nada pode ser deixado passar, num lugar que o passado já não interessa e o futuro é uma rede incerta de decisões que tomamos e construímos a cada milésimo do hoje. Contudo, não caiamos na inocência de pensar que o presente está carregado de valor e significado, pois, se cada instante se faz importante para a constituição da vida, é porque nenhum instante é tão significativo o suficiente. Por isso o presente "está fadado a permanecer ilusório porque é esvaziado [...] de toda significação pretendida, não apenas no que se refere à sua matéria, mas também à sua forma" (Mészáros, 2007, p.51).

Nesta realidade que altera as formas subjetivas de percepção do tempo, o presente se faz cada vez mais importante, porém cada vez menos significativo pois já embute em si mesmo a noção do futuro. É por isso que nada pode durar, que a duração é encarada enquanto perda 
de tempo, pois o eterno presente em que cada instante se faz determinante, nada mais é do que, como define Barcelos (2006; 2009), um desespero em relação ao futuro, um instante preocupado com o que vem depois, um tempo de pressa que aguarda resultados finais.

Segundo a autora, é muito difícil, com a nossa percepção atual do tempo, se abrir para "gordos intervalos sutis" e significativos, ou, nas palavras de Mezan (1998), para os tempos de muda, em que o sujeito possa experimentar novas formas de vida e novas afetações. O presente se torna, então, uma "forma estática, um regime de temporalidade instantâneo, sem duração e sem espessura" (Barcelos, 2006, p.66).

Giddens (1991) provoca ao dizer que a organização social pautada no tempo coincide com a expansão da Modernidade e continua mesmo nos tempos atuais. Devido ao chamado “esvaziamento do tempo", a determinação temporal e, consequentemente, a regulação da vida, se desloca da presença do tempo medido pelos relógios para um tempo cada vez mais “fantasmagórico". O tempo fantasmagórico é um tempo que não está encenando, um tempo invisível que marca as relações humanas.

É neste tempo fantasmagórico que Kehl (2009) reconhece o sujeito que vive nas sociedades contemporâneas. Uma sociedade de automatismos, que altera as percepções de um sujeito que incorpora todas as possibilidades, numa tentativa de buscar alguma referência ou base, já que sua condição é incerta. É preciso lidar o tempo todo com o esperado, mas também com aquilo que não se pode controlar, com aquilo que foge ao modelo automático em que se vive.

Para Kehl (2009), o sujeito das sociedades mais complexas vive e age como se estivesse fora de sua própria existência, pois, por conta desta relação com um tempo fantasmagórico, tem a noção de que o próprio mundo está para "além do possível”, para além da realidade. Parece contraditório, pois, como se evidenciou em momentos anteriores, o "tempo de fora" era experimentado na Antiguidade e na Idade Média, como uma forma de perceber o tempo como 
pertencente à natureza ou a Deus, externos ao ser humano. Além disso, o "tempo de dentro" diz da Modernidade, em que o processo de individualização da subjetividade se expandiu, colocando o ser humano no centro do universo e de sua relação com a natureza.

Contudo, na contemporaneidade do esvaziamento do tempo, do tempo fantasmagórico, não podemos dizer de um tempo de dentro ou de fora. O tempo está dentro e fora. É nesta contradição que Kehl (2009) diz do sujeito fora de sua realidade, um sujeito que já não sabe de onde as coisas vêm, de onde se constroem suas relações com os outros e com o mundo.

Dunker (2008) define bem esse sujeito que sente ser tempo, uma vez que ele demanda aproveitamento, porém ser, também, fora do tempo. É este o sujeito que sente que há algo “novo acontecendo em outro lugar", numa "época marcada pela sensação de que há um grande evento em curso, em algum lugar ocorre uma grande festa, da qual estamos sempre em atraso ou exclusão" (p.24). O sujeito se torna, então, um tempo que não sabe do lugar de onde vem, um tempo que não dá espaço, um tempo que se atrelou ao próprio sujeito estranho e alheio a si.

O tempo é a vida humana e, justamente por este caráter intrínseco, vive-se correndo contra ele mesmo, como se estivesse algo acontecendo fora de mim e que precisasse ser encontrado. As exigências temporais marcam os ritmos acelerados e, ao mesmo tempo, a incapacidade de sistematizar o cotidiano sem o controle das mesmas. Por conta da maior dependência das medidas temporais, a sensação cada vez mais vivenciada é a de falta de tempo, que, se configurando enquanto a própria existência, se torna também a falta da vida (Kehl, 2009). O sujeito que corre em busca de um tempo que está em algum lugar e contra o tempo que está passando, é o sujeito que busca a própria vida, mas vive contra ela, pois cada segundo deste tempo buscado é um segundo de tempo perdido. Cada ato realizado na vida para tentar correr atrás do tempo é um ato de perda de tempo: isso é o paradoxo do tempo. 
O sujeito contemporâneo se vê numa corda bamba, numa linha tênue entre aquilo que pode e o que não pode sentir. Em outras palavras, há de se encarar aquilo que é conhecido, o que pode ser esperado e o imprevisível, o eventual, o que foge ao controle. A ideia que se tem é que o tempo pode, cada vez mais, ser controlado. Contudo, há também o fato verídico de que controlar o tempo, em termos científicos, não diz do controle do fim do tempo, do fim da vida humana, é por isso que:

Em nossos dias, vive-se a simultaneidade de duas percepções com conteúdos opostos.

De um lado, está a visão, que ainda permanece, da possibilidade de um progresso ininterrupto; de outro, a constatação de que esse imenso e irrefutável desenvolvimento nem sempre corresponde à melhoria da qualidade de vida das pessoas (Oliva-Augusto, 1995, pp.96-97).

Oliva-Augusto (1995) afirma que em função desta simultaneidade de percepções - em que se encara ora a possibilidade de um progresso, ora que este não basta para o bem-estar humano - a morte também vai ganhando outra configuração. Os sujeitos vivem de forma a tentar negar a existência da finitude, mesmo sabendo que vão morrer, logo, todos os atos para disfarçar a presença do fim também se constituem da falta de sentido, uma vez que este se faz inevitável.

Mesmo reconhecendo o esforço e a conquista da ciência em trabalhar sobre as consequências do transcorrer do tempo, como o envelhecimento e, claro, a morte, ainda não podemos dizer do controle sobre o fim da vida. Se, nas sociedades ocidentais contemporâneas, algo que dura é perda de tempo e o ser humano nega seu fim, ele, mesmo sem querer, vive uma sensação de que a própria vida, que dura, é uma perda de tempo. Neste sentido, Lombardi (2008) afirma que o tema da finitude do tempo está instalado, porém, o sujeito "fala de si de um modo impessoal, que se opõe igualmente à surpresa e à determinação" (p.19), ou seja, não se fala nem que o fim está determinado e nem que ele chega sem se esperar. 
Como diz Barcelos (2006), em sociedades como as nossas, vivendo em uma época que não se fala de dor e se afirma o tempo todo a necessidade do bem-estar, naturalizamos os discursos da saúde e do prazer e evitamos aqueles opostos, "em nome de uma vida saudável e politicamente correta, que se preocupa com a beleza e, também, com a boa forma e a longevidade. Em épocas de promessa de bem-estar contínuo, somos complacentes com várias coisas que nos acontecem" (p.104), inclusive com o tema da morte. Assim, segundo Lombardi (2008), a morte existe para o sujeito, porém, não por enquanto.

Com o modo específico de se tratar o tempo e a morte na atualidade, pode-se pensar em uma valorização que ora prima pelo futuro como possibilidade, ora afirma o peso do imediatismo presente como forma de corresponder às falsas ilusões que se tem do mesmo futuro. Portanto, viver deixa de ser um fator constituinte do sujeito para se tornar um processo desprovido de sentido da realidade, pois nem o agora e nem o depois são, de fato, aproveitados. Como consequência disso, podemos perceber, além do aumento do consumo e do lazer excessivos, a fragmentação da vida em conjuntos de atos irrisórios e sem sentido, que conduzem à solidão, à exclusão da subjetividade em nome da racionalização da existência (Oliva-Augusto, 1995).

O sujeito contemporâneo está tão imerso no tempo urgente, do presente que se faz um gatilho para o futuro, que parece ser impossível conceber outras formas de viver no mundo que não sejam congruentes com a velocidade e a pressa, ou ainda, de viver nesta percepção precisa, que leva em conta os décimos de segundo (Kehl, 2009). A autora retoma uma frase de Valéry em que este diz que "não existe mais o tempo em que o tempo não contava", para se referir ao tempo contemporâneo como o tempo da impaciência, da rapidez da realização e das variações bruscas das percepções.

De acordo com Kehl (2009) uma das ordens da vida contemporânea é aproveitar o tempo, que se abre a uma cadeia de possibilidades para o desfrute da vida, sendo assim: 
O indivíduo, sob o capitalismo liberal, dispõe de uma enorme variedade de escolhas quanto ao desfrute de seu tempo livre, não mais regulado pelos ritos e pelas proibições da vida religiosa nem limitado pelas horas de luz do dia ou pelo maior ou menor rigor das estações. [...] Não me refiro ao ócio, essa forma de passar o tempo tão desmoralizada em nossos dias, mas às atividades de lazer, marcadas pela compulsão incansável de produzir resultados, comprovações, efeitos de diversão, que tornam a experiência do tempo de lazer tão cansativa e vazia quanto a do tempo da produção. Nada causa tanto escândalo, em nosso tempo, quanto o tempo vazio. É preciso “aproveitar" o tempo, fazer render a vida, sem preguiça e sem descanso (Kehl, 2009, pp.124-125).

Portanto, mesmo encontrando múltiplas possibilidades do que Kehl (2009) chama de desfrute da vida privada, a partir da Modernidade, e cada vez mais nos dias atuais, o sujeito se vê num lugar do impossível, pois carrega em si o paradoxo do tempo. Controlar o tempo e a natureza pareciam a única saída para a soberania de um indivíduo que estava em ascensão, porém, agora, é o tempo quem exige do sujeito, que não pode permanecer vazio, pois é preciso dar sentido.

Para Barcelos (2009), se a subjetividade moderna se recusava a se desprender da referência científica que lhe garantia certa estabilidade perante o novo, na contemporaneidade as formas de vida são arrancadas deste lugar de segurança. Hoje, é exigido que se mude sempre, que se adapte às novas demandas do mercado, produzidas em larga escala e de modo ávido, o que "dificulta ainda mais a criação de espaços de problematização das políticas do tempo, que, geralmente, nos deixam com medo de sermos engolidos por ele" (p.63).

O tempo já não pode mais ser ou estar vazio, é preciso fazer algo, sempre, para que não caiamos no perigo e nas armadilhas de não estar fazendo a vida, ou, como define Mészáros (2007), na angústia de nossa vida de tudo ou nada. A produção e o lazer, o tempo de trabalho 
e o tempo livre se confundem nos dias atuais, pois é preciso dar sentido a cada minuto, é preciso fazer com que o tempo, que já não pode mais ser controlado, seja vivido intensamente a cada instante. Se somos arrancados de uma posição fixa em nome do mercado altamente flexível, precisamos encontrar um modo de não sermos consumidos.

O tempo se tornou, então, a própria subjetividade, um tempo-subjetividade que dita o ritmo, não apenas no que cabe aos dias, horas e minutos, ou o ritmo do cotidiano, mas, também, um tempo-subjetividade que produz formas de vida, de existência. Vivemos um temposubjetividade que nos demanda conexão, precisamos estar dentro dos processos sociais, precisamos saber de todas as novidades, precisamos viver o novo pelo novo, o ato pelo ato, mesmo que vazios. Já que o tempo e o sujeito não podem ficar vazios, é preciso ser pleno, de atividades, de aproveitamento, porém, de acontecimentos frescos e não de coisas ultrapassadas, sem dar tempo para que o sujeito se preencha de sentido. 


\section{CAPÍtUlo II}

“MUDARAM OS HORÁRIOS, HÁBITOS, LUGARES": A

CONSTITUIÇÃO TEMPORAL NA RELAÇÃO SUJEITO E CULTURA

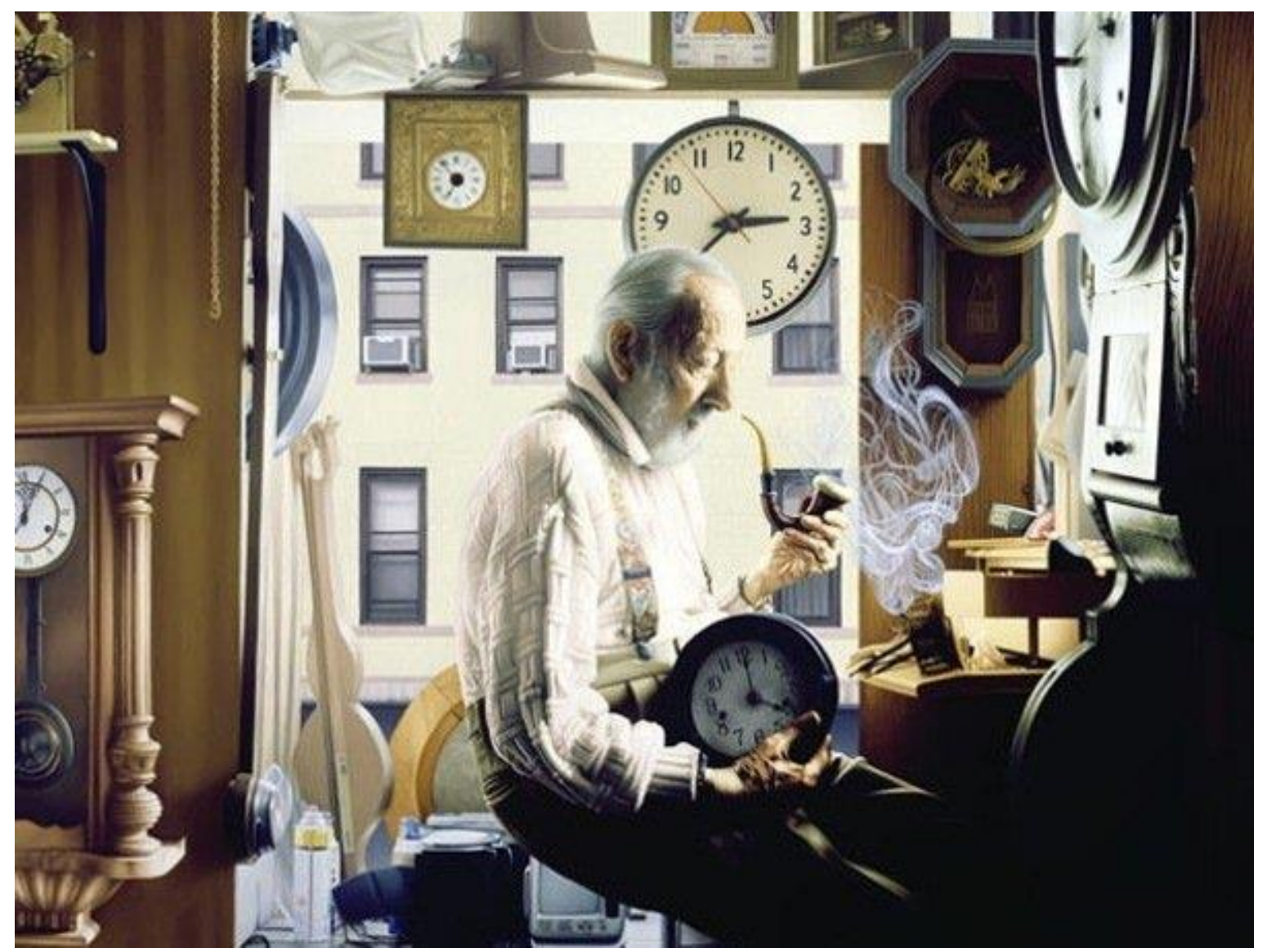

Time - Max Ferguson 
Como ficou explicitado no capítulo anterior, a possibilidade de um resgate, que permitiu um melhor entendimento de percepções históricas do tempo, se dá pelo tempo estar inteiramente ligado à realidade social e cultural. O tempo natural, que desenrola, é reconfigurado a partir das diferentes percepções que se tem dele no decorrer da história humana, estando diretamente relacionado às transformações nos contextos sociais e culturais que ditam o rumo do processo civilizatório, a partir da materialidade histórica das relações.

Santos Neto (2013) defende que a categoria do tempo não deve ser entendida como uma abstração. $\mathrm{O}$ autor compreende, ainda, que esta categoria deve ser tratada como uma temporalidade que marca o ser, enquanto sujeito histórico e social, na sua relação com a cultura. Desta forma, é possível pensar em formas de existência nesta relação, que imbricam dialeticamente tempo, sujeito e cultura, sem que um discurso, individual ou social, prevaleça ou exclua um ao outro.

De acordo com Elias (1998) esta exclusão, este reducionismo sobre o tempo, remete a um problema conceitual que expressa um dualismo entre "natureza" e "sociedade", ou seja, denuncia a existência de uma cisão entre tempo físico e tempo social. Enquanto o tempo dito físico expressaria as variáveis imutáveis de medições e equações, entendido como representação das leis da natureza, o tempo social seria uma instância reguladora da vida e da experiência humana. Por conta deste impasse ideológico e conceitual, arraigou-se no pensamento ocidental a divisão de tempos naturais, sociais, objetivos, subjetivos, físicos ou humanos, como se cada um dissesse de um tempo diferente, de tempos que se excluem perante os outros.

Umas destas visões a que Elias se propõe descontruir é a da Física Clássica. Newton (1687/1990) criou uma noção do tempo ao afirmar que o tempo é absoluto e verdadeiro em si mesmo e, por conta desta natureza, ele flui de modo uniforme e sem relação com as coisas exteriores. Neste sentido, Elias (1998) deixa claro que o tempo está longe de ser um dado 
puramente objetivo e que, mesmo fluindo, as suas percepções estão intimamente relacionadas aos processos históricos e sociais.

A noção de tempo nas ciências físicas remete à possibilidade de mensuração deste fenômeno. A quantificação do tempo pode ser chamada de duração e a localização espacial de algum evento nesta duração é denominada como momento. É possível, ainda, em termos numéricos, dar à duração e ao momento a sua exatidão, que marcam os segundos, minutos, horas e assim por diante (Aguilera, 2008).

A noção clássica da Física cria a ideia de que a realidade temporal pode ser explicada apenas através da quantificação dos fenômenos e da possibilidade de encontrar uma variável que diz da duração dos eventos, excluindo o que esteja fora da mensuração, como o passado, que já deixou de existir, e o futuro, que ainda não existe em noções de momento. Desta forma, define-se o tempo apenas como o intervalo entre duas situações, passíveis de medida e de existência objetiva, sendo, de acordo com Araújo (2004), independente das coisas e da consciência, um dado independente dos sujeitos.

Segundo Aguilera (2008), por outro lado, na obra de Einstein há uma transformação do conceito clássico do tempo newtoniano. A Teoria da Relatividade inaugura um conceito de tempo relacionado à velocidade, ou seja, o tempo não é absoluto, pois dois referenciais podem senti-lo de diferentes formas. O tempo pode causar uma sensação diferente nas pessoas, porém, ainda exige uma medida repetitiva, que independe do observador.

De acordo com Elias (1998), apesar do avanço de Einstein na compreensão do fenômeno físico do tempo, ao trazer a diferença das percepções e o caráter relativo (e não mais absoluto) do tempo, a noção de percepção ainda se reduz ao mensurável, ao que se pode determinar pelo relógio, à duração exata do evento:

Por último, foi a Einstein que coube evidenciar que o tempo é uma forma de relação, e não, como acreditava Newton, um fluxo objetivo, um elemento da criação nas mesmas 
condições que os rios e as montanhas visíveis, e tão independente quanto eles da atividade determinativa dos homens, a despeito de seu caráter invisível. Mas o próprio Einstein não foi muito longe e não conseguiu escapar por completo à coerção do fetichismo verbal. A sua maneira, ele restituiu substância ao mito do tempo reificado, através, por exemplo, de fórmulas que sugeriam que o tempo, em certas circunstâncias, podia contrair-se ou dilatar-se. Ele só evocou os problemas do tempo dentro dos limites do quadro de referência dos físicos (Elias, 1998, p.38).

De forma que não se causa surpresa, a técnica que captura o intervalo de tempo, mesmo que móvel, ainda é mais importante que a percepção dos observadores. Ao se tratar da primazia da técnica, Morin (1969/2005) afirma que a mesma transforma as relações entre os homens e o mundo, por objetivar, racionalizar e despersonalizar todas estas relações. Segundo ele, existe uma coisificação que reduz todos os fenômenos a algarismos, que causa uma alienação provinda da quantificação.

Sendo assim, falar do desenvolvimento da civilização tecnicista e da primazia do dado objetivo sobre a subjetividade, significa dizer que a técnica fragmenta diversos setores da vida humana, como o tempo (Morin, 1969/2005). Tratar a técnica como absoluta, criando a noção de que o tempo é simplesmente um dado empírico, faz com que sua redução à mensuração seja uma resposta isolada e autoexplicativa, com valor em si mesma, desconsiderando o sujeito como parte da ciência e a lógica na qual estão inseridos.

Outra noção criticada por Elias (1998) é a de que o tempo é uma estrutura a priori do espírito, noção essa proposta por Santo Agostinho e Kant e altamente desenvolvida na fenomenologia de Heidegger. Para o autor, estes filósofos não questionam o porquê da força que esta experiência do tempo tem sobre os sujeitos e não refletem sobre os processos históricos, enquanto transformação dos estilos de vida, que levaram na formação destas noções de tempo. 
Agostinho (397-398/1980) entende o tempo enquanto o "Verbo de Deus que permanece sobre mim eternamente", ou seja, sustenta uma noção de que o tempo é uma criação divina e que toma conta do sujeito por sua condição imperfeita. Enquanto que, para Heidegger (1927/2005), o tempo é uma estrutura universal da consciência humana, definido através do termo Dasein, que pode ser entendido como a síntese dos acontecimentos em relação ao tempo no ser.

Elias (1998) afirma que os pensadores sobre o tempo - seja na Física Clássica ou na Filosofia Existencial - caem em uma armadilha conceitual que eles mesmos criam. É certo que todos eles trazem avanços nos estudos sobre o tempo enquanto natural ou existencial, porém, deve-se estar atento para o contexto histórico sobre qual cada um produziu seus conhecimentos.

Nessa linha de raciocínio, Mészáros (2007) vai afirmar que, ao falar de tempo, devemos estar atentos ao fato de que o tempo humano se pauta no decorrer da produção material da história da humanidade e não em explicações metafísicas ou cosmológicas. Além disso, “as determinações objetivamente conflitantes do tempo são inseparáveis da natureza das forças sociais que competem no palco histórico, opondo-se umas às outras em razão de seus interesses e antagonismos socialmente construídos" (p.321).

A limitação dos autores criticados por Elias, obviamente, não é em si a sua teoria, que se fazem válidas, a partir do que se propõem, mas o modo como elas tomam o tempo como algo inscrito no ser humano de forma inerente e imutável, que faz parte de sua consciência ou existência de forma natural. Existência esta isolada de qualquer aprendizagem ou inserção na cultura, e, ainda, de qualquer discussão crítica e contextualizada acerca da realidade social.

Segundo Gagnebin (2005), falar e pensar sobre o tempo reduzido em termos, imagens, números e conceitos espaciais torna-se impossível entender sua condição, portanto, não se pode dizer do tempo apenas em termos cosmológicos ou em medida de movimento, mas, também, com a ideia de uma interioridade psíquica ou de percepção. Para trabalharmos a questão 
epistemológica do tempo é fundamental, como defende Castro (2008), reconhecer que, por ser um conceito trans-temático que perpassa "qualquer lugar em que o sujeito se encontre” (p.62), ele não pertence a uma ou outra área do conhecimento, sendo, antes de tudo, onipresente por ser subjetivo. Desta forma, o tempo é entendido, então, enquanto estrutura da linguagem e do sujeito e, mesmo que seja passível de representação numérica, não deixa de ser uma representação encontrada pelo sujeito.

É a partir desta lógica crítica que Elias (1998) vai dizer de um tempo que não existe em si: é com esta constatação que baseia suas reflexões sobre a questão do tempo e sua relação com a natureza, a sociedade, o processo civilizatório e a constituição do que ele chama de "personalidade" humana. Ao trazer tal afirmativa, o autor nos convida a encarar de forma crítica e desnaturalizada o entendimento do mistério do tempo para o ser humano.

Sendo assim, chamamos a atenção para que o tema do tempo seja entendido em sua amplitude, porém, deixamos claro o caminho que tomaremos adiante: não se trata de uma exclusão do tempo físico, do tempo lógico, do tempo natural etc., mas sim, de um reconhecimento que a existência de todos estes tempos cindidos dizem de uma relação entre sujeito e cultura, que possibilita a criação de várias formas e visões para dizer sobre o tempo. Ainda além, esta relação com o tempo, tão discutida, diz de um tempo-subjetividade, de formas de entendimento de como o tempo regula a vida humana e social. Onde há tempo, não importa a ideia adotada, há sujeito e onde o sujeito está, o tempo conta.

\section{1. "Mas pare e perceba como o seu dia-a-dia mudou": do Tempo como Símbolo Social}

Elias (1998) afirma que o tempo é um símbolo social, porque não existe apenas naturalmente e independentemente do ser humano, mas também não é exclusivamente uma invenção humana. O símbolo do tempo não independe do pensamento e da linguagem, assim 
como pensar que o tempo só existe por conta do sujeito é afirmar que ele surge do nada, como algo natural na razão.

Pensando-se assim, num tempo enquanto símbolo social, podemos integrar seus aspectos naturais, culturais e humanos, ou seja, como um dado da evolução social que se torna parte da individualidade dos sujeitos, sujeitos estes que estão inseridos em um universo físico. Superando essa divisão de setores e reconhecendo a interdependência entre natureza, sociedade e sujeito, superamos a cisão provinda do desenvolvimento do ideal racional da ciência moderna. O que Elias (1998) afirma é que o tempo só se tornou um símbolo de coerção e de tamanho interesse na existência humana num período tardio, e é justamente por isso que ele é de natureza social, exercido sobre a vida do sujeito, e que também diz de dados naturais, como o envelhecimento.

Enquanto não tivermos presente no espírito essa relação indissolúvel entre os planos físico e social do universo - enquanto não aprendermos a ver o surgimento e o desenvolvimento das sociedades humanas como um processo que se desenrola no interior do vasto universo alheio ao homem —, não conseguiremos apreender um dos aspectos essenciais do problema do tempo: o "tempo", no contexto da física e, portanto, também no da tradição dominante na filosofia, é um conceito que representa um nível altíssimo de síntese, ao passo que, na prática das sociedades humanas, reduz-se a um mecanismo de regulação cuja força coercitiva percebemos quando chegamos atrasados a um encontro importante (Elias, 1998, p.39).

A determinação do tempo enquanto símbolo social se pauta na relação entre o modo de funcionamento desta determinação e a representação que os sujeitos têm de sua vida social e da sua própria existência (Elias, 1998). Sendo assim, é na relação entre o desenrolar do tempo natural, o desenvolvimento do processo civilizatório, a maneira como as pessoas determinam 
o tempo segundo as necessidades sociais e a integração da própria vida em todo este processo que podemos dizer do tempo.

Afirmar que o tempo natural se relaciona com a vida em sociedade e com a vida individual é dizer da relação entre tempo, processo civilizatório e constituição psíquica. Ou ainda, nas palavras de Kehl (2009), deve-se reconhecer que a significação da forma de se experimentar o tempo está sujeita às transformações culturais: segundo ela, a noção de "dia" não era experimentada da mesma forma em sociedades em que as relações com o tempo não determinavam o ritmo social, diferentemente das atuais, em que "cada minuto exige uma decisão e promete alguma forma de satisfação” (p.122).

Elias (1998) diz de uma exigência do tempo da qual é difícil escapar, revelando uma noção de tempo tão interiorizada pelas pessoas que chega a ser estranho imaginar que outros grupos sociais viveram e se relacionaram de maneiras diversas com esta instância. De acordo com Giddens (1991), é necessário traçar contrastes entre as noções de tempo das sociedades pré-modernas e modernas para compreender as transformações que este conceito sofreu durante a história da humanidade. Feito isso, de forma inicial, podemos tentar entender, a partir de agora, como as ideias presentes do tempo puderam ser, de fato, interiorizadas na vida social e psíquica.

Ao propor uma análise histórica e sociológica da evolução da cronologia, Elias (1998) deixa claro que antes dos grupos humanos a noção de tempo não se sustentava. Mesmo depois do surgimento de comunidades humanas, o tempo era mais pautado na natureza ou pela necessidade comum do próprio grupo social. É só com o desenvolvimento dos processos civilizatórios, enquanto processos históricos e sociais, que o tempo ganha um caráter onipresente para o indivíduo.

O tempo, para Elias (1998), se tornou uma representação simbólica de uma rede de relações individuais, sociais e físicas, devido à intensa transformação da humanidade e do seu 
processo de civilização. Nas sociedades complexas, o tempo faz parte da rede de símbolos que os sujeitos aprendem em vida social e são obrigados a se familiarizarem, relacionando posições temporais na sucessão dos eventos físicos, no desenvolvimento da sociedade e no decorrer da vida individual.

Nas sociedades mais complexas, o conjunto desses símbolos do calendário torna-se indispensável à regulamentação das relações entre os homens, quer se trate da estipulação dos dias de férias ou da duração de um contrato. O conhecimento do calendário, tal como o do tempo dos relógios, é uma evidência tal que já não suscita interrogações. Já não nos perguntamos como puderam os homens coexistir, em épocas anteriores, sem a ajuda de um calendário ou de relógios, agora que esses meios se tornaram quase indispensáveis a qualquer forma de vida social. [...] Sentimos a pressão do tempo cotidiano dos relógios e percebemos — cada vez mais intensamente à medida que envelhecemos — a fuga dos anos nos calendários. Tudo isso tornou-se uma segunda natureza e é aceito como se fizesse parte do destino de todos os homens (Elias, 1998, pp.10-11).

Os símbolos artificiais presentes nos relógios e nos calendários são entendidos na sociedade atual como sendo o próprio tempo. Elias (1998) afirma que essa noção do tempo enquanto símbolo só é possível num mundo com pessoas que aprendem associar a essas figuras certas cargas de sentido existencial, como meio de orientação, integrando tanto os processos biológicos, como o envelhecimento, quanto sociais e individuais.

Elias (1998) afirma que nos grupos pré-humanos a vida seguia sempre o mesmo curso, do nascimento à morte, porém a ordenação desse processo, pautada no decorrer dos anos, só foi possível com a ascensão do humano, que, lentamente, criou o conceito temporal de ano. Assim, como vimos anteriormente, em cada sociedade, ou em cada momento do processo civilizatório, o tempo ganha novas interfaces e dimensões e não se configura simplesmente 
como uma criação humana. Não é à toa que Kehl (2009) coloca o tempo como uma construção cultural, ao dizer que "toda ordem social é marcada, à sua maneira, pelo controle do tempo" (p.111).

O que cabe a ser questionado neste momento é como e porque chegamos a essa determinação e autodisciplina do tempo, além de analisar a constante transformação nas estruturas sociais e sua relação com a percepção apurada que temos do tempo nos dias mais atuais. Como o processo civilizatório transformou a noção de tempo e favoreceu o surgimento de uma constituição psíquica pautada na questão temporal?

\section{2. "Não me leve agora": o Sentido Existencial como Determinação Temporal}

"O tempo é a coisa mais importante; é um simples pseudônimo da vida" - Gramsci

As formas de determinar o tempo se alteraram no decorrer da história humana, sendo que o próprio conceito de tempo e as percepções subjetivas sobre ele também se transformaram até chegar no que entendemos hoje. Torna-se impossível compreender esse estado atual se não nos lançarmos à ideia de que, a partir do momento em que tempo e sujeito se entrelaçam em uma carga de sentido da própria existência, o tempo passa a ser parte da própria subjetividade.

O fato de a regulação social do tempo estar tão marcada em nível individual contribui para consolidar essa consciência do tempo e tratá-la como quase que inalterável, como se a percepção que temos hoje do tempo fosse intrínseca à natureza humana ou como uma própria natureza humana. Para Elias (1998) e Kehl (2009) existe uma forte relação entre esse processo de individualização do tempo e o processo civilizatório, ou seja, entre o tempo e a inserção do sujeito na cultura. 
O fato de essa sensibilidade ao tempo, onipresente e sempre vígil, ser o sinal de um processo de civilização é algo que só se evidencia, sem dúvida, ao compararmos esse habitus social com o de homens que vivem em sociedades de estrutura mais simples, menos exigentes quanto à exatidão temporal. Durante milênios, houve grupos humanos que puderam viver sem relógios e sem calendários (Elias, 1998, p.23).

Por isso, Elias (1998) retoma uma construção das noções de tempo para mostrar como o entendimento que temos do tempo hoje foi possível graças ao decorrer do processo civilizatório. Segundo ele, nas primeiras aldeias e grupos humanos, a interdependência entre os sujeitos era quase mínima, sendo assim, a consciência humana estava muito mais pautada nos ciclos naturais repetitivos do que no passar dos anos, que não existiam enquanto conceito simbólico.

Por isso, o tempo não dominava tanto a existência desses povos, sendo importante apenas como fornecimento de materiais para a sua existência. Nas palavras do autor, "em certas épocas, os homens utilizavam a noção de 'sono' quando hoje falaríamos de 'noite', a de 'lua' quando falaríamos de 'mês', e a de 'ceifa' ou 'colheita' quando falaríamos de 'ano"' (Elias, 1998, p.35).

Nesses estágios da civilização o tempo apresenta um caráter passivo, sendo que sua determinação mal chega a ser sentida ou experimentada pelos sujeitos. A relação com o tempo se pautava mais na vida coletiva do que na determinação de desejos individuais, ou seja, as necessidades coletivas imediatas tinham mais nitidez do que qualquer outra forma de experimentação do tempo, como a necessidade da realização da vida pessoal.

Não tem nada a ver com o fato de aproveitar a vida ao máximo no presente, ideia que surge mais tarde no desenvolvimento social, mas numa incapacidade de projetar suas necessidades para outro tempo. A síntese de conceitos sobre o tempo quase não existia e talvez 
por isso o seu horizonte, ou a sua perspectiva de vida pautada na relação com o tempo, se configurava como inexistente, em relação a dos dias atuais.

Essa situação começa a se modificar quando as tribos vão se tornando cada vez mais sedentárias, passando a produzir o seu próprio alimento. Se antes a relação com o tempo era passiva, no sentido de obedecer aos ritmos da natureza para o funcionamento da vida coletiva e individual, como, por exemplo, dormir com o pôr do sol, ou pescar apenas quando o rio estivesse em condições, agora a experiência com este tempo se torna ativa. Esta relação passa a ter um caráter de controle social e pessoal sobre o decorrer dos eventos naturais. Um exemplo é a agricultura, que exige dos sujeitos uma disciplina para que os alimentos possam ser cultivados e colhidos (Elias, 1998).

Com o desenvolvimento da agricultura as primeiras comunidades se relacionavam de forma ativa com o movimento do Universo, a fim de satisfazer as suas necessidades sociais e individuais. Para Elias (1998), os sujeitos da época começaram a estudar as conexões dos corpos celestes e sua significação para a vida humana. Nesse ponto da história, natureza e sociedade ainda não eram entendidos como campos distintos e desvinculados.

Quanto mais essa relação entre sujeito e natureza avançava, mais era necessário tentar criar escalas naturais de medição do tempo, como a partir do uso de quadrantes solares e da sistematização do movimento da Lua, a sucessão das estações e o ritmo das marés, como formas socialmente reconhecidas para avaliar o intervalo entre estas transformações (Elias, 1998). Por consequência, essas sociedades foram se tornando cada vez mais complexas e as redes de interação entre os sujeitos se tornaram mais avançadas e específicas.

Por exemplo, era preciso, como deixa claro Elias (1998), saber o tempo não mais apenas da colheita, mas também da troca das figuras de poder como os caciques ou sábios. Com isso, a humanidade começou a ganhar certo grau de autonomia sobre as escalas naturais de medição do tempo e desenvolveram mecanismos artificiais, como as ampulhetas e os calendários. É 
importante deixar claro que o vínculo com a natureza não se desfez por completo, como se pode ver nos calendários do Sol ou da Lua dos povos pré-colombianos, entretanto, o desenvolvimento do calendário supõe um alto grau de complexidade e de transformação da vida social daquele povo.

Alguns processos caracterizados por um desenrolar contínuo, como a maré montante e a maré descendente, ou o nascer e o pôr do Sol ou da Lua, podem desempenhar esse papel. Quando os homens consideram que esses processos naturais são imprecisos demais para servir às finalidades que eles lhes destinam, resta-lhes a opção de construir padrões de medida mais exatos e mais confiáveis. Os relógios não são outra coisa senão "contínuos evolutivos", processos físicos dotados de um desenrolar contínuo, elaborados pelo homem e padronizados em algumas sociedades para servir de quadro de referência e escala de medida a outros processos de caráter social ou físico (Elias, 1998, p.39).

Para Elias (1998) o ser humano teve de percorrer um caminho difícil para conseguir se orientar melhor, substituindo, aos poucos e lentamente, os movimentos dos corpos celestes por referenciais artificiais. É a partir desta transição processual, e não abrupta, que a sincronização entre as ampulhetas, os relógios, calendários e o funcionamento social e comportamento humano passa a fazer parte da consciência do tempo como um componente da própria natureza humana.

Segundo o autor, o tempo está ligado ao processo civilizatório na medida em que os grupos humanos são capazes de experimentar os seus acontecimentos na dimensão do tempo. Isso ocorre porque, com o desenvolvimento das sociedades, a vida social coloca problemas cada vez mais complexos que requerem uma determinação temporal. Além disso, a própria organização social, com a evolução de seus conhecimentos, permite uma nova série evolutiva, ou seja, um novo quadro de referência e padrão de medida socialmente aceitos. 
Com esta série de transformações que permitiram uma relação cada vez mais ativa com os eventos naturais para se criar padrões de medida socialmente aceitos e, ainda, a partir da utilização de meios artificiais para se dizer dessas relações, as pessoas vão se tornando cada vez mais dependentes destes mecanismos, tornando o passar do tempo como algo de sua natureza. Se o tempo natural antes ditava todo o ritmo da vida social e humana, agora o grupo humano age sobre este tempo natural, na medida em que o regula, em que cria escalas para capturar esta repetição dos movimentos cósmicos, desenvolvendo os instrumentos necessários para tal, que servem de referência não apenas destes movimentos naturais, mas também sociais e pessoais.

Se antes as pessoas pescavam quando o rio permitisse, agora elas sabem quando o rio estará propício para a pesca. Se antes plantavam quando começasse a época da chuva, agora sabem quando ela vem e quando ela vai embora. Aos poucos, vão se transformando as relações com a natureza e demarcando intervalos, eventos, fluxos contínuos, ou seja, determinando o tempo. Portanto, é neste sentido que Elias (1998) insiste que o tempo não existe por si só, ele precisou ser determinado. O que não significa dizer que se trata apenas de uma criação humana, já que o fluxo da vida e o desenrolar do tempo seguem sem impedimentos, sem controle dos sujeitos. Entretanto, este desenrolar carrega modos perceptivos específicos aos quais os sujeitos atribuem significados distintos nos diferentes contextos e momentos do processo civilizatório.

O fato de a humanidade começar a determinar o tempo que antes corria passivamente, sem sua percepção, implica, segundo Elias (1998), um conjunto de relações: entre os sujeitos humanos, que estabelecem estas relações, e outros processos que desempenham um padrão de referência dentro de determinado grupo social, como saber em que época plantar, ou ainda medir a duração de discursos dos sábios, como os gregos faziam através das ampulhetas. O que Elias quer dizer com isso é justamente de uma constituição temporal que se dá na relação do sujeito com sua realidade cultural. 
$\mathrm{Na}$ verdade, a experiência do tempo como um fluxo uniforme e contínuo só se tornou possível através do desenvolvimento social da medição do tempo, pelo estabelecimento progressivo de uma grade relativamente bem integrada de reguladores temporais, como os relógios de movimento contínuo, a sucessão contínua dos calendários anuais e as eras que encadeiam os séculos (Elias, 1998, p.36).

À medida que as sociedades se tornam mais complexas, que os processos de agrupamento começam a aumentar e as civilizações vão se tornando mais especializadas, a regulamentação temporal precisa ser mais exata e a criação de símbolos artificiais se adapta à vida, integrando a sociedade, seus símbolos e os sujeitos. É devido a este desenrolar que as pessoas começam a determinar suas atividades dentro de uma perspectiva temporal antes mesmo da proposição do problema: não é preciso mais esperar a condição favorável à pesca, podemos criar as nossas próprias condições.

A confecção de calendários representa uma determinação temporal socialmente construída e padronizada, que serve de referência para os sujeitos realizarem as suas atividades. Giddens (1991) chega a defender a ideia de que o calendário, desde sua origem nas sociedades agrárias, foi uma característica tão específica do desenvolvimento social e tão significativa para a humanidade como a invenção da escrita.

Quando os sacerdotes, ou mais tarde os governos, desenvolvem os calendários, isso permite a projeção de tempos passados e futuros, que até então não tinham como ser ditos. Segundo Elias (1998), os calendários que medem o tempo a longo prazo indicam às pessoas a sua própria idade, remete à sua própria história. Nestas sociedades surgidas mais tardiamente no processo civilizatório, o passado, o presente e o futuro se distinguem. Se antes a determinação temporal dependia diretamente do problema social, agora "a necessidade e a capacidade de imaginar de antemão — e portanto, de levar em conta — um futuro relativamente 
distante exerce uma influência cada vez maior no conjunto das atividades realizadas aqui e agora" (Elias, 1998, p.115).

Antes os sujeitos só experimentavam demandas momentâneas por não saber projetá-las a outros tempos, como dormir ou caçar para a sua sobrevivência. Agora, nos estágios mais avançados do processo civilizatório e com o desenvolvimento de determinações temporais mais complexas e artificiais, eles podem lançar suas expectativas a tempos futuros e saber quando será melhor realizar ou não cada atividade ou satisfazer cada desejo. Desta forma, o avanço no processo civilizatório vai, cada vez mais, interligando sujeito e tempo.

Esse tipo de controle e coerção das marcas sociais rege o comportamento individual. Portanto, a partir do momento no processo civilizatório em que o tempo passa a ser determinado de forma ativa e artificial pelos sujeitos, principalmente com a construção dos calendários e o reconhecimento de uma vida baseada em possibilidades, a determinação temporal e a vida individual se entrelaçam.

[...] quando sua própria vida lhe serve de continuum padronizado para a determinação temporal de outros processos, a relação funcional é tripolar: o indivíduo está presente, primeiro, como a pessoa que estabelece e mantém relações (que "determina o tempo"); segundo, como aquela continuidade evolutiva entre nascimento e morte que serve de conjunto padrão; e por fim, há um grande número de outros processos cuja duração ele mede em referência à duração de sua própria vida, isto é, a ele mesmo como continuidade evolutiva. Para evitar qualquer mal-entendido, acrescento que essa possibilidade de fazer o desenrolar da própria vida desempenhar esse papel de continuum padronizado só existe em sociedades altamente industrializadas (Elias, 1998, p.40).

Elias afirma que a possibilidade de a vida humana se inserir como uma referência temporal só foi possível em sociedades altamente industrializadas, a partir da Modernidade. 
Porém, podemos perceber a relação entre vida humana e determinação temporal já desde a Antiguidade, nas sociedades clássicas do Ocidente. O que precisa se esclarecer é que quanto mais os grupos e as civilizações se tornaram urbanizadas, mecanizadas e industrializadas, mais elas se distanciaram da natureza e se utilizaram de meios artificiais de determinação do tempo, como a própria vida. Com o avanço da complexidade social e pela expansão do comércio fícou cada vez maior a necessidade de relacionar e interligar as atividades humanas com uma rede de determinações temporais.

É neste sentido que Mészáros (2007) afirma que, com a inserção da história humana na ordem natural do mundo, a dimensão do tempo ganha um novo caráter: a questão do significado da vida se coloca como pauta, "mesmo que deva percorrer um desenvolvimento histórico muito longo antes que os objetivos emancipatórios nela implícitos possam tornar-se realidade e ser conscientemente perseguidos pelas pessoas como projetos humanos historicamente articulados" (p.34). Ou seja, o tempo de vida se torna significativo, estabelecendo uma relação estreita com o desenvolvimento da produção humana, que aos poucos retira os sujeitos da condição de mera sobrevivência e institui a capacidade de realizar escolhas genuínas numa escala temporal.

A partir dos processos históricos e sociais que permitiram o surgimento de um indivíduo dotado de interioridade e fizeram com que o tempo se tornasse a própria existência humana, podemos dizer de uma constituição psíquica pautada no tempo. Quanto mais os sujeitos se tornam disciplinados por meios artificiais de medição temporal e quanto mais o processo civilizatório demanda esta disciplina, o tempo passa a ser entendido como constituinte da própria vida e se confunde com os ideais subjetivos modernos de autonomia e satisfação dos desejos individuais. É importante sempre frisar que esta constituição temporal do sujeito só se dá através de sua relação com a cultura e com seu mundo externo, como prosseguiremos. 


\section{3. "Foi sem hora pra voltar": um Sujeito Temporal à Espera da Satisfação}

“A vontade não pode querer para trás: não pode aniquilar o tempo e o desejo do tempo é a sua mais solitária aflição". - Nietzsche

Ao dizer da intensificação do entrelaçamento entre determinação temporal e existência humana, Elias (1998) defende que ao longo do processo de civilização a estrutura da personalidade dos sujeitos se modifica por conta das novas percepções temporais que regulam a vida social e individual. Segundo o autor, nenhum grupo social, mesmo os mais antigos, existe sem cargas de pulsão, que habitam uma pessoa e são controladas e reguladas de acordo como cada sociedade ensina. Neste sentido, buscamos através da teoria psicanalítica entender um pouco mais sobre como se dá a relação entre a pulsionalidade e suas formas temporais nos sujeitos a partir do avanço do processo civilizatório.

O tema do tempo é vasto e até motivo de contradições em Psicanálise: podemos encontrar discussões a respeito das diversas temporalidades nas psicopatologias, do tempo de análise, do tempo de elaboração do conteúdo do inconsciente, entre outros. Buscaremos nos atentar, mais especificamente, a como se dá a realidade temporal da pulsionalidade para entender que "o inconsciente é obra do tempo, ou mesmo o inconsciente é o tempo" (Askofaré, 2008, p.26), que coloca o tempo na sua posição daquilo que é Real para o sujeito, ou como define Aparício (2008), uma “universalidade da categoria a qual ninguém escapa” (p.27).

Kehl (2009), Freud, ao longo de sua obra, e outros autores da Psicanálise desenvolvem com mais profundidade a relação entre tempo e constituição psíquica. Se nos atentarmos à obra de Freud podemos notar que, de certa forma, existem discussões em dois campos distintos para se dizer do aspecto temporal do psiquismo. Por um lado, há uma noção mais estrutural (Freud, 1915/1996b; 1920/1996c; 1925/1996d; 1933[1932]/1996g) sobre onde se dá a formação das ligações que o psiquismo constrói com o tempo da realidade externa. Por outro, uma mais 
qualitativa ou funcional (Freud, 1911/1996a; 1933[1932]/1996g) sobre como as percepções e representações temporais se apresentam no interior do aparelho mental.

No que diz respeito ao aspecto estrutural, parece nunca ter havido uma teoria final para explicar o lugar (ou lugares) onde acontecem os processos temporais, sendo que o próprio autor diz que "muitíssimas vezes, tive a impressão de que temos feito muito pouco uso teórico desse fato, estabelecido além de qualquer dúvida, da inalterabilidade do reprimido com o passar do tempo. [...] E, infelizmente, eu próprio não fiz qualquer progresso nessa parte" (Freud, 1933[1932]/1996g, pp.78-79). Já no aspecto qualitativo o autor chega a um pensamento mais claro sobre a relação entre tempo e funcionamento psíquico ao propor que o aprendizado do tempo se dá na inevitável espera da satisfação das pulsões infantis, quando o bebê percebe que o princípio de prazer está sujeito ao de realidade, ou seja, seus desejos passam pelo crivo da espera e da demora (Freud, 1911/1996a).

Um dos primeiros esboços consistentes da relação entre psiquismo e mundo externo, ou melhor dizendo, entre psiquismo e fisiologia, para se falar do caráter estrutural do tempo, se dá em Freud (1915/1996b). No seu texto "O Inconsciente", defende que as excitações fisiológicas sensoriais alteram as terminações das células nervosas e deixam marcas estruturais no córtex cerebral, passíveis, inclusive, de localização. Justamente por isso, estas excitações não possuem um caráter de todo estático, pelo contrário, elas se configuram como um processo, pois marcam não só uma apresentação sensorial, como deixam uma modificação no córtex, definida como "a possibilidade de recordar".

A possibilidade de recordar é, então, o correlato fisiológico que se dá no psiquismo marcado pelos traços deixados pelo processo de modificação. Contudo, Freud duvida que há algo psíquico que corresponda a este processo de modificação celular ao dizer que "nossa consciência nada revela que justifique, do ponto de vista psíquico, o nome de uma 'imagem mnêmica latente" (Freud, 1915/1996b, p.215). Segundo ele, quando o mesmo estado do 
córtex, ou o mesmo lugar das primeiras marcas de modificação são novamente provocadas, o aspecto psíquico tende a ressurgir como imagem mnêmica.

O que Freud quer dizer com isso é que os processos temporais (ainda chamados de “possibilidade de recordar”) são puramente processos fisiológicos, que se localizam em algum lugar do aparelho nervoso e que, quando ativados pela excitação, se reapresentam enquanto memória. O ponto em que parece ter havido um equívoco, e que será remediado mais tarde, é pelo fato de desconsiderar os processos mentais como processos psíquicos do ato de recordar, resumindo-os à necessidade de uma excitação fisiológica.

Apenas com as discussões presentes em “Além do Princípio de Prazer” é que Freud (1920/1996c) vai reconhecer a consciência e o inconsciente enquanto processos psíquicos relevantes no que se diz respeito às discussões sobre o tempo, que independem da excitação fisiológica. Segundo ele:

[Os processos inconscientes] não são ordenados temporalmente, que o tempo de modo algum os altera e que a idéia de tempo não lhes pode ser aplicada. Trata-se de características negativas que só podem ser claramente entendidas se se fizer uma comparação com os processos mentais conscientes. Por outro lado, nossa idéia abstrata de tempo parece ser integralmente derivada do método de funcionamento do sistema Pcpt.-Cs. (Freud, 1920/1996c, p.39).

É neste ponto de desenvolvimento de sua obra que Freud relaciona o externo e o interno, o fisiológico e o psíquico enquanto interdependentes nas discussões sobre o caráter temporal do psiquismo. O sistema Pcpt.-Cs. (perceptivo-consciência) produz percepções conscientes de fontes de excitação que chegam pelo mundo externo e também dos sentimentos de prazer e desprazer que surgem do aparelho psíquico. Segundo Freud, este sistema tem uma "posição no espaço" definida como uma "[...] linha fronteiriça entre o exterior e o interior; tem de achar-se 
voltado para o mundo externo e tem de envolver os outros sistemas psíquicos" (Freud, 1920/1996c, p.35).

O próprio Freud (1920/1996c) reconhece que o assunto do tempo e sua relação com os traços deixados nos sistemas conscientes ou inconscientes mereciam um trabalho mais exaustivo e, por ora, se contenta em dizer que tais ideias lançadas são puramente sugestões. Contudo, em “A Negativa” (1925/1996d), o autor dá um novo passo nas discussões sobre o funcionamento dos sistemas e nas suas relações com excitações e traços de lembrança. Segundo ele, não necessariamente o inconsciente ou a consciência guardam e ativam traços mnêmicos, mas são, sobretudo, acionados pelo ego, através de uma "apalpação motora". Para ele, a percepção não é um processo passivo, sendo assim, o ego envia catexias ao sistema perceptual para classificar os estímulos e se recolher novamente.

Somente na Conferência XXXI (1933[1932]/1996g) é que Freud retoma a relação do psiquismo com o tempo de forma mais direta. Ele volta a reconhecer que no Id, entendido como conteúdo puramente inconsciente, não há nada que reconheça a passagem do tempo e que seus conteúdos não sofrem nenhuma alteração desta passagem, uma vez que "impulsos plenos de desejos, que jamais passaram além do id, e também impressões, que foram mergulhadas no id pelas repressões, são virtualmente imortais; depois de se passarem décadas, comportam-se como se tivessem ocorrido há pouco" (p.78). Desta forma, ele afirma que

A relação com o tempo, tão difícil de descrever, também é introduzida no ego pelo sistema perceptual; dificilmente pode-se duvidar de que o modo de atuação desse sistema é o que dá origem à ideia de tempo. O que, contudo, muito particularmente distingue o ego do id é uma tendência à síntese de seu conteúdo, à combinação e à unificação nos seus processos mentais, o que está totalmente ausente no id (Freud, 1933[1932]/1996g, pp.80-81). 
Ao afirmar que o próprio ego é quem regula as relações de tempo no psiquismo (ausentes no id), seja no papel de mediador entre os princípios de prazer e realidade, seja na função de trabalhar conscientemente as sensações e percepções provindas do externo a partir do sistema perceptual, Freud (1933[1932]/1996g) se convence de que existe uma relação entre tempo e psiquismo pautada na relação entre ego e percepção do mundo externo, ou seja, entre sujeito e cultura. Ao inserir também o ego nas discussões da relação temporal do psiquismo, Freud reconhece que a noção de tempo compõe o sujeito. Não unicamente o sistema Pcpt.-Cs. ou o inconsciente guardam informações a respeito do tempo, mas o ego é quem media estas informações no psiquismo, quem dá síntese ao seu conteúdo.

Para Kehl (2009), nesse sentido, o tempo ganha uma face invisível e onipresente, afirmando que a qualidade que define o psiquismo é temporal através da mediação entre ego/realidade/prazer e desprazer. Neste sentido, Teixeira (2008) defende que “o tempo não está a serviço da subjetividade, posto que o tempo é subjetividade, o tempo produz gozo enquanto atributo da subjetividade" (p.106). Assim, podemos entender o tempo como sendo a própria subjetividade, um tempo que produz formas de satisfação, de manejo das pulsões e dos conteúdos inconscientes.

Em Freud (1911/1996a) podemos encontrar uma explicação ao dizer que o ego sintetiza e organiza os processos mentais. Encarando o tempo como a própria subjetividade, que organiza as formas de satisfação, o tempo-subjetivação (Teixeira, 2008) ou, ainda, a espera da satisfação relembrada por Kehl (2009), são trabalhados em Freud (1911/1996a) quando este desenvolve noções dos princípios de prazer e realidade que atuam sobre o mecanismo de ação do ego.

O princípio de prazer é denominado em Freud (1911/1996a) como um processo inconsciente primário, um processo que se esforça simplesmente por alcançar o prazer, afastando a atividade psíquica de qualquer circunstância que lhe cause desprazer, atuando por 
meio do recalque. Porém, com a ausência da satisfação prazerosa esperada, ou com a impossibilidade de atingir um prazer, o psiquismo abandona essa tentativa de satisfação e decide agir de forma mais real, em relação às ofertas da realidade. É neste ponto que se introduz um novo princípio, secundário, que apresenta na mente não mais aquilo que é considerado agradável, mas o que é real, mesmo que desprazeroso: o princípio da realidade.

A representação do objeto de satisfação que cause prazer é denominada por Freud como “identidade de percepção". O psiquismo cria a percepção (mesmo que alucinatória) de um objeto que lhe garanta prazer, porém, perante ao fracasso da satisfação, o aparelho psíquico sofre uma modificação qualitativa que, segundo Kehl (2009), substitui a identidade de percepção pela "identidade mental": "Tal modificação acarreta para o funcionamento psíquico uma dimensão temporal: em vez de presentificar imediatamente o objeto faltante na forma de uma alucinação, o aparelho psíquico passa a representá-lo como aquilo que não está, mas deverá retornar" (Kehl, 2009, p.112).

Esta dimensão temporal, sob a forma de um objeto que não existe em primeiro momento, mas que pode retornar, ou seja, sob a forma da espera da satisfação, inscreve o sujeito psíquico. A primeira versão desta dimensão vem para o bebê que submete a urgência da satisfação de suas pulsões a uma certa demora, ou seja, ao seio que demora a se apresentar como objeto de satisfação das pulsões. O bebê, que sofre com a demora entre a satisfação da pulsão e o objeto apresentado produz uma representação desse mesmo objeto, para tentar anular o intervalo de tempo vazio, que gera sua angústia (Kehl, 2009).

A substituição do objeto que demora em aparecer pela sua representação faz o bebê ter contato não apenas com aquilo que é prazeroso, mas com uma realidade que é desagradável. Esta substituição, segundo Kehl (2009), dá ao aparelho psíquico uma capacidade de representar aquilo que ainda não existe, mas que pode vir a ser, ou seja, a noção de uma expectativa de futuro. 
O tempo é instituído para cada sujeito, de acordo com Kehl (2009), no intervalo entre a necessidade pulsional e a satisfação. Desta forma, segundo Fingermann (2008), a pulsionalidade se caracteriza como um ciclo entre um tempo que passa, irreversível, de espera da satisfação ou de realização da necessidade, e um que não passa, a atemporalidade que justifica o aspecto indestrutível e constante do desejo. O tempo que passa pode ser mensurado, como nos afirma as teorias do tempo físico, a partir do reconhecimento do intervalo, da duração e do momento em que acontece. Já o tempo que não passa, foge à nomeação, porque diz de uma ordem do desejo que, mesmo passando-se no tempo, permanece ali.

Chatelard (2008) nos alerta que o tempo perpassa as discussões em Psicanálise e "faz questão para o ser falante, para o ser do tempo" (p.10), uma "a-parição" do ser, um ser que para lidar com suas pulsões e desejos, demanda-se tempo. É neste sentido que, de acordo com Aparício (2008), durante o processo da análise surge, além do sentimento do tempo, uma consciência de sua existência no sujeito, levando-o a "tomada em conta que constitui, além do mais, a condição de possibilidade de um viver em seu tempo" (p.28). Durante o processo analítico o sujeito não só percebe que o tempo está por aí, em uma forma indizível, como também é ele próprio, a sua condição de viver, satisfazer e representar.

Ao falar do tempo pulsional, do tempo-subjetividade, que é o próprio ser, Teixeira (2008) alerta que este deve ser considerado não como um simples elemento da natureza, mas como um significante fundamental que estrutura a linguagem, como constituinte da subjetividade e sendo ela mesma. Sendo assim, "quando o homem cogita, quando sintomatiza, quando age, seja em que esfera for, goza do tempo. Nada existe fora do tempo, nada pode parar o tempo" (p.107).

É por conta da caracterização do tempo como sendo fundamental na estruturação da linguagem e do sujeito que Dunker (2008) diz que ele não é uma coisa ou um mero personagem. Segundo o autor, o tempo equivale àquilo que se apresenta, mas não está passível de 
representação, além de "algo que qualifica as ligações com os objetos na medida em que transforma o próprio sujeito" (p.129). Neste sentido, o tempo está na estruturação do sujeito, regula as pulsões, a dinâmica entre os conteúdos conscientes e inconscientes e a maneira como o sujeito lida com as escolhas dos objetos de satisfação.

Segundo Kehl (2009), para o ser humano, esta relação entre ligação com os objetos e espera da satisfação sempre depende de um outro ou de outras normas sociais para se realizar. As formas de organização subjetiva do tempo pulsional estão inteiramente ligadas aos grupos e ao processo cultural, que são modos de regulação social da pulsão. Nas palavras de Kehl: "são muito diversas as modalidades de satisfação que as diferentes culturas oferecem às exigências pulsionais, marcadas, entre outras coisas, por distintas maneiras de se vivenciar a passagem - também chamada duração - do tempo" (p.122). Vejamos, adiante, algumas formas possíveis de vivenciar os tempos psicanalíticos, de vivenciar a subjetividade, atreladas às exigências pulsionais marcadas pela realidade cultural.

\section{4. "Todos rumo ao acaso": Tempo-Subjetividade, Clínica e Cultura}

“There's a moment sailors call 'slack tide'. When the tide is neither coming in nor going out, but perfectly still. It's a moment frozen in time, when all is calm and peaceful. The only down side is that it passes so quickly. As much as we might like some things to remain suspended in time, they never do" - Scott Buck e Tim Hunter. ${ }^{7}$

Com a capacidade cognitiva de reconhecimento da passagem do tempo, a partir das sociedades mais avançadas, podemos perceber que a relação entre sujeito e cultura produz um

\footnotetext{
7 "Há um momento que os marinheiros chamam de 'maré calma'. Quando a maré não está nem vindo nem indo, mas perfeitamente imóvel. É um momento congelado no tempo, quando tudo está calmo e pacífico. A única desvantagem é que isso passa rapidamente. Por mais que gostássemos que algumas coisas permanecessem suspensas no tempo, elas nunca ficam" (tradução nossa).
} 
tempo-subjetividade. Sujeito, cultura e a noção temporal estão inteiramente ligados e é justamente esta junção que produz formas de existência subjetiva e organização social pautadas em uma relação com o tempo, que dita as normas de satisfação das pulsões, bem como o ritmo de um grupo.

O reconhecimento da passagem do tempo proporcionado pelo avanço no processo civilizatório e introduzido pelo sujeito como o desenrolar de sua própria história marcam, a partir das sociedades mais desenvolvidas, como vimos anteriormente, o que Kehl (2009) chama de transformação psíquica. A imbricação entre tempo e sujeito vai dizer de formas de uma necessidade vital de se aproveitar ao máximo o tempo disponível, que, nas palavras da autora, vão determinar as relações entre prazer e dor, de satisfação ou não das pulsões.

Desta forma, Kehl (2009) afirma que a temporalidade, inscrita no sujeito a partir de sua realidade social e de seu contato com a cultura, o sacrifica ao seu imperativo, situando o psiquismo numa função de atenção consciente. Esta função é marcada pela excessiva prontidão e estado de alerta, bem como pela antecipação do tempo futuro que já deixa de ser no instante seguinte. Sendo assim, a temporalidade experimentada pelo sujeito a partir das sociedades mais recentes - sobretudo a partir da Modernidade, como vimos - instaura a necessidade de viver cada segundo que se esgota em si mesmo.

Kehl (2009) situa a constituição temporal que marca a relação entre cultura e psiquismo na esfera do simbólico, ao falar do tempo enquanto uma categoria própria e natural do pensamento subjetivo, que o organiza em dados como os dias, meses e assim sucessivamente, numa série de marcações. Porém, sobretudo, a situa também no nível do Real, daquilo que não é passível de representação psíquica, do que diz da passagem do tempo em direção ao fim e à morte das coisas e, claro, do ser humano, um “transcorrer inexorável” através do qual cabe ao sujeito encontrar uma forma de lidar, já que este se faz incontrolável. 
É claro que este transcorrer vale não só para o ser humano, mas para toda matéria orgânica presente no planeta, porém, "a marcação abstrata do tempo [...] é vigiada pelo trabalho da consciência em sua função de adaptar o $e u$ às exigências da realidade - que não é outra coisa senão uma construção social” (Kehl, 2009, p.130). A consciência aliada à noção de um eu só se dá no ser humano que, a partir de sua realidade com o mundo externo, produz uma sensação do tempo como contínuo e linear, sensação esta permitida por transformações sociais que levaram a esta capacidade (Elias, 1998).

Hoje, para Soler (2008), o assunto do tempo aparece na clínica sobretudo por conta das formas atuais da cultura capitalista e dos meios de comunicação, que transformam o tempo num valor comercial que rege os gozos contemporâneos e criam demandas prontas a serem consumidas pelo sujeito. "Ser escutado durante um longo tempo a cada sessão, e sarar depressa, bem poderia ser a nova exigência de nossa época" (p.06), define a autora ao falar de uma ordem vigente do tempo que, por ser cultural, também aparece na clínica.

Os discursos do capital emergem pela e na clínica por conta de sujeitos que os carregam em seus sofrimentos e trazem deles certas marcas (Askofaré, 2008). Aliadas às manifestações da dor subjetiva, estão as políticas vigentes do tempo de produção e de consumo, nas relações interpessoais, no âmbito das organizações que exigem alta produtividade num pequeno intervalo de tempo e no plano ideológico carregado de propagandas que ditam o ritmo e produzem demandas (Checchia, 2008).

Gallano (2008) afirma que o eterno presente experimentado nos tempos atuais divide o sujeito entre "el menos de tiempo que le queda como sujeto, y el mas de goce que asedia al

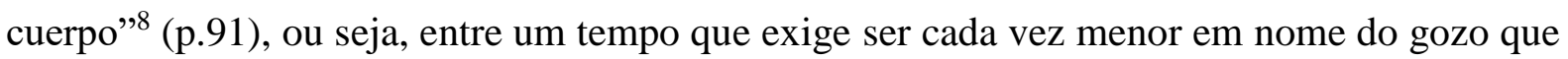
insiste em querer permanecer. Para o autor, esse impasse cruel entre a satisfação sempre pedida e a sua recuperação que não chega ao sujeito, faz sintoma.

\footnotetext{
8 "Ao menos de tempo em que permanece sujeitado, e ao mais-de-gozar que assedia ao corpo" (tradução nossa).
} 
A produção de sintoma causada pela contradição entre buscar uma satisfação além que não é alcançada se explica, como diz Brunetto (2008), por conta do ritmo e da ideologia do "tempo é dinheiro", "que faz com que a cada dia a avidez dos sujeitos - que é humana, demasiada humana, já que nenhum objeto pode tamponar a falta - seja diuturnamente reavivada por novos objetos que prometem o impossível" (p.121). É a partir da ordem do mercado capitalista que o autor relembra que sempre há a exigência de uma satisfação que ainda falta.

As manifestações dos sintomas do tempo-subjetividade na clínica em sua relação com a cultura do capital, da satisfação que está além e que falta, são as mais diversas possíveis, porém, sempre em busca de um tempo ou de uma satisfação perdidos, estejam eles no passado, no presente ou no futuro. Segundo Lombardi (2008), existem, nas neuroses, muitas formas de censurar o tempo, "de perdê-lo fazendo como se não existisse: a distração - matar o tempo -, a programação, o aborrecimento, a antecipação morosa do obsessivo, o muito rápido histérico, o muito tarde melancólico, o desencontro, a urgência subjetiva desorientada” (p.19).

Ainda nas formas de tempo-subjetividade na clínica contemporânea, Teixeira (2008) vai dizer de sintomas com a satisfação do presente, pelos maníacos, que desejam desesperadamente consumir tudo no hoje, ou pelos fóbicos, que buscam no agora uma margem de segurança. Outros, apresentam sofrimentos pela satisfação no passado, como os melancólicos, que se lembram com nostalgia do que já passou, se tornando escravos do que já foi ou deixou de ser. Há ainda aqueles que se satisfazem com o futuro, como os obsessivos que, ora se afligem pelo que está por vir, por não ter certeza do que vai acontecer ou pela falta de garantia em manter tudo sob controle, ora pela esperança em resolver seus problemas, na exaltação de um tempo adiado e procrastinado, que nunca chega de fato.

Atrelado à capacidade consciente de conceber o tempo enquanto linear, de se colocar como medida da passagem deste tempo e de, culturalmente, ter de se satisfazer com o mesmo, 
o sujeito se vê então numa situação muito difícil e de grande vulnerabilidade e sintomatização: como preservar a minha consciência e o meu eu, como se manter sujeito, neste tempo que sou eu, mas que transcorre sem o meu controle, contra a minha própria existência, e que me exige uma satisfação? A resposta que se tem encontrado, como podemos entender, é buscar alguma forma, alguma via através do sintoma, possibilitada pela cultura, de satisfazer as pulsões enquanto é tempo, enquanto há tempo, enquanto somos tempo.

\section{5. "Tenho tanto o que fazer": a Ação como Resposta à Vulnerabilidade}

"Vem, vamos embora, esperar não é saber. Quem sabe faz a hora, não espera acontecer" Geraldo Vandré

Kehl (2009), ao nos apontar para as modalidades de satisfação da pulsão que são reguladas pela vida em sociedade, ou seja, pela inserção do sujeito na cultura, remete-nos ao pensamento de Freud (1911/1996a), que destaca o pensar e o agir como saídas desta satisfação, como formas de aliviar o psiquismo do excesso de estímulos e buscar a satisfação exigida. Há a descarga motora, empregada, na forma apropriada à realidade, através da ação. Porém, quando há a coibição desta descarga, ou seja, a impossibilidade da ação, caracterizada pelo pensamento, dá-se ao psiquismo a capacidade de tolerar o aumento de energia psíquica enquanto o processo de descarga por meio da ação é adiado.

De acordo com Freud (1911/1996a) a descarga motora, cuja principal função é aliviar o aparelho psíquico do aumento de estímulos, recebe uma nova função ao se deparar com a condição da realidade, ou seja, a relação com a realidade externa modula os processos da ação. Neste sentido, a suspensão da ação, que se faz necessária momentaneamente, é rearranjada por meio do pensamento e da imaginação, para fazer com que o psiquismo seja capaz de tolerar os estímulos durante esta suspensão. 
Para Freud (1911/1996a), o aumento da importância da realidade externa aumenta, também, a relevância dos órgãos do sentido para trabalhar em conjunto com o mundo e a consciência. É papel destes órgãos consultar o mundo exterior para que a consciência seja capaz de conhecer este mundo quando surgir no psiquismo uma necessidade que não se pode adiar. Esta capacidade procura os dados da realidade em vez de aguardar que estes se manifestem nos sentidos, sendo assim, há a possibilidade de se criar um "sistema de registro", que tem por responsabilidade guardar as consequências desta análise periódica da consciência sobre o mundo externo. Sobre estes papéis da consciência, o autor os relaciona sob as funções da atenção e da memória.

Kehl (2009) afirma que o saber produzido através do pensamento, em suas funções de atenção e memória, como define Freud (1911/1996a), depende não só desta capacidade de a consciência se lançar para o mundo externo, mas também da relação entre a duração e a conclusão desse impulso, uma relação temporal que define o trabalho da representação psíquica sobre o mundo externo e da produção de marcas mnêmicas dos objetos. Contudo, a autora denuncia que o caráter urgente da vida social atual inscreve à experiência subjetiva do tempo uma temporalidade reduzida à "sequência de instantes que comandam sucessivos impulsos à ação, não sustentados pelo saber que advém de uma prévia experiência” (p.116). Além disso, esta temporalidade se faz "vazia, na qual nada se cria e da qual não se conserva nenhuma lembrança significativa capaz de conferir valor ao vivido" (p.116).

Sendo assim, Kehl (2009) diz que as formas de se vivenciar e experimentar o tempo na atualidade impedem com que o psiquismo trabalhe em sua capacidade total, reduzindo a atenção e a memória a "encontros falhados" com o mundo real, reduzindo-as à função de ligar o psiquismo ao eterno presente. A atenção e a memória são entendidas, respectivamente, como processos capazes de oferecer ao sujeito estados de prontidão e antecipação, que não dão tempo para a produção significativa de sentido sobre a realidade. É assim, então, que, na 
contemporaneidade, o impulso à ação, mediado pela prontidão e pela antecipação, tem a primazia sobre os processos do pensamento e, sobretudo, sobre a relação entre duração e conclusão dos processos cognitivos. Desta forma, pode-se afirmar que, a suspensão parcial e momentânea da ação por meio do pensamento, defendida por Freud (1911/1996a) se faz, cada vez mais, impossibilitada pelo ritmo da vida social atual.

Se, como afirma Kehl (2009), o intervalo entre a necessidade pulsional e a sua satisfação pode ser entendido através do pensar e do agir e, sendo o impulso à ação o registro mais importante da relação temporal que se tem nos tempos atuais, como fica o intervalo da satisfação em uma sociedade em que não se pode intervalar? É por isso que, segundo Birman (2012), o registro da ação também está passível de mal-estar, ou seja, da não satisfação das pulsões. Segundo o autor, o mal-estar evidenciado por Freud, que estava centrado no conflito psíquico, na dinâmica entre as pulsões e as interdições morais da cultura, agora, na contemporaneidade, se configura enquanto dor, nos registros do corpo, da ação e das intensidades.

Ao falar da ação como forma de registro pulsional, Birman (2012) diz de uma necessidade contemporânea de agir, como forma de resgate do tempo perdido entre a necessidade e a satisfação, tempo este cada vez menor. Segundo ele, pela análise da ação, podemos perceber uma transformação subjetiva que acompanha o processo de modificação histórica entre um estilo de vida que, até então, era pausado e reflexivo, pautado no pensamento, para a aceleração do sujeito que define os tempos mais atuais, marcados pela ação. Não é à toa ouvirmos demandas imperativas como "dê tempo ao tempo", como forma de denunciar o ritmo vertiginoso das relações temporais da contemporaneidade.

O tempo não acelerou em si, mas sim a sua percepção: não é o passar do tempo que está mais veloz, mas o tempo-subjetividade, por conta das transformações sociais, políticas e econômicas da contemporaneidade. De acordo com Birman (2012) o ser que antes era 
interiorizado e reflexivo se transforma no ser exteriorizado e performático, que, antes de mais nada, deseja agir. Este sujeito, segundo Kehl (2009), se encontra num grande estado de empobrecimento de sua vida pois a vigilância de sua consciência o dominou de tal forma que não consegue mais se desligar deste estado de alerta e produzir realidades significativas, que demandam tempo.

Desse modo, o que importa para o sujeito contemporâneo é agir, mesmo que essa ação não dê conta do resgate do tempo perdido ou seja carregada de uma falta de sentido, de um empobrecimento do conteúdo da vida do sujeito. Como nos anuncia Birman (2012):

[...] a hiperatividade se impõe. Age-se frequentemente sem que se pense naquilo a que se visa com a ação, de forma que os indivíduos nem sempre sabem dizer o que os leva a agir. O sujeito da ação tem a marca da indeterminação. No cogito da atualidade, o que se enuncia ostensivamente é: agir, logo existir. O agir é o imperativo categórico na contemporaneidade (Birman, 2012, p.82).

As subjetividades contemporâneas, ou ainda, as formas do intervalo da satisfação pulsional na contemporaneidade, são marcadas pelo excesso (na sua presença ou na sua ausência), que empurra o sujeito para a ação (ativa ou passiva). Existe uma relação contraditória: o excesso só pode ser eliminado através de sua exteriorização, carregando uma ação ativa, ou seja, por meio do ato, caso contrário, o sujeito se afundaria em mal-estar. Porém, agir em excesso também é uma forma de não satisfação pulsional, porque nem sempre tem sentido, é uma ação pela ação (Birman, 2012), pois é um agir de forma passiva, um fluir de acordo com a maré, "deixando a vida me levar".

O autor chama de "fundo difuso e indeterminado" esta contradição, que define algumas das modalidades do agir contemporâneo. A constituição temporal da atualidade produz formas de satisfação que faz com que os sujeitos não consigam mais conter o excesso no seu interior, não consigam mais abarcar toda a pulsão e muito menos esperar pelo intervalo de sua 
satisfação, para ser capaz de simbolizar e transformar a pulsão em uma ação carregada de sentido e significado. Diante deste entrave, Birman (2012) afirma que a descarga pulsional acaba se impondo na forma de "manifestações emocionais incontroláveis", como vemos através da violência exacerbada que toma conta das relações atuais, do consumismo desenfreado de drogas e produtos comestíveis, dos corpos que já não aguentam mais o ritmo e a falta do intervalo.

Ao dizer da ação enquanto saída para a satisfação dos desejos, Freud (1930[1929]/1996f) caracteriza o "homem de ação" como aquele sujeito que tenta expressar e testar a sua força através de seus atos, buscando, da maneira mais possível, se satisfazer de forma real a partir da sua relação com o mundo externo. Segundo ele, a ação nada mais é que uma tentativa do ser humano no caminho de encontrar a felicidade, ou ainda, o prazer.

A ação é uma das formas de se buscar uma "salvação" quando o assunto é a realização dos desejos, ainda que estes não sejam plenamente satisfeitos. O agir, neste sentido, se configura como sinônimo de fazer, "fazer a vida", de correr atrás do tempo perdido que foi gasto no intervalo da necessidade à satisfação. Intervalo este cada vez menor no mundo contemporâneo, por conta das exigências de um tempo que, como diz Barcelos (2006), não dá tempo, que produz um presente sem duração, sem espessura.

Fazer é, então, resgatar o tempo perdido e garantir, também, o tempo que não se pode mais perder. Porém, este fazer, esta ação, não se sustentam enquanto sentido, pois, dizendo de um tempo enquanto real, impossível de representação, não se pode garantir algo que nos passa e nos escapa.

A salvação que nunca se alcança pela ação é a marca do mal-estar contemporâneo denunciado por Birman (2012), do qual o sujeito precisa ser salvo, como nos aponta Freud (1930[1929]/1996f). Neste ponto, nos perguntamos: fazer para ser salvo de quê? O próprio Freud responde a esta pergunta ao dizer que o ser humano encontra em sua caminhada na vida 
três grandes fontes de sofrimento, advindas das forças superiores da natureza - que às vezes são por ele denominadas de Destino - da fragilidade do próprio corpo e das relações sociais. De acordo com ele, estas fontes de sofrimento nos forçam a reconhecer e a submeter ao inevitável, compositor do destino humano, do qual não conseguimos escapar ou controlar, sendo assim, "nunca dominaremos completamente a natureza, e o nosso organismo corporal, ele mesmo parte dessa natureza, permanecerá sempre como uma estrutura passageira, com limitada capacidade de adaptação e realização" (Freud, 1930[1929]/1996f, p.93).

A ação é uma tentativa de resgate do tempo perdido entre a necessidade e a satisfação e uma maneira encontrada pelo sujeito de tentar abrandar suas fontes de sofrimento advindas do transcorrer do tempo, representadas pelas forças da natureza e pela transitoriedade do corpo. Teixeira (2008) vai afirmar que, para o sujeito, "nada mais real e demasiadamente humano que a angústia em sua relação com o tempo" (p.107). Entretanto, Aparício (2008) nos adverte que o simples reconhecimento do tempo não necessariamente gera angústia, mas o fato deste estar entrelaçado com o desejo humano.

É nesta perspectiva que Teixeira (2008) vai dizer do tempo que exige ligação aos objetos de satisfação sendo, ele mesmo, um objeto. O tempo que demanda satisfação é também o tempo pelo qual se busca satisfazer, o tempo pelo qual se busca recuperar e dar sentido à vida. Desta forma "podemos dizer que o tempo não apenas faz sintoma, mas que ele é sintoma" (p.107), trazendo o sujeito, de uma forma ou outra, à questão da morte e à aproximação com a mesma, já que não podemos encará-la face a face. Assim, Aparício (2008) afirma que falar do tempo, enquanto desejo - e sintoma - é falar, inevitavelmente, da figura da morte, uma vez que se busca satisfazer o tempo que distancia o sujeito do encontro com o fim.

Ainda que a ciência racionalista da Modernidade tenha tentado afastar o ser humano e seu corpo da natureza, como uma parte privilegiada da existência, Freud (1930[1929]/1996f) resgata e retoma o lugar do corpo e da vida humana como parte da própria natureza. Se o ideal 
racionalista pretendeu controlar o tempo como uma força da natureza desconectada da vida, ele faz o caminho inverso: reconhece como inevitável a nossa condição temporal, unindo o ser humano com a sua natureza, que não é passível de controle ou de possibilidade de fuga do imprevisível. Se o ideal racionalista tentou maquiar e alvejar o lado obscuro e vulnerável do ser humano através da redução da natureza a dados objetivos, o autor afirma e nos adverte da impossibilidade deste mascaramento, da impossibilidade de controlar a vulnerabilidade e a transitoriedade da existência. Diz ele:

Os homens se orgulham de suas realizações e têm todo direito de se orgulharem. Contudo, parecem ter observado que o poder recentemente adquirido sobre o espaço e o tempo, a subjugação das forças da natureza, consecução de um anseio que remonta a milhares de anos, não aumentou a quantidade de satisfação prazerosa que poderiam esperar da vida e não os tornou mais felizes. Reconhecendo esse fato, devemos contentar-nos em concluir que o poder sobre a natureza não constitui a única precondição da felicidade humana, assim como não é o único objetivo do esforço cultural (Freud, 1930[1929]/1996f, pp.94-95).

É reconhecendo que o simples controle sobre a natureza não se reduz enquanto a única fonte de satisfação e felicidade do ser humano, em sua vida cultural, que Freud vai dizer que a própria vida em cultura possibilita uma carga de defesa ao sujeito. Portanto, o controle da natureza e, consequentemente, do tempo como força natural, diz de uma tentativa de defesa do próprio sujeito, para tentar se amparar perante a sua condição finita. De acordo com Freud (1930[1929]/1996f) reconhecer a condição finita é um dos fatos que faz da vida uma tarefa árdua e nos impõe sofrimentos e condições difíceis de serem superadas. Continuando nesta linha de pensamento, o autor defende que a própria ciência, enquanto produto da realização humana, constitui também uma tentativa de tornar a existência, a vida cultural, menos árdua. 
Freud (1927/1996e) reconhece, então, que o fator psicológico da vida em cultura é de fundamental importância para a manutenção da mesma e, claro, para a vida humana. Se antes podíamos pensar que a essência do controle da natureza servia apenas para a finalidade de adquirir riquezas para a construção e desenvolvimento da civilização, com Freud, esse caminho se desloca do material para o mental.

Portanto, mais importante do que fazer funcionar o projeto de civilização e suas tecnologias, ao qual pretendem as sociedades e grupos humanos, é defender o ser humano contra as forças incontroláveis da natureza. O simples fato da construção e manutenção da civilização já se configura como uma forma encontrada nesta tentativa de defesa. Sendo assim, a civilização e os próprios seres humanos possuem o que Freud (1927/1996e) chama de tarefa múltipla, que seria consolar o narcisismo humano, ameaçado pelos terrores do universo, e encontrar uma resposta para a curiosidade que move a vida humana em busca de uma resposta do sentido de sua existência.

Com o deslocamento material para o nível mental, ou seja, com o reconhecimento de que o controle da natureza funciona muito mais para abrandar o desamparo humano do que para gerar possibilidades de manutenção da civilização, Freud (1927/1996e) denomina de "humanização da natureza" este movimento que tem por finalidade dar um fim, ou pelo menos uma redução, no sentimento de vulnerabilidade do ser humano frente às forças naturais. É por meio da ação e, consequentemente, da criação humana - entendendo a ciência enquanto uma criação - que se pode tentar diminuir a angústia causada pelo reconhecimento de que o ser humano não tem muito o que fazer perante todas as condições do universo.

A importância da mudança do nível material para o mental também é entendida por Mészáros (2007) que vai dizer que a urgência do nosso tempo alcançou não só os sujeitos, mas como a própria espécie humana, na sua vida social, subjetiva e corpórea. É por isso que "algumas tecnologias produtivas poderosas e o uso potencial ao qual elas podem ser postas 
trazem consigo a necessidade de tomar decisões extremamente difíceis e talvez mesmo irreversivelmente perigosas, que envolvem diretamente a questão do tempo” (p.38).

Nesse sentido, o ser humano se encontra num lugar de extrema fragilidade, já que, em nome do progresso social e do avanço tecnológico, deixa de lado o próprio caráter humano e desconhece suas fraquezas e limites, atravessados por demandas capitalistas. Migdalek (2008) relembra Freud e seu texto "Mal-Estar na Civilização" ao denunciar que a ciência e a tecnologia trazem consigo e na criação de seus objetos e instrumentos "nuevas formas de padecimiento", (p.109).

Precisamos, por isso, resgatar um sujeito que se vê numa tarefa aparentemente paralisante, que reconhece seu estado de incapacidade de controle total da natureza e de consequente encontro brusco com o seu desamparo. Como afirma Barcelos (2006), precisamos experimentar novos gordos intervalos, com espessura, com duração, para dar conta de uma subjetividade paralisada, que vive em uma ordem temporal sem gosto, em que "tudo circula, e, ao mesmo tempo, tudo parece petrificar-se" (p.69). Portanto, como reconhece Freud (1930[1929]/1996f), este encontro com o desamparo e com a impossibilidade de controlar a natureza não deve ser encarado como paralisador, mas como condição que aponta o caminho para a nossa ação e realização, uma vez que "não podemos afastar todo sofrimento, podemos afastar um pouco dele e mitigar outro tanto" (p.93).

De acordo com Lombardi (2008) a proposta psicanalítica de ir de encontro com o tempo - configurado enquanto desejo e sintoma - é pretensiosa. Porém, manejar o tempo significa, também, reconhecer que "por mais reduzida que seja a margem de escolha que nos resta, ali está nosso desejo, nesse lapso limitado pelo ato como renovação" (p.19). É por isso que o processo analítico não se faz pela redução do sujeito a um ser da morte, a um ser que precisa lembrar o tempo todo que irá morrer, mas pelo seu reconhecimento de ser do ato, "pela

\footnotetext{
9 "Novas formas de padecimento" (tradução nossa).
} 
renovação da experiência já vivida da descontinuidade temporal, que marca um antes e um depois, revelando o aspecto mais real do tempo: a impossibilidade de retroceder" (p.19).

A ação não deve ser encarada como perspectivas doentias da nossa relação com o tempo (Barcelos, 2009), ou como uma tentativa de resgate do tempo perdido entre a necessidade e a satisfação, uma ação difusa e sem propósitos, como elucida Birman (2012), nem como forma de se lamentar pelo passado ou alimentar o presente com sonhos futuros. É o encontro com o aspecto real do tempo que deve marcar o ato, como meio de afirmar o presente em sua duração, um "presente que mostra dignidade, valor e grandeza da vida na hora em que ela acontece" (Barcelos, 2009, p.58).

É aqui que nos deparamos com a Arte, como uma forma de mitigar um outro tanto do sofrimento humano, através do encontro de uma produção de significado pelo manejo do tempo, e também de reconhecer este sofrimento que vai além da vontade e da expectativa humanas. Caminharemos de mãos dadas, mais especificamente, com a música de Pitty, para encontrarmos um sentido ou uma composição simbólica possível de dizer deste sofrimento ao mesmo ritmo em que o reconheceremos enquanto condição intrínseca da constituição temporal da relação entre sujeito e cultura. 


\section{CAPÍTULO III}

“COM TODA BELEZA E ABOMINAÇÃO”: O TEMPO-SUBJETIVIDADE NA MÚSICA DE PITTY

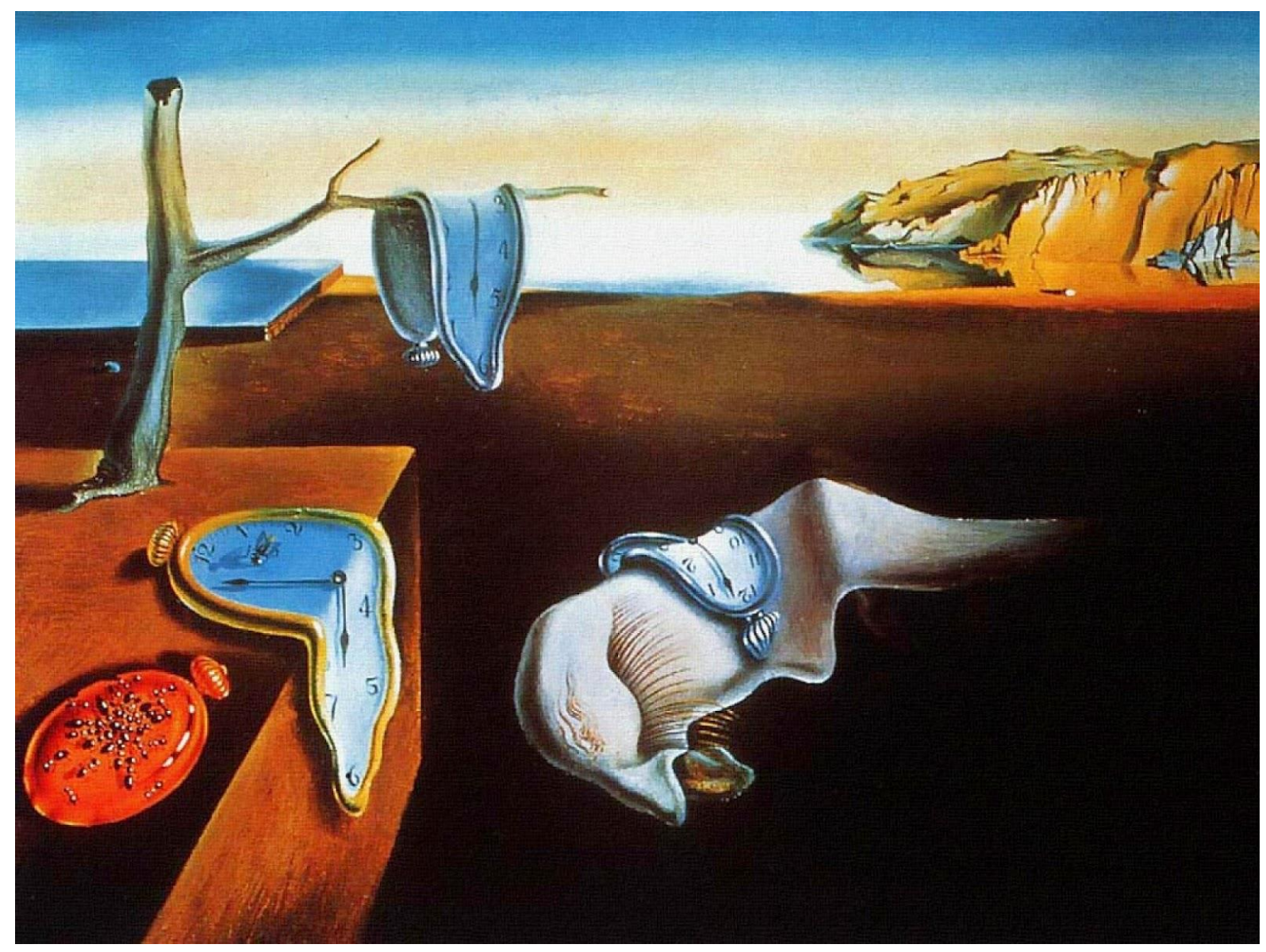

A Persistência da Memória - Salvador Dali 
"Eu gosto de música que sangra": é o que fala Pitty, ao revelar seu gosto musical, o teor de suas composições e o que a leva a escrever sobre aquilo que há de mais desconhecido e obscuro em si mesma. O que faz a música sangrar senão o próprio sujeito, que se depara com o incerto e com a necessidade de encarar a vida? É deste sujeito que Pitty fala e é ele quem ela traz em suas obras: um sujeito descontente, que se percebe diante do que lhe é novo e que se vê, muitas vezes, incapaz diante de fatos. Podemos encontrar em suas músicas um sujeito que se depara com uma configuração do mal-estar contemporâneo, pautado na relação com o real do tempo.

Atrelada à própria transformação e amadurecimento da pessoa Pitty, sua música e suas inspirações também se modificaram. Podemos ouvir a cantora dizer: "Passei várias fases, várias fases. Eu comecei ouvindo metal, metal mesmo. Depois eu encontrei o grunge e paralelo a isso o hardcore. E aí tudo o que não era isso era horrível, era música de fresco". Com o passar do tempo, a medida que ia ficando mais velha, a cantora percebia que seu leque ia se abrindo: “É, depois eu comecei a ouvir muito indie, que no começo eu tinha um puta preconceito: 'fica aí chorando'... Era muito, muito dura". Ainda percebendo certa resistência a novos modos de criação e de formas de expressão, Pitty diz que ao longo do tempo foi "quebrando os radicalismos assim, a vida foi me levando pra [...] Depois que você quebra essa onda infantil, um pouco né, de você achar que 'Ah! As coisas são assim, o que não é isso é ruim', você começa a ver". ${ }^{10}$

Podemos nos perguntar, então, para onde a vida foi lhe levando? O que ela começou a ver depois de todas estas transformações? Agora Pitty nos diz que "música não é rótulo, é sentimento. [...] quando eu entendi isso, meu mundo virou de cabeça pra baixo. [...] aí eu joguei isso tudo fora e hoje pra mim não importa; importa ouvir e bater. No final das contas eu não

\footnotetext{
${ }^{10}$ Falas retiradas da entrevista para o canal MTV durante a produção do programa "Música.doc" em 2015. Disponível em: http://www.mtv.com.br/programas/destaques/musicadoc/videos/pitty-1-1201581/. Acesso em: 17 de maio de 2015.
} 
gosto de rock, ou disso, [...] eu gosto de música que sangra, eu gosto de música que bate um bagulho e que mexe. [...] tem que bater"11.

O "isso" que foi preciso ser jogado fora para se fazer entendido diz respeito à resistência de criar uma música que mexe com o que há de desconfortável no sujeito. Se até então seus estilos musicais preferidos - metal e hardcore - diziam de um rótulo em que cantores e compositores têm que ser, como define a cantora, "muito, muito dura", com o estigma de comportamentos agressivos, ela reconhece que música não necessariamente tem a ver com manter uma imagem de rebeldia. Se até então ela tinha que parecer dura, firme, inabalável, agora ela entende que não é o sujeito quem tem que bater na música, ou destruir os instrumentos enquanto performa, mas o contrário: música é sentimento, é a música quem bate. Se antes ela criticava um sujeito "fresco" que ficava chorando, agora ela afirma essa postura de reconhecer a dor e aquilo que machuca.

As batidas da música da cantora têm o objetivo de alcançar os sentimentos, alcançar um "bagulho". Bagulho esse que resgata aquilo que há de mais profundo e visceral, aquilo que há de mais inquieto, como quem diz que a quietude e o conforto não são dignos de uma inspiração, pois marcam um lugar comum e já se encerram em si mesmos. O caos, o turbilhão de desordem, é o que a move a escrever, a cantar e a expurgar toda a sua zona de conforto. Neste sentido, as batidas que Pitty toma para si querem, além de bater em algo no sujeito, constituir um novo tempo, um tempo que afirma que doer também é um possível para aquele sujeito que, até então, se encontrava numa posição de defesa contra o real do tempo.

Essas batidas nos lembram ao que se refere Mezan (1998) sobre o "um a mais de excitação" que move o trabalho do artista que, por meio da arte, se lança e nos lança em experiências: a experiências que fogem e escapam à rotina, e se diferenciam daquelas

\footnotetext{
${ }^{11}$ Falas retiradas da entrevista para o canal MTV durante a produção do programa "Música.doc" em 2015. Disponível em: http://www.mtv.com.br/programas/destaques/musicadoc/videos/pitty-1-1201581/. Acesso em: 17 de maio de 2015.
} 
cotidianas que não têm força suficiente para gerar a faísca e dar vida ao sentimento. A experiência confortável à qual todos estamos acostumados, em nossa vida diária, nada consegue fazer de novidade, diferente daquela experiência inquieta, que nos convida e lança, às vezes sem avisar, à confusão. Assim, um afeto intenso, fora do ordinário e corriqueiro, "que não se enquadre nos esquemas habituais do sujeito, que transborde os limites do cotidiano, parece indispensável como disparador da necessidade artística” (Mezan, 1998, p.113). É este a mais de excitação que podemos perceber em Pitty (2009a) ao dizer daquilo que precisa ser exteriorizado: "Então sai, deixa correr/Toda a água contida/Então sai, deixa correr/Toda mágoa velada é água parada/E uma hora transborda".

No prefácio do livro "Pitty: cronografia: uma trajetória em fotos" (Pitty, 2014a), Pimentel define a cantora como "sempre orgânica", ao dizer de uma pessoa e uma artista que se coloca por completo, seja na vida, seja no processo de criação. Esta definição nos remete às palavras de Barcelos (2009) ao dizer do corpo intensivo, um corpo que "apreende o mundo como sensação e estranhamento" (p.60). Pitty se coloca como "sempre orgânica" porque escreve aquilo que vive e vive aquilo que escreve, estranhando o que lhe perpassa o corpo orgânico, carregando "tanto suor em cada vírgula em que participa” (Pitty, 2014a).

É esse suor em cada vírgula, o sangue que escorre da música, que se configura como o afeto fora do comum, que Pitty usa como "disparador" de sua necessidade de criar, quando se depara com afetos agradáveis ou não, que transbordam e exigem uma linguagem. É por isso que sua obra é experimentada com identificação e desassossego, ao mesmo tempo, pois diz do afeto compartilhado pelo humano, bem como de algo que foge da experiência agradável: "para se transformar em ouro você tem que passar por outras fases. [...] um monte de perdas, e de ganhos também. [...] a vida é assim, temos que passar por ela. O bom é transformar o ruim em 
bom, porque não tem jeito. [...] quero transformar tudo o que é ruim em trampolim. Dor tem para todo mundo. O que você faz com o que te acontece? Como você usa?"12.

A transformação do afeto, da alegria que transborda e da dor que consome, é o gatilho de criação de Pitty. Esta transformação do afeto em arte é definida por Mezan (1998) como a verbalização do sentido, que propicia um distanciamento e uma superação da experiência afetuosa. Segundo Barcelos (2009), ao fazer música, “o artista aprende a dar melodia à verdade do que viu, viveu, sentiu" (p.65), ao transformar seu afeto em música, este ganha uma nova significação e "conquista outras durações", fazendo com que o artista crie e resista ao libertar a própria vida das "prisões culturais".

A música de Pitty dá voz àquilo que até então não tinha como ser dito dentro de si, pois ela canta um tempo que se apresenta e que escapa, ela canta o que lhe alegra e também o que lhe dói, e por meio deste ato, ela transforma seu afeto naquilo que não pode ser encaixado em um discurso pronto. Ela rompe com os ideais do conforto que tanto prendem os sujeitos e mascaram seus afetos ao dizer que "Ele [meu pranto] me liberta na hora/No momento em que eu boto pra fora/O que já não me serve vai embora" (Pitty, 2009a).

E o tempo, onde fica nisso tudo? Como se dá o tempo-subjetividade nos afetos e nas palavras de Pitty? Como veremos, o tempo é dito pela cantora em suas diversas formas: na reprodução de um ideal temporal do modo de produção capitalista, no tempo acelerado experimentado pelo sujeito e na urgência em estar vivo. Há também, um discurso da resistência a essas políticas do tempo, através do apelo a uma pausa ou a uma redução do ritmo, ou na afirmação, ainda que dolorosa, das mazelas humanas e do fim do tempo como parte do encerrar da própria existência.

\footnotetext{
12 Trecho de entrevista concedida à edição 93 da revista Rolling Stone em junho de 2014. Disponível em: http://rollingstone.uol.com.br/edicao/edicao-93/pitty-\#imagem0. Acesso em: 15 de junho de 2014.
} 
Encaradas sob o olhar manifesto e desvelado enquanto transformação dos afetos, podemos dizer que as palavras de Pitty vêm ao encontro das palavras de Mezan (1998). Este, ao se referir sobre o papel da arte, diz que ela é "abalo às certezas costumeiras, ao deslizar sem obstáculos da existência, à tranquilidade de estar no mundo" (p.113). Pitty denuncia um tempo que exige, que controla os ritmos, de uma forma que revele os "obstáculos da existência" que prendem os sujeitos a modos de vida definidos e cristalizados. Um tempo que se faz no sujeito e marca seus desejos, um tempo que diz da incapacidade do ser humano para controlar a sua natureza finita, rompendo com a "tranquilidade de estar no mundo".

\section{1. "Resistindo a me dissolver", sangro e suspendo - uma oitava abaixo e outra acima}

A capacidade social e cultural que a humanidade adquiriu ao lançar suas expectativas para um tempo futuro delineia suas pulsões (Elias, 1998), isto quer dizer que, como nos relembra Kehl (2009), as pulsões estão intimamente relacionadas às saídas possíveis oferecidas pela vida em cultura. Percebemos esta problematização em Pitty (2005c), que também está inserida em sua própria cultura, que confirma nossa trajetória temporal quando questiona “... e depois, então,/que conquistar o último desafio/quando aprender a voar/quando achar que já tem tudo/o que vai querer depois?".

Esta forma de relacionar o tempo através do desejo revela o caráter do tempo enquanto subjetividade, o que, como vimos, gera angústia pelo reconhecimento da própria finitude. A reificação da vida humana enquanto objeto de medida do tempo fica clara em Pitty (2003c), que espera não deixar "nada pra depois, não deixe o tempo passar/Não deixe nada pra semana que vem/Porque semana que vem pode nem chegar". O reconhecimento da existência de uma "semana que vem" nos exige a aproveitar o tempo enquanto somos tempo, porque este tempo pode não chegar, o que significa dizer que a vida pode não ser, que ela pode acabar a qualquer 
momento. Já que "Nós não temos todo o tempo do mundo", a cantora insiste em se preocupar que "Esse pode ser o último dia de nossas vidas/Última chance de fazer tudo ter valido a pena" (Pitty, 2003c).

Aproveitar o tempo enquanto é ou enquanto somos tempo, por ser um tempo que pode não chegar, diz, também, do paradoxo temporal: dizemos de um tempo que passa, que exige aproveitamento, um tempo marcado pelo decorrer do calendário, um tempo intervalo entre o hoje e o amanhã que pode ou não chegar, sendo, sobretudo, um tempo que constitui história. Contudo, dizemos também de um tempo que pode não ser, um tempo que, por passar, pode acabar, pode parar a qualquer momento, deixando de escrever história. É neste paradoxo que se encontra o sujeito contemporâneo, vivendo a angústia de uma ameaça temporal que não se sabe bem o que é. Uma ameaça que exige o fazer história, através do tempo que está sendo contado, porém que escapa ao sujeito, que dá a sensação de que a sua própria história pode não chegar e não está sendo escrita, como se já não estivesse sendo feita cotidianamente.

Os chamados processos civilizatórios permitiram a inserção da vida como desenrolar do tempo e reforçaram o caráter regulador deste tempo nas relações humanas. Sendo assim, vimos como o ser humano busca, através de várias maneiras, controlar as passagens do tempo, como tentativas ou ilusão de poder controlar, também, a sua natureza finita. Mas quando há um tempo cultural em que o próprio ser humano é transformado em medida de tempo, ele não pode escapar da experiência de "viver na pele", sangrar, sobre esta passagem. É aí que Pitty (2003e) nos desafia: "Eu quero ver quem é capaz/De fechar os olhos e descansar em paz". Na realidade cultural atual em que a vida é a própria passagem do tempo - e que o tempo se torna a própria existência - e que não nos dá tempo de esperar, não podemos, então, fechar os olhos para descansar em paz.

O descansar em paz não é entendido como a morte, nem como o tempo livre, oposto ao tempo do trabalho, mas como forma de viver um tempo contrário ao do eterno presente. Um 
tempo em que o presente se faz digno de experimentação, que permita ao sujeito viver a agir sem se preocupar com o que vem depois, um presente com espessura, nas palavras de Barcelos (2006; 2009). Quando Pitty (2003d) canta “Quero uma fermata que possa fazer/Agora o tempo me obedecer/E só então, eu deixo/Os medos e as armas pra trás" percebemos a tentativa de buscar esse descanso, essa possibilidade de vivenciar um presente prolongado e consistente. Não é uma tentativa de aumentar o tempo de vida ou de se aproveitar ao máximo cada segundo, mas um suplício por um modo possível de poder cantar uma oitava acima e uma oitava abaixo do tom vigente e emergente da atualidade, uma tentativa de se reescrever na sua própria história, para que saiamos do que Mészáros (2007) chama de vida de tudo ou nada.

Desta forma, ela poderia deixar para trás seus medos e armas, ou, como vimos, suas angústias, sintomas e defesas, em relação ao desenrolar do tempo que significa, também, o desenrolar da própria vida, aproximando-a do fim. Com a fermata, suspendendo o tempo, ela pode suspender, também, a necessidade de agir de forma incontrolável para que cada segundo seja vivido ao máximo. Ela suspende o ritmo e, enfim, pode fechar os olhos e descansar, já que o recurso da fermata permite não só a suspensão, como o manejo do tempo de acordo com o desejo do artista.

O pedido pela fermata e pela suspensão também denuncia a percepção acelerada do tempo nas sociedades mais atuais. A cantora pede uma pausa, um prolongamento da duração, um momento para respirar entre uma nota e outra, um momento para significar o intervalo entre a necessidade e a satisfação (Kehl, 2009). Intervalo que tem sido cada vez mais perdido em nome do ritmo vertiginoso das relações. Intervalo este definido por Barcelos (2006) como uma pausa intensiva, que não diz da parada de movimento ou de ação, mas da possibilidade de experimentação do tempo.

A configuração do tempo enquanto subjetividade e a tentativa da ciência racionalista moderna de quantificá-lo e criar categorias de medição, como forma de prever e controlar o 
seu desenrolar, abre espaço para a criação de uma ilusão de que é possível dominar a natureza e suas grandezas, controlando a própria existência (Elias, 1998; Freud, 1927/1996e), como nos diz Pitty (2003e): sujeitos “bem certos que a verdade cabe na palma da mão". Isso lança a impressão de que a eventualidade, aquilo que não é esperado, é uma emboscada à espreita, contra a tranquilidade do sujeito, e é um fator que, como relembram Morin (1977/2009) e Oliva-Augusto (1995), deve ser isolado a todo custo.

Em Pitty (2003b), isso se faz presente ao dizer que "Parece um dia tão normal/Mas em cada esquina você pode vacilar, e então/Vê se se cuida, rapaz/Então, estamos quase quites/Se ainda não percebeu, isso é uma/Emboscada, armadilha”. Isso que é tão bem explicado por Figueiredo e Santi (2006) e por Cantarelli (2013) quando falam dos estranhos, sobretudo a partir da Modernidade, palco da experimentação de uma possibilidade de autonomia perante o grupo social. É neste cenário de descobertas de novos territórios e desenvolvimento científico que o sujeito moderno se encontra com o novo, com o diverso, tentando lutar para manter a sua originalidade e unidade, para não se perder dos referenciais.

O reconhecimento da inevitabilidade dos episódios eventuais leva às experiências de angústia frente ao real, ao tempo que não é agora mas pode ser a qualquer momento, um tempo que faz a realidade caótica do sujeito. Se a eventualidade é algo do qual não se pode escapar, mas que, mesmo assim, vive-se tentando prevê-la para evitá-la, dizemos de um real do tempo paradoxal: um tempo intervalar que passa e, ao mesmo tempo, um tempo inconsciente que não passa, que mantém o desejo e a exigência de satisfazer com o tempo.

Um tempo que passa, porém que nos escapa, que nos foge: neste sentido, o tempo é história para o sujeito que não se percebe na sua própria história. O tempo que não é agora, que, entretanto, pode ser agora, a qualquer momento. É um tempo que congela e exclui a experiência do passado e do futuro - da história do sujeito - pois reduz tudo a uma angústia de ameaça do presente, a uma angústia em que algo está para acontecer sem acontecer. 
E como sair desse real que angustia, que não dá sossego? O sujeito procura, cada vez mais, negar suas dores e buscar por formas de aliviar o sofrimento, negar essa angústia de algo incerto. A “arte de viver", como define Freud (1930[1929]/1996f), pela qual o sujeito tenta se tornar independente do Destino, diferente da arte que traduz e liberta a clausura cultural, pode levar o mesmo a buscar paliativos para a angústia contra esta fonte de sofrimento. Ou nas palavras de Pitty, o sujeito pede "um remédio pra amargura/Ou as drogas que vêm com bula" (Pitty, Duda, Joe \& Martin, 2009a). Não é à toa que, cada vez mais, aumentam as vendas e o número de pessoas consumidoras de drogas, legais ou não, como forma de alívio ou fuga da realidade, além de psicofármacos que prometem uma felicidade instantânea ou a redução da ansiedade, controlando o sujeito e o tornando apto para a vida em sociedade.

Para além dos remédios para amargura ou das drogas que vêm com bula, temos também a literatura de autoajuda e os cosméticos, como nos lembra Barcelos (2006). Produtos que confortam o sujeito com frases motivacionais como "aproveite o agora", "viva como se não houvesse amanhã", ou ainda, receitas de "como ser feliz" ou "como ser uma pessoa de sucesso", deixando de lado toda eventualidade ou percalços no caminho da vida. Produtos que prometem prolongar a juventude e a beleza, ideais da aparência das sociedades atuais, como forma de livrar o ser humano do fim, do envelhecimento, da condição transitória de seu próprio corpo.

Neste sentido, Pitty (2014b) diz que é “tão mais fácil se entorpecer/oscilando no eterno vir-a-ser/resistindo a me dissolver". Já que o sujeito se depara com o real do tempo, com o tempo paradoxal e se vê na impossibilidade de sustentar a fermata nas suas relações, a saída é se entorpecer, como tentativa, então, de vivenciar outros tempos para que, assim, não se dissolva na sua própria história.

Pitty nos apresenta um sujeito com medo do passar do tempo, de tão inserido no real do tempo que está. Sujeito que anseia pela proteção total contra os perigos do fim, que não suporta 
quaisquer eventualidades ou caminhos que não fazem parte do roteiro. Viver o agora como se não houvesse amanhã é um modo de controle do futuro imediato que pode ser devorador? Viver o anti-idade, o antitempo, é um modo de tentar prolongar o fim?

Por um lado, o sujeito sangra, quando há uma tentativa de controlar o tempo, fazendose necessário um prolongamento falso das notas da vida com o uso de paliativos, que não evitam o fim, mas que criam a ilusão de que ele fica cada vez mais longe. É preciso se entorpecer, é preciso tomar os remédios para amargura, é preciso ouvir frases de conforto, ou ainda, buscar por soluções antienvelhecimento. Por outro, ele suspende, faz-se necessária uma pausa legítima, um durar, momento em que não se precisa controlar, apenas sustentar o estar no tempo, pois, mesmo sendo um tempo que escapa ao sujeito, produz sua história.

\section{2. "O coelho dizendo 'já é tarde’ intensifica a ansiedade"}

"Todos os dias antes de dormir/Lembro e esqueço como foi o dia/Sempre em frente/Não temos tempo a perder" - Renato Russo.

No tempo marcado pelo eterno presente, o sujeito se reduz a um imediatismo, como se o futuro se construísse por si só através de repetidas cenas do presente, "por isso eu me entrego a um imediatismo cego/Pronta pro mundo acabar/ Você acredita no depois? Prefiro o agora" (Pitty \& Martin, 2011). O agora se reduz a um momento em que temos a capacidade de dar o próximo passo, um agora pensando no depois, nos lucros finais (Barcelos, 2009), "em incríveis e intermináveis noites/da mais besta e vã alegria" (Pitty \& Martin, 2014a).

O presente se torna, então, uma vã alegria, sem conteúdo, sem espessura, vazia de qualquer sentido, um imediatismo cego. $\mathrm{O}$ agora nada mais é que a possibilidade de correr mais além, de pegar impulso para saltar mais longe. Por isso apenas os começos são encantadores, os meios são desnecessários, a duração do momento é irrelevante. É preciso chegar logo adiante 
e além, experimentando "sempre essa boca aberta, tragando tudo pelo caminho" (Pitty \& Martin, 2014a), uma vez que se precisa consumir - mas não digerir - tudo a que se tem direito. Vivemos uma vida cheia de começos, sem meios, uma existência marcada pelo ato reduzido ao ato, sem consistência ou motivações para ser. Porém, como o sujeito consegue chegar ao fim sem meios? Como consegue deixar ir sem ter tido a oportunidade de se deixar estar?

Desta forma, as cenas do presente se reduzem a momentos efêmeros, isolados de todo e qualquer significado para o sujeito, que, como nos lembra Birman (2012), realiza, age, e logo quer passar para o próximo ato, como uma busca incansável daquilo que possa levar a um caminho válido de construção de sua existência. Quando Pitty diz "Eu só quero o começo/Me entedia lidar com o meio" (Pitty et al., 2009a), ou ainda "de tudo o que se aproveita/de tudo, só quero o agora" (Pitty \& Martin, 2014a), está, desse modo, apenas repetindo facetas de uma mesma cena, e recriando o que ela tanto quer libertar: a clausura do tempo.

Se o presente é um caminho de chegada no futuro, aniquilado pela força do agora, este, por sua vez, é um emaranhado de possibilidades que não se sabe o que pode ser. O sujeito se vê perdido em meio a tantos caminhos possíveis de construção de si, caminhos que não levam a lugar algum. São "tantas placas e tantos sinais/Já não sei por onde caminhar” (Pitty, 2003d). É neste cenário de indecisões, caminhos deslocados de sentido, que o sujeito toma para si a necessidade incansável de dar sentido à sua existência, ou ainda, uma urgência em estar e se sentir vivo, com "Tantas pessoas querendo sentir/Sangue correndo na veia/É bom sim, se movimenta e está vivo/Ouvi milhões de vozes gritando...” (Pitty, 2003e).

Se o presente se resume ao impulso para o futuro e este a uma cadeia infinita de possibilidades irreconhecíveis, vivemos no tempo das grandes promessas, provindas de lugares diversos, das propagandas, dos ideais da moda, do padrão de vida dos artistas famosos, dos corpos perfeitos. O sujeito imerso em tantas juras de milagres se vê perdido em inúmeras formas de satisfação, de ligação aos objetos de desejo, se vê fora das redes de acontecimentos 
que movem o mundo das notícias, dos eventos, e se encontra numa posição de tédio. É a sensação de que a vida passa com mais graça em um lugar onde ele não está, como nos lembra Dunker (2008), um tempo em que "se o tempo hoje vai depressa/Não tá em minhas mãos" (Pitty, 2003d).

Desta forma, o sujeito chega a um ponto em que “Até se eu ficar só na vontade, já não dói [...] Nem mesmo o tédio me surpreende mais" (Pitty \& Peu Sousa, 2005). E nesse momento, somos levados a nos perguntar sobre qual a sustentação do ato, aquele irrisório que pode tirar a pessoa dessa posição de marasmo, de tédio, de falta de ação, em que ficar só na vontade não dói, em que "Cada minuto me interessa/Me resolvendo ou não" (Pitty, 2003d). Se o sujeito entende que, por mais que se movimente, não alcançará o ideal prometido, para que se movimentar?

Esse sujeito, que parece morto, paralisado, enfastiado, que mesmo com a boca aberta, tragando tudo pelo caminho, sente falta de apetite, necessita voltar a se sentir vivo, voltar a estar presente onde os grandes eventos estão acontecendo, mesmo que não exista um grande evento. Só assim pode novamente sentir o sangue na veia, sem precisar se cortar para ter certeza de que o sangue está lá. O sangrar que diz de vida, e não de morte ou de dor. Por isso é bom sim sentir o sangue correndo na veia, sentir que se movimenta e está vivo. Para lavar o sujeito deste mal-estar, “[...] eu sinto que eu to viva/A cada banho de chuva/Que chega molhando meu corpo" (Pitty \& Peu Sousa, 2005).

Neste ponto percebemos que quanto mais a realidade social foi se afastando e se desvencilhando de suas relações com a natureza, a fim de fazer caminhar o processo civilizatório por meio do desenvolvimento tecnológico e da rede de complexidade dos grupos, mais o sujeito foi se tornando disciplinarizado ao tempo (Elias, 1998). Sobretudo a partir da Modernidade, o tempo ganha um caráter racionalizado e objetificado, com o avanço de técnicas de medição, como a proliferação dos relógios (Kehl, 2009; Salum, 2009). Com isso, o tempo 
que antes apenas marcava as atividades sociais, passa a se esvaziar e se tornar artificial, ditando o ritmo da própria existência (Giddens, 1991).

Assim, o tempo regulador da vida humana abre espaço para a objetificação das relações, afastando, cada vez mais, o homem da natureza, em nome do avanço tecnológico. Os produtos e técnicas ganham um caráter subjetivo, ao passo que o sujeito, vai se tornando, aos poucos, uma coisa, um objeto que opera a subjetivação do tempo (Morin, 1969/2005). O que podemos perceber na sociedade atual é a emergência ou necessidade de um movimento contrário: o reencontro com a natureza, com um banho de chuva que nos faça vivos.

Quanto mais o ser humano se viu afastado dela, mais perdido ficou. Se antes a natureza ditava os ritmos, no decorrer da história humana ela foi se tornando um objeto de estudo e uma ferramenta a favor do sujeito, sujeito este que não sabe, muito bem, como lidar com tamanha ruptura. Estão na moda os produtos orgânicos, a alimentação detox, que desintoxica o ser humano de suas próprias criações, como forma de dizer que é preciso voltar à natureza para levar uma vida saudável.

Estão na moda também os retiros espirituais que prometem uma harmonização entre sujeito e meio ambiente, a partir da troca de energias com a natureza. Sem falar dos produtos biodegradáveis, das leis ambientais, da promoção cada vez mais elevada da reciclagem como forma de proteger a natureza. O ser humano tem percebido, talvez como nunca, que a ruptura abrupta de sua relação com o meio ambiente, do qual faz parte enquanto organismo, tem adoecido a subjetividade que não sabe lidar fora de sua morada primária: a natureza. Porém como se dar tempo de se resgatar enquanto sujeito natural numa sociedade cada vez mais eletrizante, eletrizada, automática, conectada com o virtual, deslocada do orgânico?

O sujeito, em busca de participar da vida prometida da atualidade, acelera seu ritmo de busca por sentidos de existência, mesmo que estes se tornem, cada vez mais, inalcançáveis, por isso "Tenho pressa, eu vou correr/Sempre há muito o que fazer/[...] Sempre correndo mais e 
mais e mais e mais e mais..." (Pitty, Duda, Joe \& Martin, 2009b). É com este sentimento de que sempre há muito o que fazer, com a sensação de que há, como define Dunker (2008), um evento acontecendo em algum lugar do qual o sujeito está atrasado ou excluído, que o mesmo busca se ligar aos objetos sempre apresentados, tragar tudo pelo caminho, pelas inúmeras redes de informação, mas que nunca chegam de fato até ele.

Pitty et al. (2009b) confessa: "Vê? É simples/Eu nem me importo mais/Sempre seguindo/Pra nunca chegar/O coelho dizendo “já é tarde'/Intensifica a ansiedade”. Essa pressa e "ansiedade", bem como a apatia de não se importar mais, são formas sintomáticas, que denunciam a relação doentia com o tempo nas sociedades ocidentais atuais. São formas de o sujeito buscar ainda uma possibilidade de existência que signifique o aproveitamento de sua vida. São meios da possibilidade de não a encarar de uma forma vazia, longe dos palcos, bem como de não sentir, para não ter que experimentar o que falta e sempre vai faltar.

Por isso, vemos um sujeito que luta, o tempo todo, para significar a existência e se manter protegido de suas fragilidades, assim, "vivo/tentando/domar/meu mundo/nunca/consigo/saber/sigo/tentando/sair/do fundo/nado,/não quero/morrer” (Pitty, 2014b). O estilo e a forma desta composição nos mostram um sujeito sôfrego, sem fôlego, cansado, que tenta respirar a cada palavra, ou passo que dá, em busca de sua urgência em viver e de não morrer, mesmo que em sentido simbólico.

Esta forma de vida nos remete às palavras de Kehl (2009) e Cantarelli (2013) ao dizer do sujeito em estado de alerta e prontidão máximas, e também ao que Santos Neto (2013) diz da necessidade capitalista de redução e economia do tempo. Percebemos um sujeito que confessa que "amanhã, acordo e resmungo:/'eu quero minha vida de volta"” (Pitty \& Martin, 2014a), que percebe que esta pressa em agir e viver, a boca aberta que quer aproveitar tudo, acabam, pelo contrário, negando a própria vida, enquanto se corre para encontrá-la. 


\section{3. "E o tempo é só meu e ninguém registra a cena"}

"Just got to carry what you can. Have the heart of a giant, but know you're a man" - Roo Panes ${ }^{13}$

Pitty nos apresenta a desaceleração dos ritmos como uma forma de não se sufocar com a pressão do passar do tempo, como uma forma de resistir ao imperativo do aproveitamento máximo, da aceleração para se alcançar tudo o que se deve buscar para dar sentido à vida. E ela parece querer dizer que é preciso ter tempo para se dar um tempo. Isso aparece na forma de canções consideradas, de certa maneira, mais calmas e lentas, quando ela fala de dor, do amor e do encontro legítimo consigo e com o outro. São modos de mostrar que, sem a preocupação, ou o que ela chama de "ansiedade", sobre o transcorrer do tempo, o sujeito pode sofrer menos com a angústia da falta de controle sobre o passar de sua vida. É uma forma de se reconciliar, fazer as pazes com o real do tempo paradoxal.

Desacelerar, como nos adverte Barcelos (2009), não tem necessariamente a ver com tentar fazer o tempo ir mais devagar, para retardar o encontro com o fim, e nem as formas de desaceleração que também estão na moda nas sociedades ocidentais - assim como as de aceleração - como o refúgio na natureza ou a busca por tratamentos e spas que prometem "relaxar" o sujeito, diminuindo o seu ritmo intenso. O que Pitty propõe é uma desaceleração da ordem do embate, o encontro com o outro, o olho no olho, tão perdido nas relações contemporâneas. Ela nos convida e nos chama para sentar, conversar, encontrar e conhecer a si mesmo e ao outro, sem esperar algo mais, algo além, uma promessa de futuro com este tempo gasto que não é experimentado como perdido e que precisa ser resgatado: "Ei, não vá ainda

\footnotetext{
13 "Só tem que levar o que você puder. Tenha o coração de um gigante, mas saiba que você é um ser humano" (tradução nossa).
} 
embora/Beba mais um copo/É que logo agora vai começar a história/Se sente na pele que chegou a hora/Saber a qual é olhando no olho" (Pitty, 2005a).

Esse olhar no olho permite a troca, permite o encontro sutil de si com o outro, que faz com que o presente seja carregado de sentido, com espessura (Barcelos, 2009), como se estivesse passando mais devagar: "E enquanto você conversa e me beija/Ao mesmo tempo eu vejo/As suas cores no seu olho, tão de perto/Me balanço devagar, como quando você me embala/O ritmo rola fácil/ [...] e porque, quando você me abraça, o mundo gira devagar/E o tempo é só meu e ninguém registra a cena/De repente vira um filme, todo em câmera lenta" (Pitty \& Peu Sousa, 2003).

Não é preciso mais registrar a cena, experimentar a sensação de que o hoje deve ser feito pensando no amanhã, ou de que há um algo além esperando para ser consumido. É preciso, simplesmente, sentir o encontro e, então, "De repente a gente nessa dança muito doida/rolando, suando, nunca para de pulsar/lá se vão as horas, ninguém conta mais o tempo" (Pitty \& Martin, 2014c). Se o tempo também carrega a dimensão do encontro significativo com o outro, é possível viver no tempo em que o tempo não precisa ser contado ou resgatado.

Contudo, pode parecer que a desaceleração proposta pelo encontro com o outro se dá apenas nas formas das alegrias e do amor, tão incentivadas pelo ideal da felicidade incondicional, da sociedade contemporânea, que, como lembra Barcelos (2006), não aconselha encontros ruins. Porém, Pitty mostra que o reconhecimento da dor e da perda também pode ser um modo de encarar a importância do outro e do presente carregado de sentido, ainda que este tempo passe e não volte mais: "Sabe, serei seu lar se quiser/Sem pressa, do jeito que tem que ser/Que mais posso fazer? - Só te olhar dormir/Agora, só agora/Correndo pelo campo/Antes de deixá-lo ir/Muda a estação/Necessário e são/Você a florescer/Calmamente, lindamente" (Pitty, 2009b). 
Cantar a perda, cantar a saudade, a despedida, no tempo necessário para mudar a estação, também é uma forma de reconhecer os intervalos significativos, caso contrário, essa dor teria de ser evitada e este tempo perdido deveria ser buscado de volta. Assim, ela também canta contra a corrente, contra os ideais da felicidade plena, do tempo gasto em vão com a dor, por isso "Você pode não entender se às vezes fico pelos cantos/Um tanto quieta, recolhida, mergulhada no meu pranto/É que ele me liberta na hora/No momento em que eu boto pra fora/O que já não me serve vai embora/E assim, eu fico leve” (Pitty, 2009a).

É preciso tempo para sentir, é preciso tempo para se encontrar, para encontrar o outro, para afetar e se deixar ser afetado, para reconhecer o que é bom e o que não é, para conversar com a tristeza e com a perda, para que, com isso, se fique leve. Pitty nos mostra que, de certa forma, a aceitação do lado obscuro do ser humano e do fim do transcorrer do tempo, e da própria existência, são uma saída para o reconhecimento de que, ao mesmo tempo em que a desordem, a dor, a perda e a morte geram angústia, podem ser também motivos para afirmar a vida.

Uma vida onde "A minha alma nem me lembro mais/Em que esquina se perdeu/Ou em que mundo se enfiou/Mas já faz algum tempo/[Mas eu não tenho pressa]" (Pitty \& Peu Sousa, 2005). Dessa forma, ela reconhece o real do tempo paradoxal, ela se reescreve na sua história enquanto pode, enquanto lhe é permitido, sem entrar em um processo de angústia com o tempo que lhe escapa.

Sendo assim, é pela resistência que Pitty afirma a vida, pelo lugar possível em meio a tantas formas automáticas, denunciadas por Kehl (2009), de sentir, de pensar e de existir. Ela reconhece a importância do parar no tempo, do experimentar os intervalos a fim de saber o que lhe importa ou não.

Com isso, vivendo um tempo significativo, aberto aos encontros, o sujeito sente que pode seguir em frente, mesmo que, de tempos em tempos, precise de um novo tempo para se 
resolver, para se encontrar e, sendo assim, "Enquanto eu tiver chão sobre os pés/Enquanto eu puder caminhar/Enquanto eu puder estar viva/Enquanto minha hora não chegar/Talvez eu não vença o tempo todo/E ainda posso até cair/Só quero manter minha alma forte/Erguer a cabeça e seguir" (Pitty, 2005b).

\section{4. "Por baixo ainda é serpente e devora a cauda pra recomeçar"}

"Ando devagar/Porque já tive pressa/E levo esse sorriso/Porque já chorei demais" - Almir Sater e Renato Teixeira.

No embate entre as ordens vigentes do tempo - que ora aceleram os ritmos, ora vendem ideais de desaceleração - e a necessidade de o sujeito tomar um tempo para pensar sobre a própria existência e sobre o encontro com si e com o outro, é que se percebe que "É toda torta a sensação/de que o caminho é/se encontrar na perdição/ [...] e se a sorte aparecer, deixa ela entrar/ me coloco à sua mercê, e deixo ela entrar/pela fresta que se abriu: deixa ela entrar!/antes hoje do que nunca mais" (Pitty \& Martin, 2014b). É pela fresta, pelo lugar possível entre a luta com as formas de vida exigidas na sociedade, em sua relação sintomática com o tempo, que o sujeito pode deixar a sorte entrar. Pode aceitar que nem sempre os tempos são tempos de bons presságios, que existem os tempos de revés e que nem sempre "a sorte vai bater à porta", mas que, quando isso acontecer, ele precisa experimentar, mesmo que não dure para sempre.

É neste sentido que Barcelos (2009) sugere que é pela fresta que surgem algumas formas de viver a resistência ao tempo dominante que exige estabilidade. É preciso resistir aos ideais que prometem "finais felizes" e "fórmulas mágicas". Ela defende que a abertura ao acaso é “essencial nos processos de criação", processos estes que ocorrem, sobretudo, na relação com o tempo. Este acaso possibilita o surgimento de novas formas de se experimentar a vida. Se encontrar na perdição, como pede Pitty, é uma forma de reconhecer e se reconciliar com o real 
do tempo, é a possibilidade de acolher o que é estranho e criar o que Barcelos (2009) chama de condições de produção de diferença.

Neste sentido, deixar a sorte entrar pela fresta que às vezes se abre é uma tentativa de criar uma condição distinta do eterno presente, que, como define Mészáros (2007), se sustenta na descrença histórica de que este tempo é a única forma de se viver, de que não há mais jeito de se fazer um tempo diferente. Se abrir para a perdição não tem a ver com "deixar a vida me levar" ou com o que Birman (2012) chama de ação difusa, ou seja, de permanecer neste estado de eterno acaso. Pitty nos adverte que "o acaso/empurra quem/se agarra à borda, preso em negação" (Pitty, 2014c), como forma de dizer que o acaso é importante para criar novas formas de vida, mas que não devemos viver num eterno estado de descrença e de negação de que podemos, apesar de tudo, viver novas formas de tempo e sujeito.

O que parece importar é a dimensão psicológica e o resgate do sujeito, como propõem Freud (1930[1929]/1996f) e Mészáros (2007), que tem se visto objetificado, perdido em tantos caminhos, em tantas angústias. Um sujeito que sente uma "Pane no sistema, alguém me desconfigurou/Aonde estão meus olhos de robô?" (Pitty, 2003a), que não sabe mais viver de uma forma orgânica, de uma forma natural, sem que o tempo e as ações sejam, o tempo todo, pensados, maquinados. Pitty denuncia, então, o discurso da ciência moderna e da tecnologia que, em nome do progresso, apagam a verdade do sujeito, que confessa que sente "Parafuso e fluido em lugar de articulação/Até achava que aqui batia um coração/Nada é orgânico, é tudo programado/E eu achando que tinha me libertado/Mas lá vêm eles novamente e eu sei o que vão fazer:/Reinstalar o sistema" (Pitty, 2003a).

Quando este sujeito reificado se indaga "Pra que dissimular?/Se ela me segue aonde quer que eu vá/Melhor encarar/E aprender com ela a caminhar/Não vou mais negar/Por todo caminho minha sombra está/Eu quero saber me querer/Com toda beleza e abominação/Que há em mim" (Pitty \& Martin, 2009), ele busca ter tempo de produzir encontros saudáveis com a 
perdição e não mais com o automatismo. Para o sujeito, o conselho de Pitty é que talvez seja melhor encarar, parar de negar, saber se querer, para que se possa se reconhecer enquanto ser. Portanto, parece ser necessário olhar de frente a beleza e a abominação que nos habitam, que nos fazem humanos, parar de negar a dor, o obscuro, a vulnerabilidade, o real do tempo irreversível, mesmo que este seja um processo doloroso.

É necessário se encontrar, se deparar, com o real do tempo, que ora nos relembra do passar do tempo, ora nos retira dele, que sempre nos escapa. Um real do tempo que ora faz história, ora nos faz sentir como se não vivêssemos na história. É preciso reconhecer esse real, para que possamos, de fato, nos recolocar enquanto sujeito da nossa existência e saber que o tempo realmente nos chega e nos escapa.

Sobre este processo doloroso de reconhecer a beleza e a abominação, o tempo paradoxal, ou seja, de se encarar as novas possibilidades de vida através da fresta e da perdição, em uma sociedade que dá cada vez menos espaço para sua concretização, o sujeito "nem pensava que/essa hora ia chegar/saber não insistir/nessa história de se gastar" (Pitty, Duda, Martin \& Guilherme, 2014). Pitty quer dizer de um encontro brusco com uma hora que chega sem avisar, com um corpo que já não aguenta mais o ritmo da vida, que se gasta o tempo todo. É uma forma de se desvencilhar do discurso de que "de tudo o que se aproveita/de tudo só quero o agora".

Não é à toa ouvirmos os discursos de sujeitos estafados e fadigados com o modo que levam suas vidas, um modo que atropela o próprio limite do corpo, que adoece e sintomatiza, como forma de pedir socorro, de pedir uma fermata, pois recusa, o tempo todo, o real do tempo. Pitty, então, nos alerta que é preciso ter coragem para lidar com "o traquejo de esperar/a hora certa de esbravejar" (Pitty et al., 2014), é preciso saber enfrentar as intempéries e saber que nem sempre se pode ir mais além do que se consegue, é preciso viver o paradoxo e parar de tentar resistir a se dissolver. Assim, ela nos aconselha a "depois do rancor, respirar/vigiar ao 
redor, e respirar/aprender a usar o olho calmo" (Pitty et al., 2014), um olho que precisa de tempo para ver que certas coisas fogem ao controle e que, em alguns momentos, precisa se perder de vista.

Assim, Pitty define esse tempo do encontro abrupto com a fresta, com a possibilidade de transformação, de ser outras formas de vida, como um "cão que já nem ladra mais, só morde" (Pitty et al., 2014). Este é um tempo de muda, como fala Mezan (1998), um tempo em que o sujeito precisa se renovar, onde, Pitty reconhece que "já não sabia mais de nada/é besta assim esse quase-morrer/desconcertante perceber/que as coisas são, e tudo floresce a despeito de nós" (Pitty, 2014d).

É nesse quase-morrer que se encontra um sujeito exigido, o tempo todo, a agir, a fazer, a correr atrás do que ainda não há, como relembram Brunetto (2008) e Gallano (2008). Além disso, o quase-morrer diz das coisas que nos fogem à captura, de coisas que florescem a despeito de nós, da abominação e da perdição que se fazem presente, mesmo que não vivamos em um tempo propício a aceitá-las de frente.

Sendo assim, viver pela fresta é dar um basta, é dizer que "chega dessa pele/é hora de trocar/por baixo ainda é serpente/e devora a cauda pra recomeçar” (Pitty, 2014c). É afirmar um devir que possibilita novas formas de vida para um corpo e um sujeito que já não podem mais ser quem são, por meio de uma relação doentia com as formas vigentes do tempo. Tempo este, que, de acordo com Lombardi (2008) não nos dá muitas chances de manejo, mas que, por carregar nosso desejo, se faz enquanto possibilidade de renovação. Aceitar a inconstância, algo tão exigido e, ao mesmo tempo, renegado nos tempos atuais, é aceitar o encontro com si mesmo, com o outro, e com o real do tempo cheio de sentido de re-criação.

É aceitar um tempo de, como nos relembra Chatelard (2008), a-parição do ser, um tempo que demora para o sujeito se fazer. Um tempo que "pelo fogo:/transmutação/sem afago, lapidando o aprendiz/o que sobra é cicatriz" (Pitty, 2014c). É cicatriz de uma história que se 
faz a cada intervalo de significado vivido e verdadeiramente experimentado, que deixa marcas e inscrições no corpo e na subjetividade.

Sendo assim, Pitty ainda luta com esperança e mostra um último fôlego para afirmar que espera um tempo em que não precisa se defender e resistir a se dissolver, ou um tempo em que não precisa correr sempre mais atrás de algo que não chega, com pressa e apatia. Espera um tempo em que não seja preciso registrar a cena. É um tempo em que "a sustentação é que a manhã já vem/logo mais amanhã já vem” (Pitty, 2014c). A manhã não como o evento natural após a noite ou o amanhã como o dia depois de hoje, mas, sobretudo, como um tempo que não se resuma a atos irrisórios, um tempo novo e de novidade. Um tempo de resistência, um tempo de fresta, de criação de um tempo que se sustenta e que dura, sendo intervalo significativo para o sujeito. Um tempo que propicia a reinscrição da subjetividade em sua própria história. 


\section{“POR FIM, OS FUNERAIS": CONSIDERAÇÕES FINAIS}

Uma ideia básica se faz necessária para discutir sobre o tempo: não se trata apenas de uma instância da natureza e nem de uma criação originalmente humana. Reduzir o tempo a simples objeto é cair no risco de criar e reproduzir uma cisão de mundo e tratá-lo como um produto artificial do desenvolvimento científico que se deu a partir da Modernidade. Sendo o tempo uma categoria que não deve ser reduzida a objeto, ele desafia o conhecimento no sentido de construir possibilidades de superar a divisão ocasionada pelo modelo científico moderno, que, aos poucos, cindiu ser humano e natureza.

Uma das razões que motivaram o movimento científico moderno se deve ao fato de o ser humano reconhecer que o pano de fundo de sua existência é um devir, uma série de transformações constantes que gera angústia, devido a sua precariedade e ao medo da morte. Se antes era possível superar essa fragilidade da vida e o medo de seu fim através da aceitação da finitude ou da crença na eternidade, com o desenvolvimento das relações nas sociedades modernas os homens tentavam se precaver voltando-se para a criação racional de leis naturais eternas e imutáveis.

Contudo, para os sujeitos da atualidade, as leis eternas e imutáveis já não têm se sustentado tanto, o tempo chega simples como um temporal: vem sem avisar, sem se fazer percebido, mas chega e pega este sujeito, o aniquila, deixa as impressões na sua pele e na sua história. A dimensão trágica da vida da antiguidade, o aspecto de encarar o tempo e a morte de frente, foi perdendo seu espaço, ora por uma centralização da razão, herança da vida moderna, uma vida que não permite o confronto direto com o caos, ora por uma espécie de encontro inevitável com o desconhecido, seguido da incapacidade de se lidar com o mesmo e da necessidade de não se dissolver. 
A percepção do tempo se faz presente devido a uma série de transformações no decorrer da história da humanidade, transformações que propiciaram a disciplinarização do tempo por conta do desenvolvimento e aumento da complexidade social. A vida humana foi se inserindo como determinação temporal ao mesmo passo que o próprio tempo foi se amarrando à regulação social dos grupos e sujeitos, no sentido de, em primeiro lugar, organizar os processos produtivos e, em segundo, reger a existência individual. O tempo assusta porque virou a própria vida humana e o seu passar significa o desenrolar da história do sujeito e da humanidade, visto que a primeira é bem menor em comparação à segunda, o que é motivo de frustração, já que a necessidade de preencher esta vida - tão curta - de sentido se tornou a máxima do desejo atual.

Os medos que poderíamos deixar para trás ao pedir o controle do tempo é o próprio medo sentido pelo decorrer deste, que aproxima ao medo do fim. As armas seriam as formas de fuga do tempo, as drogas, lícitas e ilícitas, sejam aquelas traficadas ou as comercializadas em qualquer farmácia, drogas psicológicas também, que confortam o sujeito. Temos, em outros casos, drogas anti-idade que viciam na tentativa de buscar uma imortalidade através da juventude eterna. Obviamente, estas drogas fracassam em suas propostas imediatistas, por isso estamos sempre acompanhados pelos medos e armas.

Talvez tenhamos nos ousado demais em pensar que a natureza era passível de racionalização. Talvez tenhamos encontrado com um real do tempo do qual não estávamos preparados para reconhecer. Isso, talvez, se explique pelo desejo, cada vez maior na atualidade, do nosso retorno à natureza. Se sente na pele um corpo que pede um tempo, uma suspensão. Um corpo que está estafado pelo esgotamento de seus limites, que vem gritando por socorro e pedindo, com mais intensidade, a sua organicidade de volta.

O tempo exige tanto da nossa vida porque é a própria vida. Estamos totalmente submissos a suas amarras, por conta de processos históricos, sociais e existenciais. Justamente por estar atrelado à própria existência, e pela falta de eficácia dos métodos de controle ou armas 
para batalhar contra o tempo, precisamos nos virar como podemos, de acordo com as modalidades de pulsão que nos são apresentadas pela vida em cultura.

A transformação das modalidades pulsionais nos mostram, também, as divergências nas relações com um tempo cada vez mais regulador. O declínio do pensar moderno e o elogio ao ato contemporâneo revelam e denunciam uma nova relação com o tempo. Neste ponto, relembramos dos sujeitos apresentados na introdução deste texto: alunos no último ano do ensino médio que desejavam "fazer a vida" através do mundo do trabalho, ingressando no curso técnico ou superior; ou ainda, ex-usuários de drogas em um tratamento que demanda um intervalo de meses, sofrendo a angústia de estar perdendo tempo e não estar "fazendo a vida", que passa fora dos muros da instituição. Agir é preciso, agir é fazer a vida e, se a vida é o próprio tempo, fazer a vida é manejar o tempo.

Porém, o ato contemporâneo é o ato difuso que não leva a nada. Então por que agir? Para sair do marasmo do eterno agora, do estado de tédio, da ação efêmera sem espessura, sem densidade, sem conteúdo, que não escreve história porque aniquila a sustentação com o passado e, mesmo esperando a realização pessoal futura, nunca se alcança esse futuro, pois o agora é destituído de vida e é apenas um passo em falso esperando que algo aconteça depois. Age-se para tentar fazer história, para recuperar não o tempo que ainda se tem, porque não se sabe que tempo se tem, mas o tempo perdido. Só se sabe do tempo que passou entre a necessidade de viver e a satisfação, portanto, é preciso agir para resgatar esse tempo perdido, para ter uma vida de volta na história. Para se escrever através da ligação com os objetos que prometem uma possibilidade de reinserção do sujeito em sua própria vida.

Escrever o que? Escrever-se contra o que? Contra o tempo do eterno presente. Do real do tempo, do tempo paradoxal: o tempo que não é agora mas pode ser qualquer momento. $\mathrm{O}$ tempo que é história, mas que o sujeito não se faz reconhecido nessa história. O tempo de um grande evento que está acontecendo, mas que não acontece em lugar algum. É para este evento 
que se quer ir, para um lugar onde estejam criando história, mal sabendo que a história já se faz no cotidiano.

O ser humano sempre enfrentou, durante a sua história, encontros com os inevitáveis, com o desconhecido, com o novo que gera confusão. Na Modernidade foi o declínio do Feudalismo e da crença no divino, onde o homem se viu sem bases seguras para constituir a própria vida e teve que se virar, fazer algo com isso. Na contemporaneidade, um dos encontros com o novo, com o desconhecido, que revela o caráter caótico do sujeito, é a forma sintomática de lidar com o tempo, esse tempo que passa, que constitui história e sujeito, mas que ao mesmo tempo não passa, reafirmando o desejo que sempre acompanha o sujeito. É o encontro com o real do tempo, com o tempo paradoxal que ora exige ação, ora exige desaceleração, ambas destituídas de sentido porque não se alcança a história que se quer fazer.

É nesse modelo de encontro que Pitty se insere, enquanto sujeito desta realidade desencontrada, caótica. Este é o atrativo que Pitty nos traz através de sua música: a possibilidade de falar de um sujeito que vive o desconhecido, e dizer que desconhecido é esse: a relação caótica com o real do tempo paradoxal. Pitty é caótica e fala do sujeito caótico. Ela fala e também é um sujeito que tenta usar medos e armas contra o tempo, um sujeito que vive em guerra com o tempo, um tempo que não se abraça, pois é inimigo. Ela é e fala sobre um sujeito do tempo paradoxal que vive esperando o agora, mas não vive o agora, ou, se o vive, o faz de forma insossa.

Ela reproduz a cena dos modelos vigentes das nossas relações sintomáticas com o tempo que exigem pressa e urgência ou, num oposto, de mesmo fundo, um marasmo e uma apatia. $\mathrm{E}$ também desconstrói porque percebe que essa relação já não lhe está cabendo. Já está se sentindo perdida nessa realidade, é preciso fazer algo, é preciso se reinventar, porque assim não dá mais, é preciso parar de resistir a se dissolver. 
É preciso, então, experimentar o encontro, o presente com densidade e duração, o presente da fermata, que suspende o tempo que não exige mais controle, pretensões, medos e armas e que, consequentemente, não gera angústia de algo que não se sabe o que, porque é um tempo que já não escapa. Suspende o tempo para o sujeito fazer história, para se fazer, para constituir sua própria existência e se colocar nela, para parir o sujeito. $\mathrm{O}$ encontro com si e com o outro, o encontro legítimo, que não espera de algo para depois disso, mas que vive enquanto se constitui, enquanto se faz, enquanto se vive. Um tempo onde o sujeito precisa se perder para se encontrar e reencontrar, para se fazer e refazer, para viver e reviver, resgatando-se na vida.

É importante dizer que nem todos nós temos este privilégio, numa sociedade comandada pelas relações e ritmos do modo de produção capitalista, não há muito espaço para se refazer, para se recolocar na história enquanto sujeito de sua vida. O que fazer então? O que fazer para aproveitar o encontro? Para viver a vida que se constitui na duração da fermata, da suspensão? Cabe a nós encontrar um lugar, uma resistência, uma fresta, fresta essa que deve ser rearranjada na nossa relação com a cultura, produzindo novas formas de se lidar com o tempo. É na vida em cultura, na vida que se constitui historicamente, que podemos resistir e viver na fresta, na sutilidade dos encontros que podem nos permitir viver outros tempos, que não aqueles pessimistas, do eterno presente, onde não se há o que fazer.

Ao falar do tempo através das discussões da História, da Sociologia e da Psicanálise, utilizando-se da Arte, em específico as músicas de Pitty, para atravessar um caminho possível de apresentar a vulnerabilidade humana e este encontro com o real do tempo, pudemos dizer de um tempo que, ao mesmo tempo, é natural, que se configura enquanto passar e desenrolar, e outro que se faz subjetividade, na relação viva com o sujeito. Tempo é natural e subjetivo, relação impossível de separação, porque ser humano é também natureza.

Sendo assim, se fez possível reconhecer uma relação que inscreve o tempo, o sujeito e sua relação com os processos históricos, sociais e culturais, reconhecendo sua condição caótica, 
que se faz por um tempo do paradoxo que passa e escapa, que constitui e aniquila. A partir da aproximação com Pitty, pudemos entender um pouco melhor os processos de subjetivação enquanto tempo, deixando-se evidenciar os sintomas e configurações de nosso temposubjetividade.

Talvez não saibamos responder que dia agitado hoje seria, se não fosse o amanhã, e não saibamos, também, dizer, afinal, o que é o tempo. O tempo é subjetividade, é paradoxo, é constituição de história de um sujeito que, cada vez mais, tem se visto fora de sua própria história. Mas o tempo também é algo da ordem do inexprimível, do inominável, do não representável, porque marca um encontro real com a figura da morte, com o fim inexorável. O encontro com o real do tempo, impossível de salvação, porque passa e escapa ao sujeito, não é representável, e, ao mesmo tempo, se faz como mal-estar, pois vivemos em uma sociedade que, carregando os traços da Modernidade, não tolera o real, o encontro com aquilo que não se pode nomear.

Encerramos este trabalho com questões em aberto, uma vez que se trata do assunto do tempo paradoxal, que não nos permite exprimir tudo em respostas. Como se encontra o sujeito que não sabe como mais viver uma vez que não se pode ter o tempo de se constituir enquanto vida? Se o agir é a tentativa de resgatar um tempo perdido entre a necessidade pulsional e a sua satisfação e, levando-se em conta, que este intervalo tem sido cada vez, podemos entender que o tempo perdido a ser recuperado também é menor? Talvez não seja por esse lado, mas sim, podemos pensar, também, que, por conta dos atos em busca da satisfação serem irrisórios, ou seja, passíveis de não satisfação, logo o intervalo entre a necessidade pulsional e a satisfação legítima tem estado cada vez maior. Sendo assim, o tempo perdido a ser resgatado é mais longo, podendo durar, senão, a própria história do sujeito, que não se vê mais satisfeito e que entende a própria vida como um grande tempo perdido. São questões que se fazem pertinente para uma futura discussão. 
Assim, citando mais uma vez Pitty, é melhor que reconheçamos que, enquanto temposubjetividade, somos um sujeito "Pálido, doente/rendido, decadente", que está aí para viver o real do tempo, que nos chega, mas também nos escapa, um tempo insuficiente para se realizar tudo o que se deseja. Mas isso não é desistir, não é negar a fresta, a fermata e a possibilidade de se fazer tempo, e de fazer, também, novos tempos. Assim, continuando nas palavras da cantora-sujeito-tempo, talvez devamos entender que "viver parece mesmo coisa de insistente". E é mesmo. 


\section{REFERÊNCIAS BIBLIOGRÁFICAS}

Agostinho, S. (1980). Confissões. (2 ed.). (J. O. Santo \& A. A. de Pina, Trad.). São Paulo: Abril Cultural. (Obra original publicada em 397-398).

Aguilera, V. (2008). Conceitos de física moderna - O espaço, o tempo e o espaço-tempo. Em: http://www.valdiraguilera.net/conceitos-fisica-moderna-4.html\#. Acesso em 24 de maio de 2014.

Aparício, S. (2008). Tempo: Lógica e sentimento. (P. M. Rona, Trad.). Em Os tempos do sujeito do inconsciente - A psicanálise no seu tempo e o tempo na psicanálise. V Encontro Internacional da IF - Escola de Psicanálise dos Fóruns do Campo Lacaniano (pp.27-28), São Paulo.

Araújo, J. N. G. de. (2004). Tempo do sujeito, tempo do mundo, tempo da clínica. Revista MalEstar e Subjetividade, 4(2), 235-250.

Askofaré, S. (2008). O inconsciente e(é) o tempo. (P. M. Rona, Trad.). Em Os tempos do sujeito do inconsciente - A psicanálise no seu tempo e o tempo na psicanálise. $\mathrm{V}$ Encontro Internacional da IF - Escola de Psicanálise dos Fóruns do Campo Lacaniano (pp.25-26), São Paulo.

Barcelos, T.M. (2006). Re-quebros da subjetividade e o poder transformador do samba. (Tese de Doutorado, Pontifícia Universidade Católica, São Paulo, Brasil).

Barcelos, T.M. (2009, Jan./Abr.). Subjetividade e samba: na roda com Paulinho da Viola. Fractal: Revista de Psicologia, 21(1), 57-68.

Bauman, Z. (2005). Vidas desperdiçadas. (C. A. Medeiros, Trad.). Rio de Janeiro: Jorge Zahar Ed.

Birman, J. (2012). O sujeito na contemporaneidade: Espaço, dor e desalento na atualidade. Rio de Janeiro: Civilização Brasileira. 
Blanc, A; Bastos, C. (1998). Resposta ao Tempo (Gravada por Nana Caymmi). Resposta ao Tempo [CD]. Rio de Janeiro: EMI.

Brunetto, A. (2008). Um tempo de espera para o obsessivo: "Está provado: quem espera nunca alcança". Em Os tempos do sujeito do inconsciente - A psicanálise no seu tempo e o tempo na psicanálise. V Encontro Internacional da IF - Escola de Psicanálise dos Fóruns do Campo Lacaniano (pp.121-123), São Paulo.

Buck, S. (Autor); Hunter, T (Diretor). (2009). Slack Tide. Em: Weiler, E. (Produtor). Dexter [Série de Televisão]. Estados Unidos: Showtime.

Cantarelli, A. C. C. (2013). Entre moda e sujeito: Trânsitos da subjetivação. (Dissertação de Mestrado, Universidade de Brasília, Brasília, Brasil).

Carvalho, M. T. P. de. (2001). Intimidade e experiência amorosa: Do campo psicoterapêutico ao campo da cultura - um ensaio de apreensão teórica. (Dissertação de Mestrado, Universidade de Brasília, Brasília, Brasil).

Castro, J. E. de. (2008). A psicanálise e o tempo. Psicanálise \& Barroco em Revista, 6(3), 6074.

Chatelard, D. S. (2008). Do tempo. Em Os tempos do sujeito do inconsciente - A psicanálise no seu tempo e o tempo na psicanálise. V Encontro Internacional da IF - Escola de Psicanálise dos Fóruns do Campo Lacaniano (pp.10-11), São Paulo.

Checchia, M. A. (2008). Tempo e política na clínica psicanalítica. Em Os tempos do sujeito do inconsciente - A psicanálise no seu tempo e o tempo na psicanálise. V Encontro Internacional da IF - Escola de Psicanálise dos Fóruns do Campo Lacaniano (pp.287-289), São Paulo.

Dunker, C. I. L. (2008). A psicanálise em seu tempo. Em Os tempos do sujeito do inconsciente - A psicanálise no seu tempo e o tempo na psicanálise. V Encontro Internacional da IF - Escola de Psicanálise dos Fóruns do Campo Lacaniano (pp.23-25), São Paulo. 
Elias, N. (1994). A Sociedade dos indivíduos. (V. Ribeiro, Trad.). Rio de Janeiro: Jorge Zahar Ed.

Elias, N. (1998). Sobre o tempo. (V. Ribeiro, Trad.). Rio de Janeiro: Jorge Zahar Ed.

Figueiredo, L. C.; Santi, P. L. (2006) Psicologia: Uma (nova) introdução. São Paulo: EDUC. Fingermann, D. (2008). Os tempos do sujeito do inconsciente. Em Os tempos do sujeito do inconsciente - A psicanálise no seu tempo e o tempo na psicanálise. V Encontro Internacional da IF - Escola de Psicanálise dos Fóruns do Campo Lacaniano (p.09), São Paulo.

Freud, S. (1996a). Formulações sobre os dois princípios do funcionamento mental. Em Freud, S. Edição standard brasileira das obras psicológicas completas de Sigmund Freud. (Vol. 12, pp.233-244). Rio de Janeiro: Imago. (Obra original publicada em 1911).

Freud, S. (1996b). O Inconsciente. Em Freud, S. Edição standard brasileira das obras psicológicas completas de Sigmund Freud. (Vol. 14, pp.165-222). Rio de Janeiro: Imago. (Obra original publicada em 1915).

Freud, S. (1996c). Além do princípio de prazer. Em Freud, S. Edição standard brasileira das obras psicológicas completas de Sigmund Freud. (Vol. 18, pp.13-75). Rio de Janeiro: Imago. (Obra original publicada em 1920).

Freud, S. (1996d). A negativa. Em Freud, S. Edição standard brasileira das obras psicológicas completas de Sigmund Freud. (Vol. 19, pp.263-269). Rio de Janeiro: Imago. (Obra original publicada em 1925).

Freud, S. (1996e). O futuro de uma ilusão. Em Freud, S. Edição standard brasileira das obras psicológicas completas de Sigmund Freud. (Vol. 21, pp.13-63). Rio de Janeiro: Imago. (Obra original publicada em 1927).

Freud, S. (1996f). O mal-estar na civilização. Em Freud, S. Edição standard brasileira das obras psicológicas completas de Sigmund Freud. (Vol. 21, pp.67-148). Rio de Janeiro: Imago. (Obra original publicada em 1930[1929]). 
Freud, S. (1996g). Novas conferências introdutórias sobre psicanálise - Conferência XXXI: A dissecação da personalidade psíquica. Em Freud, S. Edição standard brasileira das obras psicológicas completas de Sigmund Freud. (Vol. 22, pp.63-84). Rio de Janeiro: Imago. (Obra original publicada em 1933[1932]).

Gagnebin, M. J. (2005). Sete aulas sobre linguagem, memória e história. Rio de Janeiro: Imago.

Gallano, C. (2008). El "sin tiempo" de la histeria hipermoderna. Em Os tempos do sujeito do inconsciente - A psicanálise no seu tempo e o tempo na psicanálise. V Encontro Internacional da IF - Escola de Psicanálise dos Fóruns do Campo Lacaniano (pp.91-94), São Paulo.

Giddens, A. (1991). As consequências da modernidade. (R. Fiker, Trad.). São Paulo: Editora Unesp.

Glezer, R. (1991). Tempo e os homens: Dom, servidor e senhor. Em Matienzo, A. J. História em Debate. XVI Simpósio Nacional de História da Associação Nacional dos Professores de História (pp.258-268), Rio de Janeiro.

Gramsci, A. (2011). Cartas do cárcere (antologia). (C. Diegues, Trad.). Santiago de Compostela: Estaleiro Editora.

Heidegger, M. (2005). Ser e tempo. (M. S. C. Schuback, Trad.). Petrópolis: Editora Vozes. (Obra original publicada em 1927).

Kehl, M. R. (2009). O Tempo e o cão: A atualidade das depressões. São Paulo: Boitempo.

Kundera, M. (2008). A insustentável leveza do ser. (T. B. de Carvalho, Trad.). São Paulo: Companhia das Letras.

Lima, A. M. (2008). Marcas estilísticas da temática do pensamento crítico na música “Admirável Chip Novo" de Pitty. Cadernos da Fucamp, 7(7), 63-72.

Lombardi, G. (2008) O manejo do tempo. (A. L. P. Pacheco, Trad.). Em Os tempos do sujeito do inconsciente - A psicanálise no seu tempo e o tempo na psicanálise. $\mathrm{V}$ Encontro 
Internacional da IF - Escola de Psicanálise dos Fóruns do Campo Lacaniano (pp.19-20), São Paulo.

Marx, K. (2007). Miséria da filosofia. (T. Guimarães, Trad.). São Paulo: Martin Claret. (Obra original publicada em 1847).

Mészáros, I. (2007). O desafio e o fardo do tempo histórico: O socialismo no século XXI. (A. Cotrim \& V. Cotrim, Trad.). São Paulo: Boitempo.

Mezan, R. (1998). Tempo de muda: Ensaios de psicanálise. São Paulo: Companhia das Letras. Migdalek, S. (2008). El aburrimiento, una forma del tiempo. Em Os tempos do sujeito do inconsciente - A psicanálise no seu tempo e o tempo na psicanálise. V Encontro Internacional da IF - Escola de Psicanálise dos Fóruns do Campo Lacaniano (pp.109-112), São Paulo.

Morin, E. (2005). Cultura de massas no século XX (O espírito do tempo - Neurose). (9 ed., Vol. I). Forense Universitária: São Paulo. (Obra original publicada em 1969).

Morin, E. (2009). Cultura de massas no século XX (O espírito do tempo - Necrose). (4 ed., Vol. II). Forense-Universitária: São Paulo. (Obra original publicada em 1977).

Newton, I. (1990). Principia: princípios matemáticos de filosofia natural. (Vol. I). (T. Ricci et al., Trad.). São Paulo: Nova Stella/EDUSP. (Obra original publicada em 1687).

Nietzsche, F. (1992). O nascimento da tragédia ou helenismo e pessimismo. (2 ed.). (J. Guinsburg, Trad.). São Paulo: Companhia das Letras. (Obra original publicada em 1886).

Nietzsche, F. (2011). Assim falou Zaratustra: Um livro para todos e para ninguém. (P. C. de Souza, Trad.). São Paulo: Companhia das Letras. (Obra original publicada em 1883).

Oliva-Augusto, M. H. (1995). O moderno e o contemporâneo: Reflexões sobre os conceitos de indivíduo, tempo e morte. Tempo Social. Rev. Sociol, 6(1-2), 91-105.

Panes, R. (2014). Little Giant. Little Giant [CD]. Londres: CRC Music Group. Pitty. (2003a). Admirável Chip Novo. Admirável Chip Novo [CD]. Rio de Janeiro: Deckdisc. Pitty. (2003b). Emboscada. Admirável Chip Novo [CD]. Rio de Janeiro: Deckdisc. 
Pitty. (2003c). Semana que Vem. Admirável Chip Novo [CD]. Rio de Janeiro: Deckdisc. Pitty. (2003d). Temporal. Admirável Chip Novo [CD]. Rio de Janeiro: Deckdisc.

Pitty. (2003e). Teto de Vidro. Admirável Chip Novo [CD]. Rio de Janeiro: Deckdisc.

Pitty. (2005a). A Saideira. Anacrônico [CD]. Rio de Janeiro: Deckdisc.

Pitty. (2005b). Guerreiros São Guerreiros. Anacrônico [CD]. Rio de Janeiro: Deckdisc.

Pitty. (2005c). Querer Depois. Anacrônico [CD]. Rio de Janeiro: Deckdisc.

Pitty. (2009a). Água Contida. Chiaroscuro [CD]. Rio de Janeiro: Deckdisc.

Pitty. (2009b). Só Agora. Chiaroscuro [CD]. Rio de Janeiro: Deckdisc.

Pitty. (2014a). Pitty: Cronografia: Uma trajetória em fotos. São Paulo: Edições Ideal.

Pitty. (2014b). Pouco. Setevidas [CD]. Rio de Janeiro: Deckdisc.

Pitty. (2014c). Serpente. Setevidas [CD]. Rio de Janeiro: Deckdisc.

Pitty. (2014d). Setevidas. Setevidas [CD]. Rio de Janeiro: Deckdisc.

Pitty; Duda; Joe; Martin. (2009a). 8 ou 80. Chiaroscuro [CD]. Rio de Janeiro: Deckdisc.

Pitty; Duda; Joe; Martin. (2009b). Rato na Roda. Chiaroscuro [CD]. Rio de Janeiro: Deckdisc.

Pitty; Duda; Martin; Guilherme. (2014). Olho Calmo. Setevidas [CD]. Rio de Janeiro:

Deckdisc.

Pitty; Martin. (2009). A Sombra. Chiaroscuro [CD]. Rio de Janeiro: Deckdisc.

Pitty; Martin. (2011). Dançando. Agridoce [CD]. Rio de Janeiro: Deckdisc.

Pitty; Martin. (2014a). Boca Aberta. Setevidas [CD]. Rio de Janeiro: Deckdisc.

Pitty; Martin. (2014b). Deixa Ela Entrar. Setevidas [CD]. Rio de Janeiro: Deckdisc.

Pitty; Martin. (2014c). Pequena Morte. Setevidas [CD]. Rio de Janeiro: Deckdisc.

Pitty; Peu Sousa. (2003). Equalize. Admirável Chip Novo [CD]. Rio de Janeiro: Deckdisc.

Pitty; Peu Sousa. (2005). Déjà Vu. Anacrônico [CD]. Rio de Janeiro: Deckdisc.

Russo, R. (1986). Tempo Perdido. Dois [CD]. Rio de Janeiro: EMI. 
Salum, L. K. P. (2009). Em busca do tempo. Freud, Lacan e Proust. Interpenetrações entre psicanálise e literatura. (Dissertação de Mestrado, Universidade de Brasília, Brasília, Brasil). Santos Neto, A. B. dos. (2013). Trabalho e tempo de trabalho na perspectiva Marxiana. São Paulo: Instituto Lukács.

Sater, A.; Teixeira, R. (1990). Tocando em Frente. (Gravada por Maria Bethânia). 25 Anos [CD]. Rio de Janeiro: Polygram Discos.

Sêneca, L.A. (2013). (L. S. Rebello, E. I. N. Vranas \& G. N. Macedo, Trad.). Sobre a brevidade da vida. Porto Alegre: L\&PM.

Soler, C. (2008). Atualidade. (S. Sobreira, Trad.). Em Os tempos do sujeito do inconscienteA psicanálise no seu tempo e o tempo na psicanálise. V Encontro Internacional da IF - Escola de Psicanálise dos Fóruns do Campo Lacaniano (pp.06-08), São Paulo.

Sousa, W. J. (2012). As marcas estilísticas na música Admirável Chip Novo. Em Ciência, tecnologia e inovação: Ações sustentáveis no desenvolvimento das regiões norte e nordeste. VII CONNEPI - Congresso Norte-Nordeste de Pesquisa e Inovação do Instituto Federal do Tocantins, Palmas.

Taylor, C. (2005). As fontes do self: A construção da identidade moderna. (2 ed.). (A. U. Sobral \& D. de A. Azevedo, Trad.). São Paulo: Edições Loyola. (Obra original publicada em 1989). Teixeira, A. (2008). Modulação pulsional do tempo. Em Os tempos do sujeito do inconsciente - A psicanálise no seu tempo e o tempo na psicanálise. V Encontro Internacional da IF - Escola de Psicanálise dos Fóruns do Campo Lacaniano (pp.105-108), São Paulo.

Vandré, G. (1968). Pra Não Dizer que Não Falei das Flores. Enciclopédia Musical Brasileira [CD]. Rio de Janeiro: Warner Music Brasil. (2000).

Veloso, C. (1979). Oração ao Tempo. Cinema Transcendental [LP]. Verve Records. 
Vital, E. G. L.; Queiroz, R. (2009). O anacronismo do “Admirável Mundo Novo" de Pitty: A crise de sentido do homem neobarroco. Em IV Colóquio Internacional Cidadania Cultural: diálogos de gerações. Editora EDUEPB, Campina Grande. 
ANEXOS

ANEXO I - Músicas de Pitty utilizadas nos subtítulos e citações

\section{Passos}

"Da janela ao corredor: 20 passos/Um cigarro, a mesma cor/Um dia pra gastar/Tantas portas pra fechar/Lavar o cheiro e o gosto/Foi sem hora pra voltar/Feche os olhos quando eu for mostrar/O meu mundo pra você que está sempre aqui/Em tudo o que existe ao meu redor”.

Disponível em: https://www.youtube.com/watch?v=BXCt9i9fh5o

\section{8 ou 80}

“Todo mundo tem segredo/Que não conta nem pra si mesmo/Todo mundo tem receio/Do que vê diante do espelho/Eu só quero o começo/Me entedia lidar com o meio/Quero muito, tenho apego/Já não quero e só resta desprezo/Nem sempre ando entre os meus iguais/Nem sempre faço coisas legais/Me dou bem com os inocentes/Mas com os culpados me divirto mais/Todo mundo tem segredo/Que não conta nem pra si mesmo/Todo mundo tem receio/Do que vê diante do espelho/Todo mundo tem desejo/Que não divide nem com o travesseiro/Um remédio pra amargura/Ou as drogas que vêm com bula/Nem sempre ando entre os meus iguais/Nem sempre faço coisas legais/Me dou bem com os inocentes/Mas com os culpados me divirto mais/Não conheço o que existe entre o 8 e o 80 ”.

Disponível em: https://www.youtube.com/watch?v=v5-JiSBfckQ

\section{A Saideira}

“Ei, não vá ainda embora/Beba mais um copo/É que logo agora vai começar a história/Se sente na pele que chegou a hora/Saber a qual é olhando no olho/Pra alguns isso assusta, mas é tão 
necessário/Pra ter uma noção do que é real/Pra se ter uma noção do que é real/Mas, ei, não vão ainda embora/Beba mais um copo/É que logo agora, já começou a história/Ei, não, não vá ainda embora/Beba mais um copo/É que logo agora, já começou a história/Mais um copo quase quente/Pra pessoas um tanto frias/Tão frias, tão frias, tão frias...”.

Disponível em: https://www.youtube.com/watch?v=-qoN2noP fE

\section{A Sombra}

"Pra que dissimular?/Se ela me segue aonde quer que eu vá/Melhor encarar/E aprender com ela a caminhar/Não vou mais negar/Por todo caminho minha sombra está/Eu quero saber me querer/Com toda beleza e abominação/Que há em mim/Isso nunca se desfaz/Enquanto há desejo não há paz/Eu quero saber me querer/Com toda beleza e abominação/Que há em mim”. Disponível em: https://www.youtube.com/watch?v=P3WCFHRjCXY

\section{Admirável Chip Novo}

"Pane no sistema, alguém me desconfigurou/Aonde estão meus olhos de robô?/Eu não sabia, eu não tinha percebido/Eu sempre achei que era vivo/Parafuso e fluido em lugar de articulação/Até achava que aqui batia um coração/Nada é orgânico, é tudo programado/E eu achando que tinha me libertado.../Mas lá vêm eles novamente e eu sei o que vão fazer:/Reinstalar o sistema/Pense, fale, compre, beba/Leia, vote, não se esqueça/Use, seja, ouça, diga/Tenha, more, gaste, viva/Não sinhô, sim sinhô, não sinhô, sim sinhô...”.

Disponível em: https://www.youtube.com/watch?v=lGz-idtX_rk

\section{Água Contida}

"Eu, chorando/Com essa cara toda amassada/Com esse olho em carne viva, retalhada/E esse nariz que não para de escorrer/Eu, chorando/Tão previsível quanto areia no deserto/Mais 
patético sem ninguém por perto/Tão imenso que não dá mais pra conter/Então sai, deixa correr/Toda a água contida/Então sai, deixa correr/Toda mágoa velada é água parada/E uma hora transborda/Você pode não entender se às vezes fico pelos cantos/Um tanto quieta, recolhida, mergulhada no meu pranto/É que ele me liberta na hora/No momento em que eu boto pra fora/O que já não me serve vai embora/E assim, eu fico leve”.

Disponível em: https://www.youtube.com/watch?v=5P6MPF2850g

\section{Anacrônico}

"É claro que somos as mesmas pessoas/Mas pare e perceba como o seu dia-a-dia mudou/Mudaram os horários, hábitos, lugares/Inclusive as pessoas ao redor/São outros rostos, outras vozes/Interagindo e modificando você/E aí surgem novos valores/Vindos de outras vontades/Alguns caindo por terra pra outros poderem crescer/Caem um, dois, três, caem quatro/A Terra girando não se pode parar/Outras situações em outras circunstâncias/Entre uma e outra, às vezes se vêem os mesmos defeitos/Todas aquelas marcas do jeito de cada um/Alguns ainda caem por terra pra outros poderem crescer/Outro ciclo/Em diferentes fases/Vivendo de outra forma/Com outros interesses/Outras ambições/Mais fortes, somadas com as anteriores/Mudança de prioridades/Mudança de direção/Alguns ainda caem por terra pra outros poderem crescer".

Disponível em: https://www.youtube.com/watch?v=r21T2BkFUio

\section{Boca Aberta}

"êta, alma - buraco sem fundo/que se vive tentando preencher/com deuses, com terapia/cartão de crédito, academia/um trago, carros velozes/carinhos fugazes, manhãs atrozes/em incríveis e intermináveis noites/da mais besta e vã alegria/e é sempre essa boca aberta, tragando tudo pelo caminho/de tudo o que se aproveita/de tudo só quero o agora/amanhã, acordo e resmungo:/‘eu 
quero minha vida de volta'/êta, alma - buraco sem fundo/que se vive tentando preencher/com corpos, com copos, com credos/amigos ternos, amores cegos/com beleza ou poesia/aquela penumbra que anuncia o dia/e faz o ontem deixar de ser/e é sempre essa boca aberta, tragando tudo pelo caminho".

Disponível em: https://www.youtube.com/watch?v=lddhA3HitVs

\section{Dançando}

"Eu sei que lá no fundo há tanta beleza no mundo/Eu só queria enxergar/As tardes de domingo, o dia me sorrindo/Eu só queria enxergar/Qualquer coisa pra domar o peito em fogo/Algo pra justificar uma vida morna/O mundo acaba hoje e eu estarei dançando/Com você/Não esqueço aquela esquina, a graça da menina/Eu só queria enxergar/Por isso eu me entrego a um imediatismo cego/Pronta pro mundo acabar/Você acredita no depois? Prefiro o agora/Se no fim formos só nós dois, que seja lá fora/O mundo acaba hoje e eu estarei dançando/Com você”. Disponível em: https://www.youtube.com/watch?v=w5Gf1ocKxzM

\section{Deixa Ela Entrar}

"se a falta aflorar/e você vir como eu sou ruim/ainda vai gostar de mim?/é toda torta a sensação/de que o caminho é/se encontrar na perdição/entenda que/eu não sei onde isso vai parar/também não sei/por quê insisto em prorrogar.../essa voz sem palavras/me dizendo sim e não/quem sabe é tábua de salvação?/e toda vez é a velha questão/de nunca saber o que se vai amar amanhã/e mesmo assim, escolher/mas quer saber? já cansei de racionalizar/eu sei, é um clichê que eu dissequei/só pra vê-lo murchar/e se a sorte aparecer, deixa ela entrar/me coloco à sua mercê, e deixo ela entrar/pela fresta que se abriu: deixa ela entrar!/antes hoje do que nunca mais".

Disponível em: https://www.youtube.com/watch?v=P60pGOZ9dTY 


\section{Déjà Vu}

"Nenhuma verdade me machuca/Nenhum motivo me corrói/Até se eu ficar só na vontade, já não dói/Nenhuma doutrina me convence/Nenhuma resposta me satisfaz/Nem mesmo o tédio me surpreende mais/Mas eu sinto que eu tô viva/A cada banho de chuva/Que chega molhando o meu corpo/Nenhum sofrimento me comove/Nenhum programa me distrai/Eu ouvi promessas e isso não me atrai/E não há razão que me governe/Nenhuma lei pra me guiar/Eu tô exatamente aonde eu queria estar/A minha alma nem me lembro mais/Em que esquina se perdeu/Ou em que mundo se enfiou/Mas já faz algum tempo/[Mas eu não tenho pressa]”.

Disponível em: https://www.youtube.com/watch?v=i0FJNsbgqjc

\section{Do Mesmo Lado}

“Quem chegou a ouvir o som?/Quem ligou se tá no tom?/Quem não viu e mesmo assim falou?/Quem tomou e não gostou?/Quem dividiu o tudo em dois?/Quem preferiu deixar pra depois?/Quem escolheu o bem e o mal?/Quem achou que tudo é normal?/E eu tô do mesmo lado que você/E eu tô no mesmo barco que você/Então, pensa, ouve e vive a música/Quem chegou a ouvir o som?/Quem ligou se tá no tom?/Quem não viu e mesmo assim falou?/Quem tomou e não gostou?/Quem partiu a Terra ao meio?/Quem decidiu o que era feio?/Quem acreditou no ‘tudo bem'?/Quem confiou em alguém?/E eu tô do mesmo lado que você/E eu tô no mesmo barco que você/Então, pensa, ouve e vive a música".

Disponível em: https://www.youtube.com/watch?v=w00n3V9JZFg

\section{Emboscada}

"Pra quê me dizer, se não é capaz?/Te pego na saída e vamo vê quem vai ficar/Pra quê me dizer, se não é capaz?/Te pego na saída e vamo vê quem vai ganhar/Quem vai ganhar?/Reze 
suas preces e não conte com ninguém/Veja tudo como se não houvesse amanhã porque/Parece um dia tão normal/Mas em cada esquina você pode vacilar, e então/Vê se se cuida, rapaz/Então, estamos quase quites/Se ainda não percebeu, isso é uma/Emboscada, armadilha/Emboscada, armadilha/Se cada ação traz junto uma reação/Você sabia que essa hora ia chegar e/Ainda assim se escondeu/E eu, cada vez mais perto, esse jogo é meu/E então é xeque-mate, rapaz/Então, fim de festa pra você/Se ainda não percebeu, isso é uma/Emboscada, armadilha/Emboscada, armadilha/Reze suas preces e não conte com ninguém/Veja tudo como se não houvesse amanhã".

Disponível em: https://www.youtube.com/watch?v=srPoXQ2Iywo

\section{Epílogos}

"Primeiro os aniversários/As festas, balões coloridos/Bailes de debutante/As noites em claro/Depois os casamentos/Amores e nascimentos/Por fim, os funerais/As camas de hospitais/Não me leve agora/Eu não quero ir embora/Tenho tanto o que fazer/Tenho um filho pra ter/Tenho motivos pra crer/Que ainda não é hora/Todos rumo ao acaso/Sem nunca ter escolhido/Não é questão de sorte/É jogo vencido".

Disponível em: https://www.youtube.com/watch?v=NaehQGE11bE

\section{Equalize}

“Às vezes, se eu me distraio/Se eu não me vigio um instante/Me transporto pra perto de você/Já vi que não posso ficar tão solta/Me vem logo aquele cheiro/Que passa de você pra mim/Num fluxo perfeito/E enquanto você conversa e me beija/Ao mesmo tempo eu vejo/As suas cores no seu olho, tão de perto/Me balanço devagar, como quando você me embala/O ritmo rola fácil, parece que foi ensaiado/E eu acho que eu gosto mesmo de você/Bem do jeito que você é/Eu vou equalizar você/Numa frequência que só a gente sabe/Eu te transformei nessa canção/Pra 
poder te gravar em mim/Adoro essa sua cara de sono/E o timbre da sua voz/Que fica me dizendo coisas tão malucas/E que quase me mata de rir/Quando tenta me convencer/Que eu só fiquei aqui/Porque nós dois somos iguais/Até parece que você já tinha/O meu Manual de Instruções/Porque você decifra os meus sonhos/Porque você sabe o que eu gosto/E porque, quando você me abraça, o mundo gira devagar/E o tempo é só meu e ninguém registra a cena/De repente vira um filme, todo em câmera lenta/E eu acho que eu gosto mesmo de você/Bem do jeito que você é/Eu vou equalizar você/Numa frequência que só a gente sabe/Eu te transformei nessa canção/Pra poder te gravar em mim”.

Disponível em: https://www.youtube.com/watch?v=wKRpQ4uZFhY

\section{Guerreiros São Guerreiros}

"Sou guerreiro/Eu não vim aqui pra pedir/O que eu quero eu vou conquistar/Se agora é hora de ir/Tô na estrada, sigo em frente/Eu não penso em fugir/E nem mesmo me consolar/Tenho medos e mesmo assim/Tô na estrada, sigo em frente/Sou guerreiro/Enquanto eu tiver chão sob os pés/Enquanto eu puder caminhar/Enquanto eu puder estar viva/Enquanto minha hora não chegar/Talvez eu não vença o tempo todo/E ainda posso até cair/Só quero manter minha alma forte/Erguer a cabeça e seguir/Sou guerreiro".

Disponível em: https://www.youtube.com/watch?v=gZYbPZgYjus

\section{Olho Calmo}

"nem pensava que/essa hora ia chegar/saber não insistir/nessa história de se gastar/e depois do rancor, respirar/vigiar ao redor, e respirar/o traquejo de esperar/a hora certa de esbravejar/fumegando de vazio e pó/gozo sozinho, sem dó, sem nada/e depois do rancor, respirar/vigiar ao redor, e respirar/aprender a usar o olho calmo/(do cão que já nem ladra mais, só morde)". 
Disponível em: https://www.youtube.com/watch?v=OnXzEWmzTcM

\section{Pequena Morte}

"gosto o jeito que você se despe dos costumes/o jeito que assume que o negócio é se arriscar/eu tinha prometido não ceder à compulsão/mas é uma agressão dizer pra um bicho não caçar/o bom é que/depois, o final é a pequena morte lenta de nós dois/e do nada a sua mão ocupa a minha cintura/fica uma quentura demarcando o lugar/o seu olho jura, e eu já saquei que essa noite/de um jeito ou de outro a gente vai se entrelaçar/o bom é que/depois, o final é a pequena morte lenta de nós dois/desagradável não te ver por aí/insuportável não te ter por aqui/ainda outro dia eu tentei com alguém/e o que eu queria era colar em você, meu bem/de repente a gente nessa dança muito doida/rolando, suando, nunca para de pulsar/lá se vão as horas, ninguém conta mais o tempo/o arrebatamento não demora a chegar/desagradável não te ver por aí/insuportável não te ter por aqui/ainda outro dia eu tentei com alguém/e o que eu queria era colar em você,/pular em você,/subir em você,/meu bem".

Disponível em: https://www.youtube.com/watch?v=U69mASkEkws

\section{Pouco}

“vivo/tentando/domar/meu mundo/nunca/consigo/saber/sigo/tentando/sair/do fundo/nado,/não quero/morrer/quanto/mais perto/mais longe/do certo/corro/nessa/direção/não/espere/que eu/me contente com pouco/é pouco, é pouco, tão pouco/dor exposta é pra doer/tão mais fácil se entorpecer/oscilando no eterno vir-a-ser/resistindo a me dissolver".

Disponível em: https://www.youtube.com/watch?v=0f7N45jxjJc

\section{Querer Depois}


“...e depois, então,/que conquistar o último desafio/quando aprender a voar/quando achar que já tem tudo/o que vai querer depois?”.

Disponível em: https://www.youtube.com/watch?v=ZdeCe2T_1JA

\section{Rato na Roda}

“Tenho pressa, eu vou correr/Sempre há muito o que fazer/Nem parece o mesmo lugar/Minha adorável gaiola dourada/E se for? E se for?/Agradeço pela ração/Aqui tudo está sempre à mão/Um cantinho pra eu me deitar/Uma bola pra me acalmar/E se for? E se for?/Sempre correndo mais e mais e mais e mais e mais.../Vê? É simples/Eu nem me importo mais/Sempre seguindo/Pra nunca chegar/O coelho dizendo 'já é tarde'/Intensifica a ansiedade/Vidros, quartos impessoais/Cordões de isolamento e tudo mais/E se for? E se for?/ - 'Te cuido tanto aqui, te dou o que quiser/É só me divertir e não tentar fugir...'/Sempre correndo mais e mais e mais e mais e mais.../Vê? É simples/Eu nem me importo mais/Sempre seguindo/Pra nunca chegar".

Disponível em: https://www.youtube.com/watch?v=_6SDxJ6EobQ

\section{Semana que Vem}

“Amanhã eu vou revelar/Depois eu penso em aprender/Daqui a uns dias eu vou dizer/O que me faz querer gritar/No mês que vem tudo vai melhorar/Só mais alguns anos e o mundo vai mudar/Ainda temos tempo até tudo explodir/Quem sabe quanto vai durar/Não deixe nada pra depois, não deixe o tempo passar/Não deixe nada pra semana que vem/Porque semana que vem pode nem chegar/A partir de amanhã eu vou discutir/Da próxima vez eu vou questionar/Na segunda eu começo a agir/Só mais duas horas pra eu decidir/Não deixe nada pra depois, não deixe o tempo passar/Não deixe nada pra semana que vem/Porque semana que vem pode nem chegar/Esse pode ser o último dia de nossas vidas/Última chance de fazer tudo ter valido a 
pena/Diga sempre tudo o que precisa dizer/Arrisque mais pra não se arrepender/Nós não temos todo o tempo do mundo/E esse mundo já faz muito tempo/O futuro é o presente, e o presente já passou/Nada pra depois, não deixe o tempo passar/Não deixe nada pra semana que vem/Porque semana que vem pode nem chegar".

Disponível em: https://www.youtube.com/watch?v=99e8LkF8EUY

\section{Serpente}

“um presságio,/eu vi também/arrastou o céu numa conjuração/corpos ébrios/em confusão/a sustentação é que a manhã já vem/logo mais amanhã já vem/o acaso/empurra quem/se agarra à borda/preso em negação/solitário/na multidão/a sustentação é que a manhã já vem/logo mais amanhã já vem/chega dessa pele, é hora de trocar/por baixo ainda é serpente/e devora a cauda pra recomeçar/pelo fogo:/transmutação/sem afago, lapidando o aprendiz/o que sobre é cicatriz/a sustentação é que a manhã já vem/logo mais amanhã já vem/chega dessa pele, é hora de trocar/por baixo ainda é serpente/e devora a cauda pra continuar...”.

Disponível em: https://www.youtube.com/watch?v=u3S1r785sIg

\section{Setevidas}

“só nos últimos cinco meses/eu já morri umas quatro vezes/ainda me restam três vidas pra gastar/era um mar vermelho/me arrastando do quarto pro banheiro/pupila congelada/já não sabia mais de nada/é besta assim esse quase-morrer/desconcertante perceber/que as coisas são, e tudo floresce a despeito de nós/pálido, doente/rendido, decadente/viver parece mesmo coisa de insistente/a postura é combativa; ainda tô aqui, viva/um pouco mais triste, mas muito mais forte/e agora que eu voltei, quero ver me aguentar/a caixa de sombra se abriu/foi um maremoto atrás do outro/ferro na jugular/tirando tudo do lugar/se coisa ruim faz a gente crescer - e todo esse clichê/já nem caibo mais na casa/não caibo mais aqui”. 
Disponível em: https://www.youtube.com/watch?v=QgHnzDBV4Ps

\section{Só Agora}

"Babe, tanto a aprender/Meu colo alimenta a você e a mim/Deixa eu mimar você, adorar você/Agora, só agora/Porque um dia, eu sei/Vou ter que deixá-lo ir/Sabe, serei seu lar se quiser/Sem pressa, do jeito que tem que ser/Que mais posso fazer? - Só te olhar dormir/Agora, só agora/Correndo pelo campo/Antes de deixá-lo ir/Muda a estação/Necessário e são/Você a florescer/Calmamente, lindamente/Mesmo quando eu não mais estiver/Lembre que me ouviu dizer/O quanto me importei, e o que eu senti/Agora, só agora talvez você perceba/Que eu nunca vou deixá-lo ir".

Disponível em: https://www.youtube.com/watch?v=NI_2q7awqE8

\section{Só de Passagem}

"Eu não sou o meu carro/Eu não sou meu cabelo/Esse nome não sou eu/Muito menos esse corpo/Não tenho cor nem cheiro/Não pertenço a lugar algum/Eu posso ir e vir como eu quero/Nada me toca nem aprisiona/Vou pairando leve, leve.../Acima da carne e do metal/Eu possuo muitas coisas/E nada disso me possui/Eu não sou a comida que eu como/Não sou a roupa que eu visto/Não espere por uma resposta/Porque eu não tenho explicação/Eu não sou a minha casa/Não faço parte da minha rua/Vou pairando leve, leve.../Acima da carne e do metal/Eu possuo muitas coisas/E nada disso me possui/Espíritos são livres, espíritos passeiam por aqui/Espíritos são livres, espíritos só passam por aqui”.

Disponível em: https://www.youtube.com/watch?v=ENoUB5HL1e4

\section{Temporal}


“Chega simples como um temporal/Parecia que ia durar/Tantas placas e tantos sinais/Já não sei por onde caminhar/E quando olhei no espelho/Eu vi meu rosto e já não reconheci/E então vi minha história/Tão clara em cada marca que tava ali/Se o tempo hoje vai depressa/Não tá em minhas mãos/Cada minuto me interessa/Me resolvendo ou não/Quero uma fermata que possa fazer/Agora o tempo me obedecer/E só então, eu deixo/Os medos e as armas pra trás”.

Disponível em: https://www.youtube.com/watch?v=NdJQUiHY1R4

\section{Teto de Vidro}

"Quem não tem teto de vidro/Que atire a primeira pedra/Andei por tantas ruas e lugares/Passei observando quase tudo/Mudei, o mundo gira num segundo/Busquei dentro de mim os meus lares/E aí, tantas pessoas querendo sentir/Sangue correndo na veia/É bom assim, se movimenta e está vivo/Ouvi milhões de vozes gritando.../Eu quero ver quem é capaz/De fechar os olhos e descansar em paz/Quem não tem teto de vidro/Que atire a primeira pedra/Na frente está o alvo que se arrisca pela linha/Não é tão diferente do que eu já fui um dia/Se vai ficar, se vai passar, não sei/E num piscar de olhos, lembro o tanto que falei,/Deixei, calei/E até me importei/Mas não tem nada, eu tava mesmo errada/Cada um em seu casulo, em sua direção/Vendo de camarote a novela da vida alheia/Sugerindo soluções, discutindo relações/Bem certos que a verdade cabe na palma da mão/Mas isso não é uma questão de opinião/E isso é só uma questão de opinião".

Disponível em: https://www.youtube.com/watch?v=pFNNOmwc3vM 